\title{
Platinum Deposits of the Goodnews Bay District,
}

Alaska

By JOHN B. MERTIE, JR.

GEOLOGICAL SURVEY PROFESIONAL PAPER 938

Mining history and general and economic

geology of placer deposits of the district

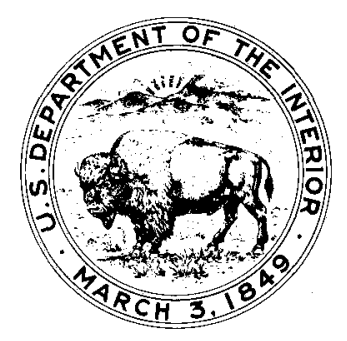

UNITED STATES GOVERNMENT PRINTING OFFICE, WASHINGTON：1976 


\title{
UNITED STATES DEPARTMENT OF THE INTERIOR
}

THOMAS S. KLEPPE, Secretary

\section{GEOLOGICAL SURVEY}

\author{
V. E. McKelvey, Director
}

Library of Congress Cataloging in Publication Data

Mertie, John Beaver, 1888-

Platinum deposits of the Goodnews Bay district, Alaska.

(Geological Survey Professional Paper 938)

Bibliography: p. 41-42.

Supt. of Docs. no.: I.19.16:938.

1. Platinum ores-Alaska-Goodnews Bay region. 2. Placer deposits-Alaska-Goodnews Bay region. I. Title. II. Series: United States Geological Survey Professional Paper 938.

TN490.P7M4 $553^{\prime} .422^{\circ} 097984$

76-2393

For sale by the Superintendent of Documents, U.S. Government Printing Office

Washington, D.C. 20402

Stock Number 024-001-02784-4 


\section{CONTENTS}

\begin{tabular}{|c|c|c|c|}
\hline & age & \multirow{2}{*}{\multicolumn{2}{|c|}{ Economic geology—Continued }} \\
\hline Abstract & 1 & & \\
\hline Introduction & 1 & Platinum placers & 22 \\
\hline Location of district & 1 & Analytical data & 22 \\
\hline Early and recent surveys & 1 & Sieve and chemical analyses & 23 \\
\hline Discovery, mining, and prospecting & 4 & Localities of placer deposits & 23 \\
\hline Acknowledgments & 5 & Tributaries of Salmon River & 23 \\
\hline Geography - - & 5 & Platinum Creek & 23 \\
\hline General geology & 10 & Fox Gulch and upper Platinum Creek & 23 \\
\hline Bedded rocks & 10 & Squirrel Creek & 24 \\
\hline Late Paleozoic(?) rocks & 10 & Lower Platinum Creek & 25 \\
\hline Lavas and tuffs & 10 & Last Chance, Boulder, and Dowry Creeks & 26 \\
\hline Intrusive rocks & 11 & Clara Creek & 26 \\
\hline Ultrabasic rocks & 11 & McCann Creek & 27 \\
\hline Unconsolidated deposits & 12 & Salmon River & 27 \\
\hline Geomorphology & 12 & Pay streak of valley floor & 28 \\
\hline Economic geology & 14 & Bench paystreak & 31 \\
\hline Platinum metals & 14 & Placer gold & 34 \\
\hline 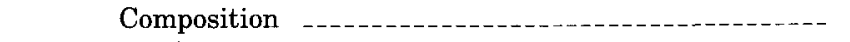 & 14 & Alluvial concentrates & 35 \\
\hline Analyses & 15 & Platinum lodes & 39 \\
\hline Impurities and dross & 16 & Selected references & 41 \\
\hline Special chemical investigations & 17 & & \\
\hline
\end{tabular}

\section{ILLUSTRATIONS}

1. Sketch map of part of southwestern Alaska showing location of Goodnews Bay district

2. Geologic map of the Goodnews Bay platinum district, Alaska

3. Sketch map of placer mining claims in the valley of Salmon River and its tributaries showing path of dredge along pay streaks

4-9. Photographs showing:

4. Panoramic view of west side of Susie Mountain and upper valley of Salmon River

5. Panoramic view of west side of Red Mountain ridge

6. Thorsen Mountain, the upper valley of Platinum Creek, and camp of Goodnews Bay Mining Co.

7. Camp of Goodnews Bay Mining Co. and the upper valley of Squirrel Creek

8. Low gravel terrace in lower valley of Salmon River extending from Happy Creek to Chagvan Bay -

9. Lower valley of Smalls River

10-14. Graphs showing:

10. Mean size of platinum grains by claims and production curve for pay streak of valley floor, Salmon River _- 29

11. Mean analyses of four platinum metals by claims and units for pay streaks of valley floor and bench, Salmon River

12. Mean size of platinum grains by units and production curve for bench pay streak, Salmon River

13. Gold production by claims and units for two pay streaks, Salmon River

14. Variation in composition of platinum metals from streams that drain Red Mountain ridge

\section{TABLES}

1. Chemical analyses of ultrabasic rocks, Red Mountain ridge

2. Chemical analysis of cation of cooperite

3. Electron microprobe analysis of osmiridium 
TABLE 4. Complete chemical analyses of two samples of platinum metals

5. Principal alloy for dredge cleanups of 1943

6. Osmiridium alloy for dredge cleanups of 1943

7. Principal alloy for dragline excavator cleanups of 1943

8. Osmiridium alloy for dragline excavator cleanups of 1943

9. Analysis of screened sample of platinum metals, Discovery claim, Salmon River

10. Screened sample of platinum metals, recomputed free of gold and impurities, Discovery claim, Salmon River _...- 20

11. Magnetic subfractions of fraction VIII _.........

12. Chemical data on subfraction VIII-g -

13. Computation of principal alloy, fraction VIII _

14. Percentages of platinum metals, gold, and impurities, Goodnews Bay district

15. Analyses of precious metals, Fox Gulch and upper Platinum Creek

16. Analyses of precious metals, Squirrel Creek ........

17. Analyses of precious metals, valley of Platinum Creek

18. Analyses of precious metals, Boulder and Dowry Creeks

19. Mean analyses of precious metals, Clara Creek

20. Comparison of platinum metals from streams on east flank of Red Mountain ridge

21. Mean sizes of platinum grains by claims, pay streak of valley floor, Salmon River

22. Mean values of platinum analyses by claims, pay streak of valley floor, Salmon River

23. Mean sizes of platinum grains by units, bench pay streak, Salmon River

24. Mean granularity of platinum metals in two pay streaks, valley of Salmon River

25. Mean values of platinum analyses by units, bench pay streak, Salmon River

26. Distribution of gold by claims and units two pay streaks, valley of Salmon River

27. Mean mineral content of alluvial concentrates 


\title{
PLATINUM DEPOSITS OF THE GOODNEWS BAY DISTRICT, ALASKA
}

\author{
By John B. Mertie, JR.
}

\section{ABSTRACT}

Platinum placers were discovered in 1926 in a small area south of Goodnews Bay, in southwestern Alaska. Beginning in 1927, the placers were worked for 7 years by small-scale mining methods; in later years dragline excavators and a dredge were utilized. These deposits are important, not only because they are of high grade but because they are the only commercial source of platinum metals in the United States.

The bedded rocks of this area are sedimentary and volcanic rocks of Iate Paleozoic(?) age that have been intruded by a variety of ultrabasic rocks. The platinum metals of the placers have been derived from a mass of dunite and related rocks that constitute the bedrock of Red Mountain in the upper valley of the Salmon River. The western headwater tributaries of this stream are the fluvial conduits that have produced all the placers in the valley of the river.

The principal placers lie in two pay streaks, one in the valley floor of the Salmon River and the other in an ancient stream channel along the east side of this valley. The stream-channel deposit, called the bench pay streak, was formed in early Pleistocene time; its alluvial materials consist largely of clay derived from an ancient moraine believed to be of Nebraskan age. The valley-floor deposit, called the pay streak of the valley floor, consists of alluvial materials of fluvial and glaciofluvial origin whose ages range from Yarmouth to Holocene. Both channels contain high-grade placers that have yielded a large volume of platinum metals.

The platinum metals of these deposits are contained mainly in two alloys intergrown in a pseudoeutectic fabric. The major alloy is mainly platinum, with a small amount of iridium, still smaller amounts of rhodium and palladium, and probably some osmium and ruthenium. The minor alloy is dominantly iridium and osmium with less platinum and still less ruthenium and rhodium. The compositions of these two alloys are somewhat variable but tend to approach constant mean values. A small amount of free gold is recovered with the platinum metals. In addition to these two alloys, minute amounts of five platinum minerals have been identified. The weighted mean percentages of platinum, iridium, osmium, ruthenium, rhodium, palladium, and gold, as mined from 1936 to 1972 , are respectively $82.25,11.32,2.15,0.17,1.30,0.38$, and 2.43 .

The lodes from which these placers have been derived are, or have been, localized in the Red Mountain ridge, where the principal rocks are dunite and serpentinite. No lodes have been recognized, either because the platinum metals are sparsely distributed or because a large part of the platiniferous rock has been eroded. It is known, however, that the amounts of iridium, osmium, and ruthenium, or of osmiridium, decrease from south to north. Other generalizations regarding the composition and granularity of these metals have been deduced. The size and shape of the platinum lodes may have ranged from diffuse disseminations to high-grade concentrations in small loci. Under certain assumptions, the tenor of platinum metals in the dunite can be roughly approximated. Utilizing two totally different methods of computation, the mean tenor has been estimated to lie between 0.19 and 0.27 grain of platinum metals per cubic yard of dunite, or 0.014 to 0.023 gram per stere. No large low-grade deposits of commercial value are likely to be found, but it is possible that some small high-grade concentrations occur.

\section{INTRODUCTION}

\section{LOCATION OF DISTRICT}

Goodnews Bay is an inlet from Bering Sea on the west coast of Alaska, about 180 miles northwest of the Alaska Peninsula and about 100 miles south of the mouth of the Kuskokwim River (fig. 1). The Goodnews Bay platinum district is bounded on the west by Kuskokwim Bay, on the north by Goodnews Bay, and on the east and south by the Kinegnak River and its tributaries (fig. 2). The geologic map (fig. 2) covers an area of about 242 square miles, lying approximately between lat $58^{\circ} 48^{\prime}$ and $59^{\circ} 03^{\prime} \mathrm{N}$. and long $161^{\circ} 32^{\prime}$ and $161^{\circ} 55^{\prime} \mathrm{W}$. This map is essentially the same as that published in U.S. Geological Survey Bulletin 918 but is assembled on a new base having a scale of $1: 63,360$.

\section{EARLY AND RECENT SURVEYS}

The earliest exploration by the Geological Survey in this region was in 1898 under the leadership of Spurr (1900), who traversed the Kuskokwim River from its headwaters to its mouth and continued then up the Kanektok River, down the Togiak River, and eastward along the coast of the Alaska Peninsula. In 1919, an area north and northeast of Goodnews Bay was visited and mapped by a Geological Survey party who produced topographic and geologic maps on a scale of $1: 250,000$. The geology and mineral resources were described by Harrington (1921).

Interest in this district was revived in the twenties with the discovery of platinum placers south of Goodnews Bay, subsequently developed and mined. In 1937, the Geological Survey sent a topographic and geologic field party into the Goodnews Bay area to prepare maps and study the mineral deposits. A topographic map on a scale of 1:62,500 was prepared by FitzGerald and a geologic map was made by Mertie 


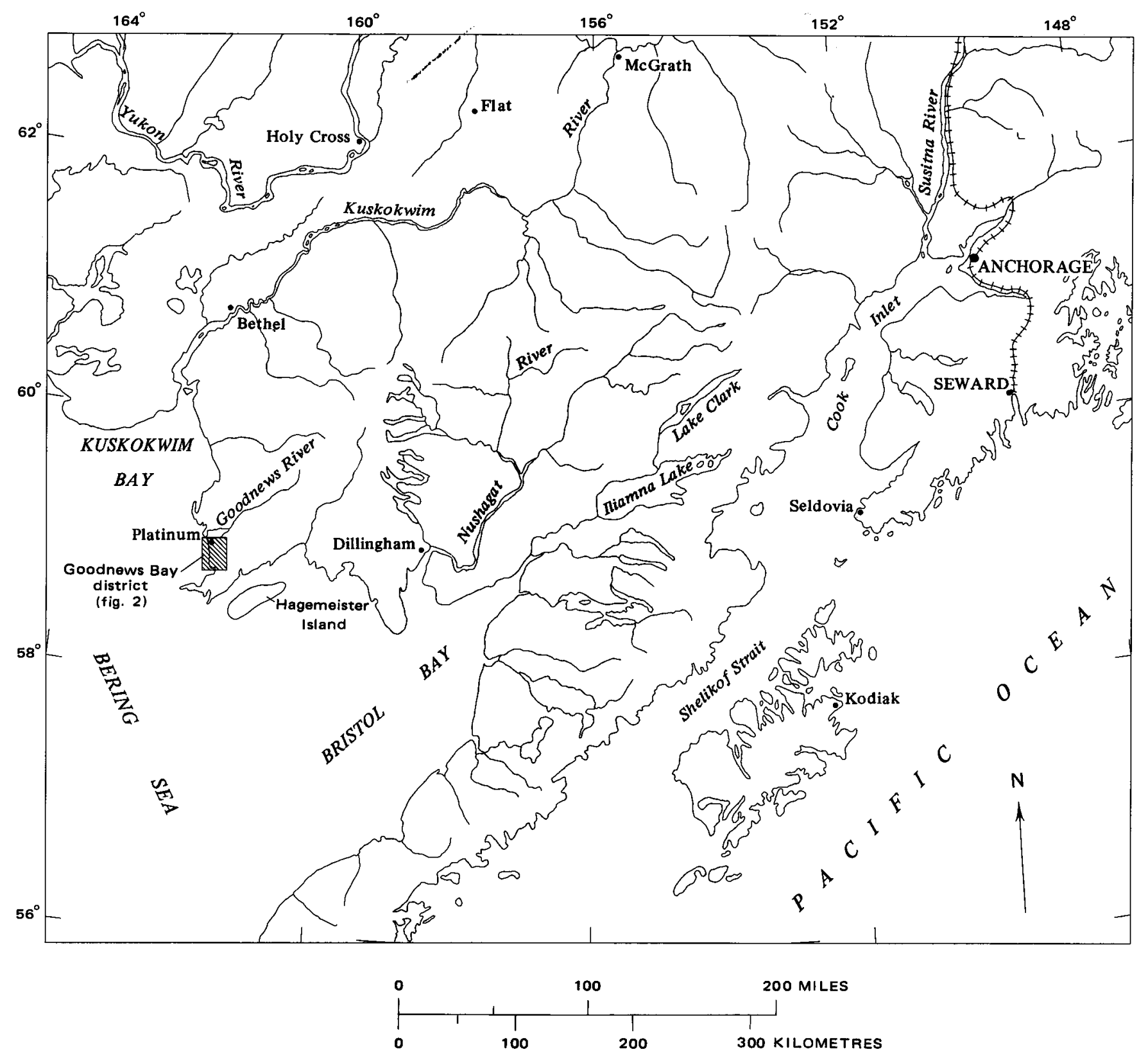

FIGURE 1.-Sketch map of part of southwestern Alaska showing location of Goodnews Bay district.

(1940a), who also described the general geology and placers and gave the character and composition of the platinum metals. Reconnaissance work was done in this region in 1946-53 by Hoare and Coonrad (1961a,b), who published geologic maps of the Hagemeister Island and Goodnews quadrangles on a scale of $1: 250,000$. The latest contribution to the geology of the Goodnews Bay district is a paper by Porter (1967) on the glacial history.

The dredge now operating in the valley of the Salmon River was being built when the fieldwork of 1937 was underway. Mining by the dredge and dragline excavators and concurrent underground exploration by drilling have produced much additional information on these platinum deposits. The mining and subsurface data of the report published in 1940 are now outdated and obsolete, although the geologic map and the descriptions of the geologic formations are still valid. In order to bring the economic data up to date, Mertie revisited this district in 1966, 1968, and 1969. The Goodnews Bay Mining Co. has cooperated by making 
INTRODUCTION

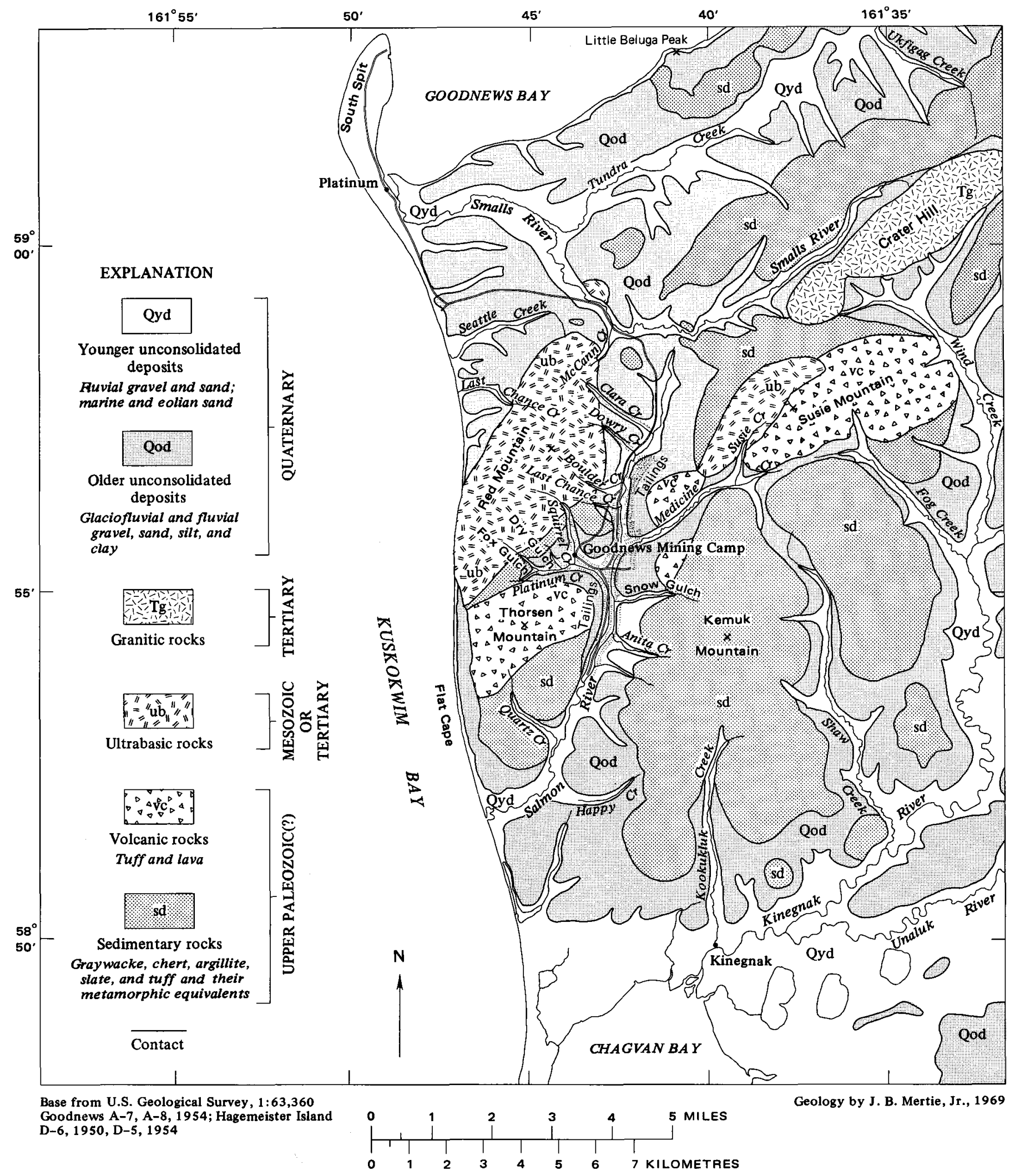

FiGURE 2.-Geologic map of the Goodnews Bay platinum district. 
available to the writer all the company's mining records since 1934 .

Small quantities of platinum metals have been recovered as a byproduct of gold placer mining at numerous places in Alaska; the Goodnews deposits are important because they are the only placers in Alaska or elsewhere in the United States that have been worked primarily for their content of the platinum metals. A small amount of gold has been recovered with the platinum metals. Chemical examination of the rocks from which the platinum is derived, as well as the concentrates recovered in placer mining, shows the presence in bedrock of chromium, copper, and nickel, but no commercial lodes of these elements or of the platinum metals have yet been found.

\section{DISCOVERY, MINING, AND PROSPECTING}

The history of the original discovery of platinum in the Goodnews Bay district, together with a sketch of earlier mining operations, is given by Reed (1933). According to his account, platinum was discovered in 1926 at the mouth of Fox Gulch, a tributary of Platinum Creek, by an Eskimo named Walter Smith. Thinking that the metal was "white gold," Smith related his discovery to another native called Henry. Whuya, who communicated this information to Charles Thorsen, a local resident and miner in this district for many years. Thorsen went to the site of the discovery, panned some of the metallic material, and sent it to the office of the U.S. Bureau of Mines at Fairbanks, where it was analyzed and determined to contain platinum. In 1928, Thorsen discovered platinum in the gravels of Clara Creek, and in the same year Edward St. Clair made the first discovery of platinum on Squirrel Creek.

The complete history of the early mining in this district has not been recorded, but small-scale mining plants are known to have been operated on Platinum, Squirrel, and Clara Creeks and on Fox and Dry Gulches intermittently from 1927 to 1934 . Numerous details of these operations have been recorded elsewhere (Reed, 1933) and will not be repeated here.

Most of the earlier mining was done in the headwaters of Platinum and Clara Creeks, where the ground was shallow enough for small-scale mining methods, such as ground sluicing and shoveling into sluice boxes. It soon became evident to the several small operators that although this was a promising field, mining would have to be done on a large scale to exploit the deeper deposits. Consequently, the many mining claims began to be consolidated and passed eventually into the control of two concerns, the Clara Creek Mining Co. and the Goodnews Bay Mining Co.

The Clara Creek Mining Co., the smaller of these two concerns, acquired ownership or leases to about 20 claims located mainly in the valley of Clara Creek and in the valley of the Salmon River between the mouths of Clara and Platinum Creeks. This company, using a dragline excavator, began in 1936 to work the east end of claim 1 above Discovery (1A), Clara Creek; they worked upstream until this pay streak was mined out. Thereafter they mined the pay streak of Dowry Creek, a small stream about half a mile south of Clara Creek. Some work was done on Dry Gulch, a tributary of Platinum Creek, but at the end of 1940 or 1941 all mining operations by this company were terminated.

The Goodnews Bay Mining Co. began work with a dragline excavator on Squirrel Creek in August 1934 and continued such mining for 7 years until most of the placers of Platinum Creek, Fox Gulch, and Squirrel Creek were worked out. Marginal ground remained, however, not worked at that time. Meanwhile, two pay streaks were found and staked in the valley of the Salmon River, one in the valley floor and the other along the eastern wall of the valley. The mining of these two pay streaks has been the principal activity in the Goodnews Bay Mining district.

The Goodnews Bay Mining Co. gradually acquired title to most of the claims staked in the valley floor and along the bench of the Salmon River, aggregating about 150 claims, and obtained leases on other claims that it did not own. All the mining claims on the Salmon River and its tributaries are shown on the sketch map of claims, figure 3. From 1942 to 1957, the Goodnews Bay Mining Co., starting on the Association bench claim opposite claim 9A, worked downstream on the bench with a dragline excavator. In 1937, however, the company built a dredge on the upper end of claim $1 \mathrm{~B}$, which has operated continuously since that time (Sawin, 1938). The path of the dredge from the date of its construction to the present time is shown on the claim map of figure 3 . From its original site, the dredge worked upstream to claim 1A, then turned, working downstream to claim 7B, where in 1942 it turned again and worked upstream to claim 6A. In 1947, it turned again and worked downstream to claim $2 \mathrm{~A}$ where in 1949 it moved eastward onto what is hereinafter designated as the bench pay streak. From the Ethel bench claim, the dredge moved sinuously but generally southward across the Palladium, Osmium, Ruthenium, Rhodium, Platinum, and Iridium bench claims to Discovery claim of Snow Gulch. From 1955 to 1963, it worked southward to the Olson bench claim where, even though 40 feet of overburden was being removed by a large dragline excavator, the alluvial cover became too thick for economic mining and the dredge moved westward to the pay streak of the valley floor. From claim $10 \mathrm{~B}$ the dredge worked upstream to the upper end `Claims are numbered above (A) or below (B) Discovery. 
of claim 8B, where in 1964 it turned and began working downstream. In 1966, at the lower end of claim 15B, the dredge turned again and continued upstream in a final cut to claim 5B. In 1972, it moved eastward to the bench pay streak, where it is now working old tailings and areas of unworked marginal ground.

The bench pay streak south of the Olson bench claim has not been abandoned and is being thoroughly prospected by drilling in order to outline the southern end of the pay streak. Because of the thickness of the overburden, new methods will be required for mining this deeper ground.

The feasibility of reworking the bench tailings was tested in 1966 by the construction of an experimental plant, called the "mudhog," which was installed on the bench pay streak opposite claim $4 B$, Salmon River. This unique operation was necessary because many of the grains of platinum enclosed in indurated clay of glacial origin that had not disintegrated under weathering and did not disintegrate in the trommel screen of the dredge were not recovered. Hence in the "mudhog" it was necessary to crush both the clay and associated gravels, as the two were not separable. This was an expensive operation, yet the plant, operated for only one summer, returned a profit.

Unworked ground remains in the valley floor from claim $6 \mathrm{~A}$ to claim 11A; this area will probably be mined by a dragline excavator. A similar operation started in 1968 is the mining of the pay streak of Platinum Creek from the mouth of Squirrel Creek upstream to and possibly beyond the mouth of Dry Gulch.

The principal source of the platinum metals in this district is the mass of ultrabasic rocks that forms the ridge known as Red Mountain. All headwater tributaries of the Salmon River that drain the east side of this ridge were found to be platinum bearing. Consequently, the western side of Red Mountain also was of interest, and in 1936 and 1937 considerable exploratory drilling was done in a triangular area bounded by the Smalls River, Red Mountain, and Kuskokwim Bay, particularly in the valleys of Seattle and Last Chance Creeks. A dozen or more holes were drilled by various operators to depths ranging from 30 to 110 feet; bedrock was reached in only a few of these, and no platinum was found. Platinum was reported from one of these drill holes, but it was later established that this report was false. Small amounts of platinum have been found along the beach of Kuskokwim Bay, but no workable deposits have been located.

A little platinum was found and recovered in later years from a small cirquelike opening in the west flank of the Red Mountain ridge about 1 mile north of the low saddle between the head of Platinum Creek and Kuskokwim Bay. A drill hole sunk in the valley of the
Smalls River along the north side of the gravel road, about 2.6 miles S. $52^{\circ}$ E. of Platinum, reached bedrock at a depth of 192 feet and yielded both platinum and gold; this discovery did not lead to the location of any workable ground.

The early small-scale mining operations from 1927 through 1934 are estimated to have yielded about 3,000 troy ounces of platinum metals. From 1934, when large-scale mining began, to the end of 1972, the production is believed to have been well over half a million ounces, with a maximum yield in 1938 of about 32,000 ounces.

\section{AGKNOWLEDGMENTS}

The four principal owners of the Goodnews Bay Mining Co. gave every possible service in the preparation of this report. They made available all their data on mining and prospecting and furnished a complete record of all screen and chemical analyses on cleanups, together with the localities corresponding to these cleanups. Ed Olson, a vice-president of the company, cooperated in many ways, acting not merely as host but as a guide and field helper. Charles J. Johnston, treasurer of the company, has for 38 years kept the writer informed on current mining operations and has provided detailed annual reports of the company's production, allocated to the six platinum metals and gold. Finally I am most grateful to the owners for their hospitality at the time of my last visits to the property in 1966, 1968, and 1969.

Other officers and employees of the company have been equally cooperative. Gene D. Connor, secretary of the company, and Mrs. Connor, who has charge of the separatory work in the laboratory, have been very helpful. The writer is greatly indebted to the company's mining engineer, Joseph F. Fisher, for his useful suggestions, his cooperation in the acquisition of samples, and many other contributions.

For technical advice and certain analyses mentioned in the text, I am greatly indebted to John Cochrane of the Cochrane Laboratories, formerly of Tuckahoe, New York. I am also indebted to George E. Desborough and Edward Dwornik, of the U.S. Geological Survey. Specific contributions of these men are credited in later sections of this report.

\section{GEOGRAPHY}

The region lying between the southwestern parts of the Nushagak and Kuskokwim River valleys (fig. 1) may be divided into three physiographic provinces. In the central part of this region are high rugged mountains like the Tikchik and Ahklun Mountains, some of which have altitudes of 5,000 feet or more. This alpine province, intensely glaciated during the Pleis- 


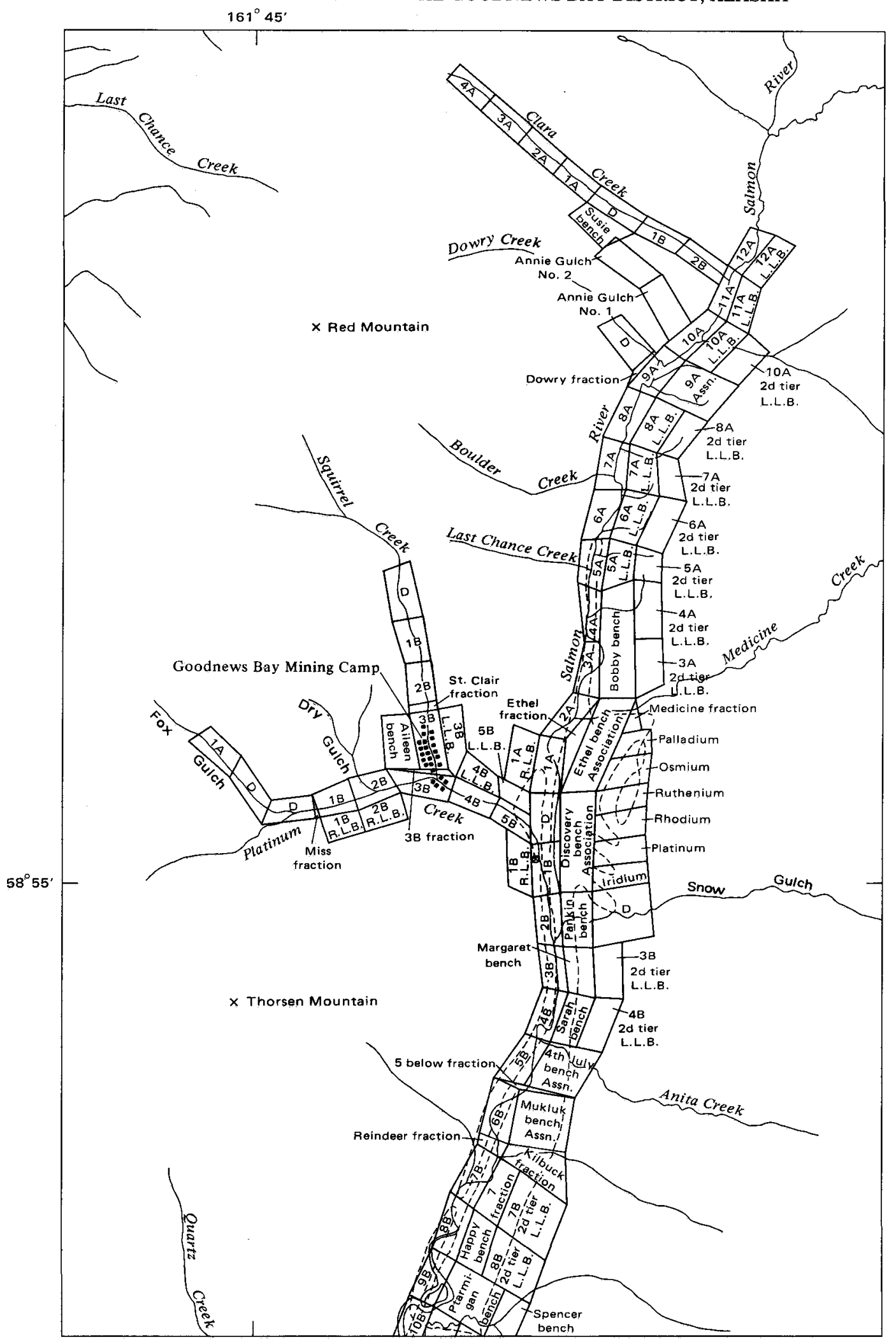

FIGURE 3.-Sketch map of placer mining claims in the valley of Salmon River and its tributaries showing path of dredge along pay streaks. 


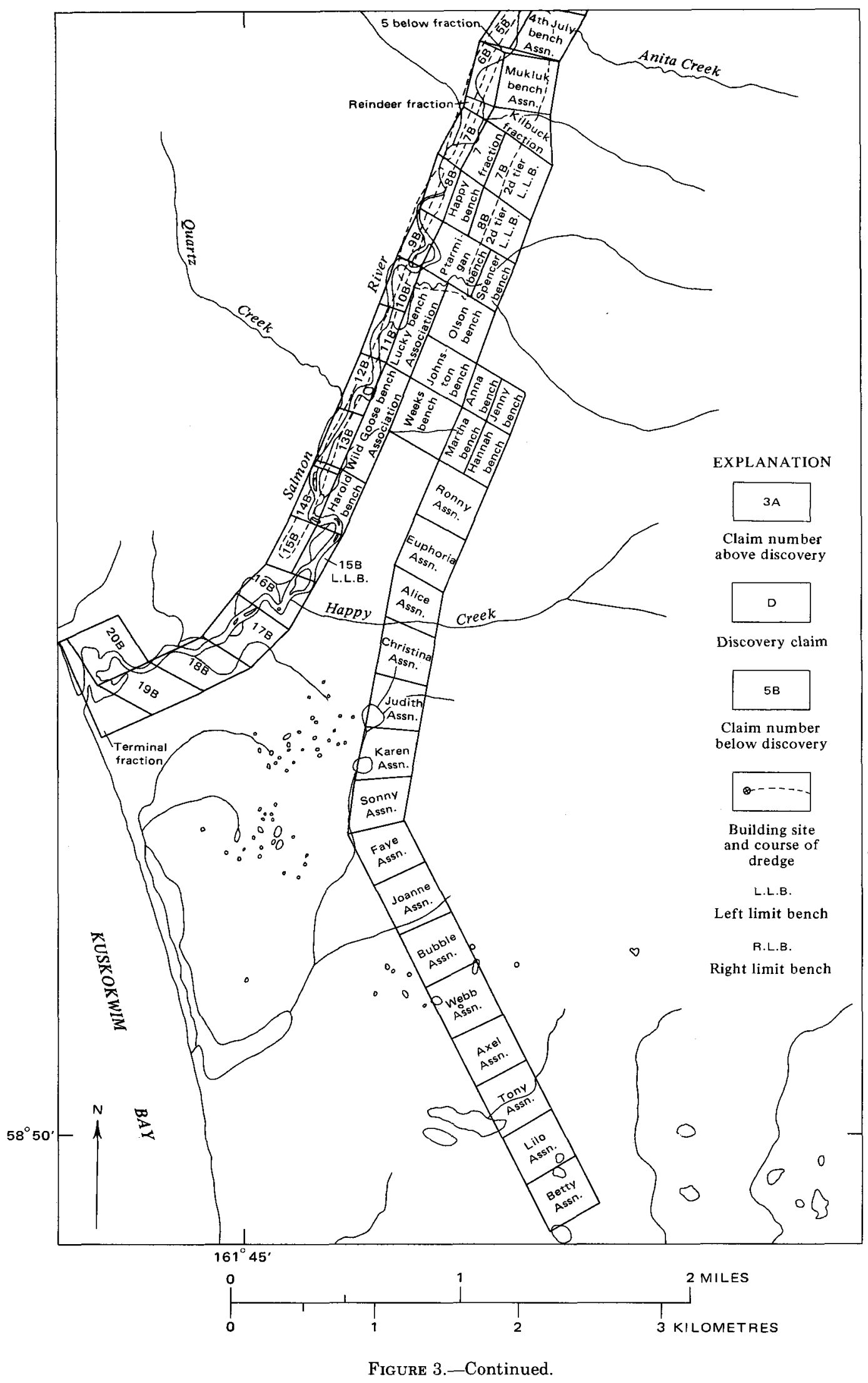


tocene Epoch, was the source of numerous glaciers that discharged through the master valleys, mainly to the west and south; some of these glaciers reached the coast and moved farther west into the Bering Sea. The glaciated mountains and deep glacial lakes of the Tikchik Mountains have been described by Mertie (1938). Between this alpine province and the coast is a piedmont province consisting of low and smoother hills that attain altitudes of 1,000 to 3,000 feet, decreasing in height toward the sea. Valley glaciers have occupied these hills, and at an early stage in the Pleistocene Epoch, a large part of this province is believed to have been covered with ice. Thus the piedmont province shows features of both glacial and nonglacial origin. At many places, a low foreland, nearly devoid of relief, lies between the low hills and Kuskokwim Bay, the third or coastal province of the region.

The Goodnews Bay district lies mostly within the piedmont province; a triangular foreland southeast of Platinum and a similar area from the mouth of the Salmon River into the valley of the Kinegnak River lie within the coastal foreland. Red Mountain, altitude 1,887 feet, is the northern part of a ridge that lies between the Salmon River and Kuskokwim Bay, extending from Platinum Creek northward to the valley of the Smalls River. Susie Mountain (fig. 4), altitude 1,805 feet, together with its environs, constitutes the northern part of another ridge roughly parallel to Red Mountain that forms the eastern limit of the valley of the Salmon River.

Red Mountain, the highest part of the ridge and closest to the sea, is the most prominent landmark in this area. The eastern slopes of the mountain are moderately steep, the maximum slope on the spurs being about 25-30 percent. The western slopes are much steeper; where the mountain rises directly from the sea, the slopes are precipitous, rising about 1,500 feet in half a mile (fig. 5). Several cirquelike basins are present at and near the heads of Last Chance and Seattle Creeks. Cirquelike basins border the eastern side of Susie Mountain, in the headwaters of Fog Creek; the uppermost part of the valley of Susie Creek, which drains southeastward from Susie Mountain, is a similar, though less well developed, basin.

Two mountains of lower altitude are conspicuous features along the valley of the Salmon River. Thorsen Mountain (fig. 6), altitude 1,110 feet, is about 3 miles south of Red Mountain. Kemuk Mountain, about 3 miles S. $16^{\circ} \mathrm{W}$. of Susie Mountain and a little higher but less prominent than Thorsen Mountain, is merely a flat dome on the ridge that forms the eastern boundary of the Salmon River.

The Goodnews River (fig. 1), flowing westward to Goodnews Bay, is the master stream of this region, and one of its tributaries, the Smalls River (fig. 2), bounds the Goodnews mining district on the north. The Salmon River (fig. 2) heads against the central valley of the Smalls River and flows S. $20^{\circ} \mathrm{W}$. for about 7 miles, then S. $60^{\circ} \mathrm{W}$. for about 1 mile, discharging into Kuskokwim Bay. The Salmon River has several tributaries from both sides of its valley; the most important of these are the western headwater tributaries that drain the eastern slopes of Red Mountain. These tributaries, from south to north, are Platinum Creek with its tributaries Fox Gulch, Dry Gulch, and Squirrel Creek, succeeded northward by Last Chance, Boulder, Dowry, and Clara Creeks. Still farther north is McCann Creek, which discharges into the Smalls River. All these streams are platinum bearing, and five of them were found to have workable placers. Medicine Creek is the only large eastern tributary of the Salmon River.

Goodnews and Chagvan Bays (fig. 2) are shallow tidal estuaries that indent the coast of the Bering Sea and represent drowned or flooded valleys. Two sand spits,

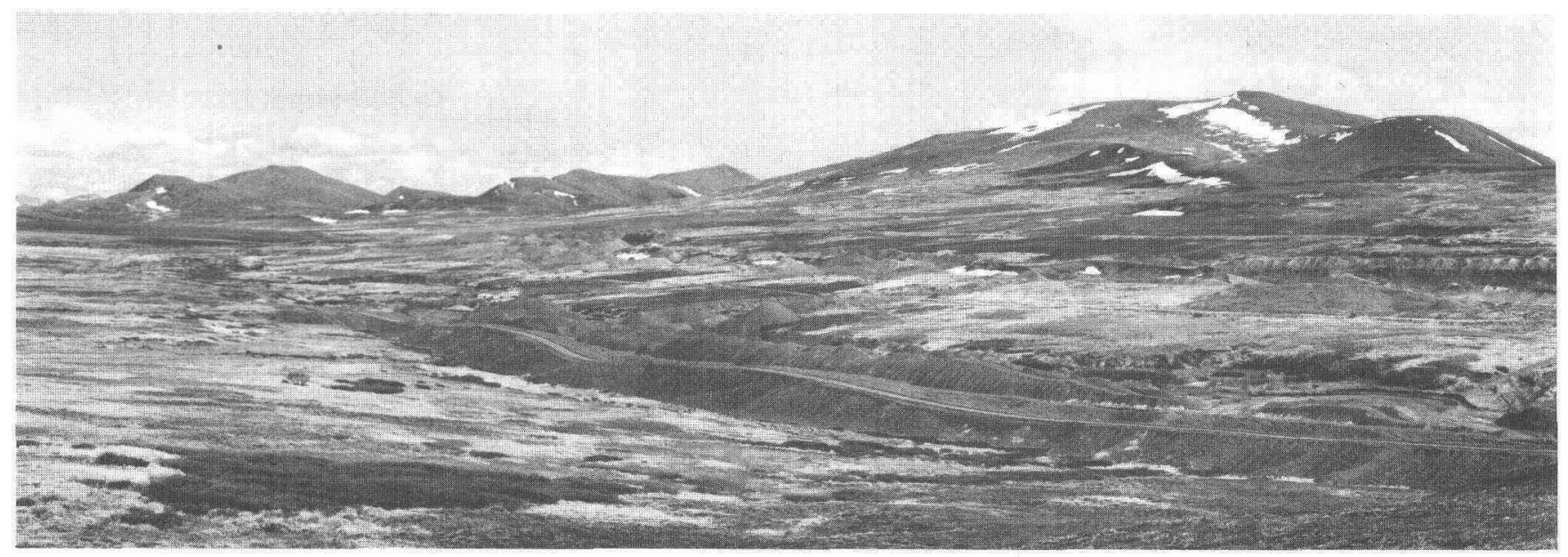

Figure 4.-Panoramic view of west side of Susie Mountain and upper valley of Salmon River. View northeast. 


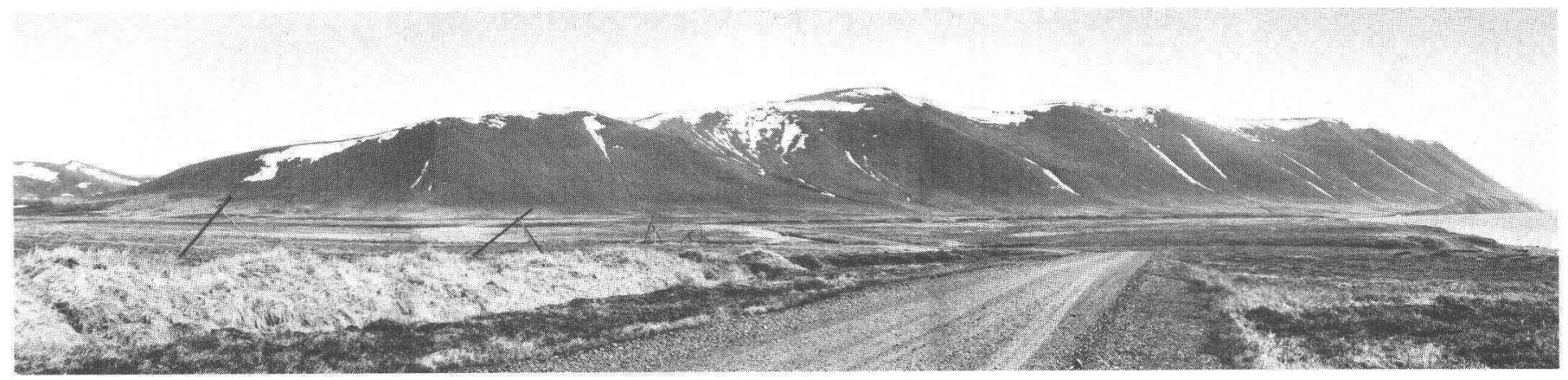

FIGURE 5.-Panoramic view of west side of Red Mountain ridge. View south-southeast.

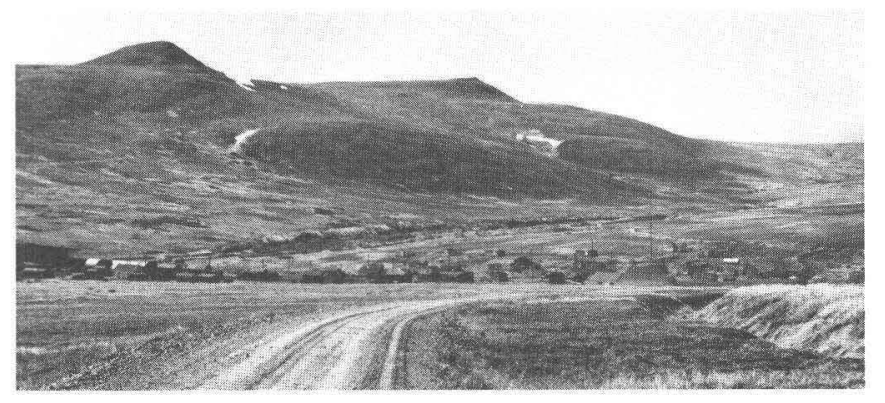

FIGURE 6.-Thorsen Mountain, viewed from northeast, showing upper valley of Platinum Creek and camp of Goodnews Bay Mining Co.

called the North Spit and South Spit, mark the entrance to Goodnews Bay. The settlement of Platinum, at the southeast end of the South Spit, is connected with the camp of the Goodnews Bay Mining Co. by a 9-mile-long gravel road. Another gravel road leads 3 miles northward from Platinum to the tip of the South Spit, where the company's oil tanks and dock are located.

Goodnews Bay has a maximum width of 7 miles, an entrance 3,700 feet wide, and a devious channel 8-12 feet deep to the head of the bay. A drill hole, at a site about 2,000 feet south of the north shore, was driven through clayey sediments reaching bedrock at a depth of about 180 feet below water level. Similar conditions prevail at Chagvan Bay, where drilling on a sand spit west of the bay showed bedrock at a depth of 244 feet. These figures indicate that sea level at some time during the Pleistocene Epoch was 180-235 feet below the present sea level. The maximum depth to bedrock, and therefore the maximum lowering of the sea level, has not been determined.

The valley of the Salmon River is nearly straight, and its width between the bounding ridges is $3-4$ miles. The floor of the valley ranges in width from 500 to 2,000 feet; it is narrowest about 2,000 feet upstream from the mouth of Medicine Creek and widest, except at its mouth, in the short stretch between Medicine Creek and Snow Gulch. The average gradient of the valley floor, from the mouth of Clara Creek to the mouth of Happy Creek, is about 32 feet per mile, or about 0.6 percent. The western headwater tributaries of the Salmon River are of principal economic interest. The largest of these tributaries is Platinum Creek with its tributary Squirrel Creek. The camp of the Goodnews Bay Mining Co. is located in the valley of Squirrel Creek (fig. 7). The largest eastern tributary of the Salmon River is Medicine Creek.

The valley of the Salmon River is asymmetrical in cross section with a gentle slope on the east side, whereas on the west side the river tends to cut against

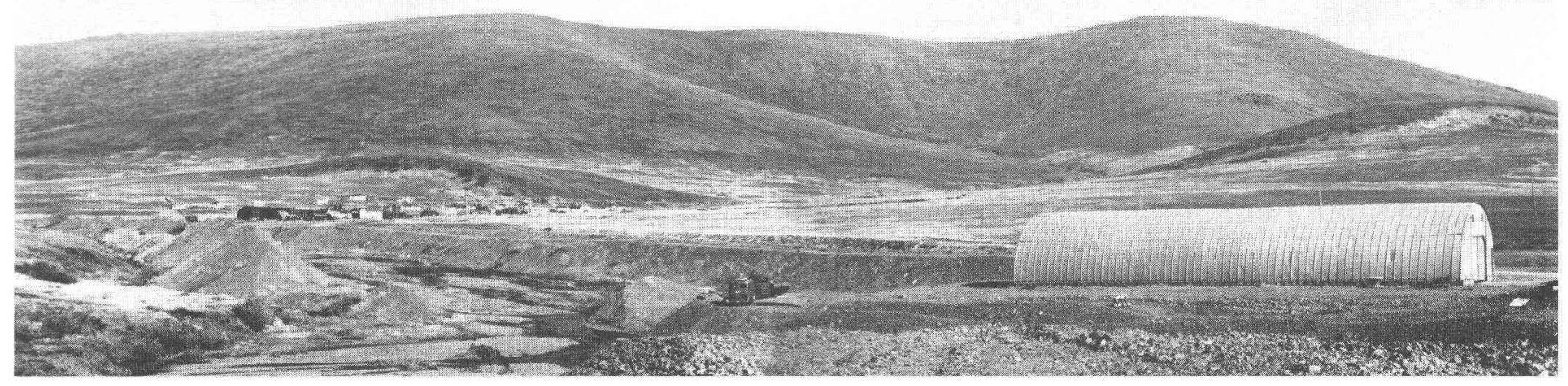

Figure 7.-Panoramic view showing camp of Goodnews Bay Mining Co. and the upper valley of Squirrel Creek. 
between these two hardrock units is therefore rather indefinite.

The lavas are predominantly basalts with a smaller proportion of andesites, and the tuffaceous rocks are petrographically similar. Owing to replacement by secondary minerals such as chlorite and epidote and to albitization of the feldspars, the exact petrographic character of the lavas is obscure, although some of the basalts are clearly porphyritic. The accessory minerals of the lavas are chiefly iron ores altered to iron hydroxides but include apatite and sphene. The tuffs are greenish fragmental rocks believed to represent volcanic ejectamenta, partly waterlaid and partly of subaerial origin. The age of the lavas and tuffs is indeterminate, but they appear to lie conformably above the argillaceous and siliceous rocks and are therefore considered to be probably late Paleozoic in age.

\section{INTRUSIVE ROCKS}

Two principal masses of ultrabasic rocks are present in this district. The larger of the masses forms the elongate ridge known as Red Mountain, which lies west of the headwaters of the Salmon River. This mass trends about N. $20^{\circ} \mathrm{E}$. and has a length of about 6 miles, a maximum width of 1.9 miles, and an area of about 7.3 square miles. It is the source of practically all the platinum metals that have been found on the Salmon River and its tributaries. The smaller intrusive body crops out in a belt that lies west of Susie Mountain and trends $\mathrm{N}$. $40^{\circ} \mathrm{E}$. This mass is predominantly perknite and is not a major source of the platinum metals in the valley of the Salmon River.

Granitic intrusive rocks along the southeastern side of the upper valley of the Smalls River occupy a belt that trends N. $57^{\circ}$ E. with a known lengths of about 4-5 miles. These rocks consist of adamellite (quartz monzonite), granodiorite, and tonalite (quartz diorite); they are unrelated to the platinum placers but may be one of the sources of the placer gold in the deposits.

\section{ULTRABASIC ROCKS}

The intrusive body at Red Mountain is essentially a dunite with peripheral borders of perknite; it is altered surficially to yellowish brown. The unaltered dunite is a black to greenish-black rock that consists almost entirely of olivine with minor amounts of monoclinic pyroxene and iron ores. Some of the olivine is replaced by serpentine, at some places to the extent that it may be called serpentinite. Disseminated iron ores consisting of magnetite, ilmenite, and chromite are scant in the dunite, but concentrations of such ores are locally present, as between the heads of Squirrel Creek and Fox Gulch, where residual cobbles are found.

Two complete chemical analyses of the dunite of Red Mountain were made by E. T. Erickson, of the U.S. Geological Survey: one (A) of a composite sample of fresh unaltered dunite, with a representative content of marginal perknitic rocks, and one (B) of the oxidized shell that forms a veneer on these ultrabasic rocks (table 1).

TABLE 1.-Chemical analyses, in weight percent, of ultrabasic rocks, Red Mountain ridge [Analyst, E. T. Erickson; N. D. = not detected]

\begin{tabular}{|c|c|c|c|}
\hline & & A & B \\
\hline $\begin{array}{l}\mathrm{SiO}_{2} \\
\mathrm{Al}_{2} \mathrm{O}_{3} \\
\mathrm{Fe}_{3} \mathrm{O}_{3} \\
\mathrm{FeO} \\
\mathrm{MgO} \\
\mathrm{CaO} \\
\mathrm{Na}_{2} \mathrm{O} \\
\mathrm{K}_{2} \mathrm{O} \\
\mathrm{H}_{2} \mathrm{O} \\
\mathrm{H}_{2} \mathrm{O} \\
\mathrm{TiO}_{2} \\
\mathrm{Cr}_{3} \\
\mathrm{MnO}_{3} \\
\mathrm{NiO} \\
\mathrm{CuO}\end{array}$ & 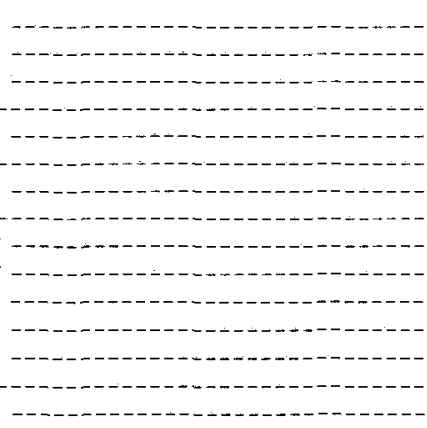 & $\begin{array}{r}39.20 \\
1.50 \\
3.10 \\
7.35 \\
37.79 \\
5.66 \\
\text { N.D. } \\
\text { N.D. } \\
5.81 \\
.19 \\
.05 \\
.27 \\
.01 \\
.077 \\
.007\end{array}$ & $\begin{array}{r}38.54 \\
.78 \\
5.29 \\
5.99 \\
42.29 \\
.34 \\
\text { N.D } \\
\text { N.D. } \\
5.53 \\
.43 \\
.14 \\
.13 \\
.01 \\
.053 \\
.004\end{array}$ \\
\hline $\mathrm{CuO}$ & Total & 100.014 & 99.527 \\
\hline
\end{tabular}

A. Unaltered dunite and perknite (composite sample).
B. Oxidized shell on ultrabasic rocks of Red Mountain.

Sample A was taken primarily to ascertain the composition of the ultrabasic rocks. Although the rock was tested for the platinum metals, it was realized that the platinum-metal content would probably be too low for detection by ordinary analytical methods. For such a determination it would be necessary to take a large sample of 50-100 pounds, to crush and mill this sample, and then concentrate the accessory minerals contained. Such a sample, however, might yield an abnormally low content, as all the available data indicate that the platinum metals are not evenly disseminated throughout the dunite but tend to be concentrated at certain loci.

The presence of chromite $\left(\mathrm{Cr}_{2} \mathrm{O}_{3}\right)$ shown by the chemical analyses is significant, as the placers contain platinum nuggets that are intergrown with or have adhering chromite. Moreover, chromite constitutes a small but significant part of the accessory minerals recovered with the platinum metals. In an analysis of pebbles of chromite recovered from the placer concentrates made by E. T. Erickson, the tenor in platinum metals was found to be 0.05 troy ounce per ton of chromite. Ilmenite and chromite are not readily 
separated magnetically, as the magnetic susceptibility of ilmenite is only slightly greater than that of chromite. The magnetite is known to contain small amounts of the platinum metals, and for these reasons all the iron ores are crushed, milled, and concentrated in order to recover the contained platinum metals.

\section{UNCONSOLIDATED DEPOSITS}

Unconsolidated or alluvial deposits of Quaternary age are spread over a large part of the district; these include morainal, glaciofluvial, fluvial, eluvial, residual, marine, and eolian deposits. The most extensive are those of fluvial and glaciofluvial origin and the reworked morainal debris. These deposits are not mappable genetically but are divided approximately into older and younger deposits, essentially of Pleistocene and Holocene age.

The older alluvial deposits consisting largely of glaciofluvial or outwash deposits lie in the valley bottoms of the larger streams, such as the Smalls, Kinegnak, and Unaluk Rivers, where they are covered by younger fluvial deposits, but they extend upward onto the lower spurs and ridges to altitudes of 250-500 feet. Moraines constitute a part of the older deposits; included with these are most of the residual and eluvial deposits. In the aggregate, the older deposits occupy about a fourth of this district.

Older alluvial deposits occupy a large part of the valley of the Salmon River, but the original glacial debris has been generally reworked to form both older and younger fluvial deposits. An ancient glacier that overrode this district left a moraine in the valley of the Salmon River; after the retreat of the ice, this morainal material was reworked by an ancient stream whose channel now occupies an alluvial-filled depression along the east wall of the Salmon River. This channel was discovered by drilling and was opened by mining; its older fluvial deposits were found to be mainly clay with smaller amounts of sand and gravel. These reworked morainal deposits are platiniferous and constitute what is now designated as the bench pay streak. Glaciofluvial deposits of later origin are present at the upper and lower ends of the Salmon valley.

Younger alluvial deposits form the valley floors of all the principal rivers and their tributaries; with these belong the eolian and marine deposits. The younger deposits of the Salmon valley are mainly of fluvial origin and consist largely of materials of local origin; they include reworked glaciofluvial debris at the head of the valley and similar materials at its southern end. The alluvial deposits in the valley of Platinum Creek and its tributaries consist of gravels and related alluvium derived from the ultrabasic rocks of Red Mountain and from adjacent sedimentary and igneous rocks. The differences in the origin of these deposits are reflected in the accessory minerals recovered from the alluvial sands and gravels.

\section{GEOMORPHOLOGY}

Geomorphology deals with the history of surficial geologic changes as revealed by the interpretation of physiographic landforms and is therefore essential for an understanding of the history and formation of placers. Within the Goodnews Bay district glaciation has been one of the most effective erosional and depositional agencies. Eustatic rise and fall of sea level during the Pleistocene Epoch also were controlling factors. But it is not generally possible to closely correlate the erosional events in the Salmon Valley with changing base levels of erosion caused by eustatic changes in sea level, because local base levels of erosion produced by glaciation and glacial deposits had commonly more effect than changing sea levels. Numerous statements regarding the geomorphic history will be made herein without presenting proof, but these statements are adequately substantiated by data that are revealed in the description of the two pay streaks in the valley of the Salmon River.

All glaciation in western Alaska was formerly referred by geologists, including the writer, to the Wisconsin Stage of the Pleistocene Epoch. Multiple Pleistocene glaciations were first recognized by the writer on Seward Peninsula during the summer of 1940 and within a month were confirmed at Nome (McNeil and others, 1943 , p. 69-76). This reopened the entire Pleistocene history and led to the recognition of four glaciations, generally correlative with those present elsewhere in North America.

Four major glaciations and three major interglaciations have been recognized throughout the world as distinctive of the Pleistocene Epoch. Glaciations accepted in the United States south of Canada are Nebraskan, Kansan, Illinoian, and Wisconsinan; the interglaciations, designated in the same order, are Aftonian, Yarmouth, and Sangamon. The short span of time succeeding the Wisconsin glaciation is now called the Holocene Epoch, although this may represent merely the beginning of a fourth interglaciation. These designations are applied sequentially in the Goodnews Bay district merely to indicate the order of the glaciations and interglaciations, with no intention of correlating closely with the same intervals elsewhere in North America.

The duration of the Pleistocene and Holocene Epochs has been variously estimated, but the tendency in recent years has been to lengthen the span of time accepted in earlier appraisals. In a chronology based upon the frequency of Globorotalia menardii in deep-sea 
sediments, proposed by Ericson and Wollin (1968), the spans of the four glaciations, from oldest to youngest, are charted graphically as approximately 275,000 , $475,000,175,000$, and 180,000 years. The durations of the interglaciations, including the post-Wisconsin or Holocene Epoch, are 325,000,360,000, 160,000, and 50,000 years, a total of $2 \mathrm{~m} . \mathrm{y}$.

The history of the Pliocene Epoch is too obscure to warrant any definite statements regarding its climate, erosional history, and physiographic development. The general altitude of the hills was doubtless much greater than that of the present hills, as the available evidence suggests a general rate of erosion of about 0.0001 foot per year (Dole and Stabler, 1909). This, together with the latitude of this region, suggests the existence of some alpine glaciation in the high mountains, but no glaciers are believed to have reached the sea. There is some evidence, however, that a Pliocene river may have occupied the valley of the Salmon River; it is definitely known that such a stream existed and persisted as the principal drainage channel during the Nebraskan glaciation and throughout the Aftonian Interglaciation in a channel that now occupies a depression in the east wall of the valley of the Salmon River.

The earliest regional glacier, believed to have been of Nebraskan age, advanced from the east and not only filled the preexisting valley but overrode all but the summits of the bounding walls of this valley. Moving athwart the course of a narrow valley, this glacier probably did not erode to bedrock, and therefore any preexisting placer platinum metals that were close to bedrock or within the crevices of bedrock were undisturbed. Similar conditions are known in certain placer deposits south of the Alaskan Range. In melting, this glacier left a large valley moraine, which was later reworked into a clayey fluvial deposit that has persisted, with incipient induration, to the present time and now constitutes the principal alluvium in the bench channel of the valley of the Salmon River.

This ancient valley has had a complex history. After the retreat of the Nebraskan ice, the valley was drained by two streams, one flowing northward, the other discharging southward to the Kinegnak River; the lower course of Platinum Creek drained northeastward to the north-flowing stream, thus producing a backhand or "chulitna" drainage. This inference is based upon high iridium values in the placers of the bench channel north of Medicine Creek. Later, probably during the Aftonian, the drainage of the north-flowing stream was captured by the south-flowing stream, and the alluvial divide between these two streams was obliterated. The altitude of the bedrock floor of this ancient valley was unrelated to the regional rate of erosion but instead was controlled by various local base levels of erosion that existed throughout the early Pleistocene, as determined both by glaciation and by changing sea levels. Eventually this ancient stream developed a very broad valley, with a bedrock gradient higher than that of the present valley floor.

Kansan Glaciation is believed to have existed in this region, but its history is obscure because the succeeding Illinoian Glaciation destroyed most of its glacial deposits. This situation is analogous to the obliteration of the evidence for pre-Wisconsin glaciation by Wisconsin ice south of the Alaska Range. One suggestion of the presence of Kansan Glaciation and the existence of Kansan outwash deposits at the south end of the valley of the Salmon River relates to the distribution of gold in the placers of the present valley, as later described. Kansan ice is believed to have reached the ancient oceanic shoreline, both in the valleys of the Smalls River and of the Kinegnak River. The total effect of Kansan Glaciation is not really known, but one result was the creation of a new stream channel in the valley of the Salmon River. Either by damming or by excessive alluviation in the old channel, or both, the river in the old Aftonian channel was gradually shifted westward and was superposed upon its western bedrock wall so that a new stream channel began to be carved. The resulting stream was ancestral to the present Salmon River. A new pay streak, thus begun during the Yarmouth Interglaciation, has been continuously in process of development since that time.

Illinoian Glaciation was clearly present in this district, and glaciers that reached the sea occupied the valleys of the Smalls and Kinegnak Rivers. The valley of the Salmon River was not glaciated, yet important effects were produced at both ends of the valley. At its upper end, the Smalls River lobe of the Goodnews glacier deposited erratic boulders at the north end of the Red Mountain ridge up to an altitude of 825 feet, but the ice was shunted seaward, scouring the west side of Red Mountain and removing any platinum deposits that may have been present. In the retreat of the Goodnews glacier, thick deposits of glaciofluvial materials were deposited at the head of the valley of the Salmon River, and a considerable part of these deposits have been reworked to produce many of the fluvial deposits of the present Salmon River. At the lower end of the valley of the Salmon River, the Unaluk glacier overrode a hill with an altitude of 677 feet south of Kemuk Mountain and another hill with an altitude of 575 feet about 2 miles south of Thorsen Mountain. The most important effect of the Unaluk glacier was that it scoured out and thereby destroyed the southern end of the valley pay streak on claim 15B (fig. 4), north of the mouth of Happy Creek. That it did not destroy the old bench pay streak is doubtless due to the much greater depth of that channel. 
The Sangamon Interglaciation appears to have been a time of alluviation in the valley of the Salmon River, owing to a rising base level of erosion. The materials for the fluvial deposits came largely from the hills on both sides of the valley but also from the Illinoian glaciofluvial deposits at the head of the valley. These deposits contained little or no clay except on claim 4B (fig. 4) where, for a short distance, the bench and stream deposits are laterally contiguous and clay was contributed by erosion of the bench deposits.

The Wisconsin Glaciation has not been satisfactorily resolved within this district. Porter (1967), from his studies of the glacial deposits at the head of the Salmon River and in the lower valleys of the Kinegnak and Unaluk Rivers, believes that the Wisconsin was characterized by an early and a late advance of glacial ice separated by a relatively short time interval; to these substages he assigned the local names Unaluk and Chagvan. It is unlikely that either of these glacial lobes reached the ancient shoreline. Erosion and sedimentation were more directly controlled by oceanic base levels of erosion during the Sangamon, Wisconsin, and post-Wisconsin than during the earlier glaciations and interglaciations; the overall effect has been the broadening and alluvial filling of the valley of the Salmon River.

\section{ECONOMIC GEOLOGY PLATINUM METALS COMPOSITION}

The precious metals of the Goodnews placers include the six platinum metals and gold. Platinum is the principal metal recovered; the other platinum metals are iridium, osmium, ruthenium, rhodium, and palladium. The average content of gold is only 2.4 percent of the output. Detailed data giving the percentages of each of the precious metals, as annually produced from 1936 to 1972 , are given in another part of this report.

The platinum metals occur mainly as two alloys, known on the basis of abundance as the principal (or major) alloy and the minor alloy. The principal alloy is designated by the generic name platinum, although it contains the five other platinum metals; the minor alloy is called osmiridium. These two alloys were initially recognized in polished sections of grains and nuggets (Mertie, 1940a), intergrown in a pseudoeutectic fabric. They subsequently have been found to contain minute inclusions of certain platinum minerals and a number of rock-forming minerals; one platinum mineral has been found that is not a part of either alloy. Both alloys have variable compositions such that specific mineralogical names are not warranted. The ratio of these alloys is variable within the placers and is inconstant in different lodes. They are so intimately intergrown that it is almost impossible to obtain samples of each alloy suitable for chemical analysis. Electron-probe analyses and related disciplines, though less accurate, appear to be the most feasible methods for approximate determinations of composition.

The platinum alloys react differently with inorganic acids and other reagents than do the purified metals. These reactions are not quantitatively predictable because they depend upon the compositions of the alloys wherein these metals occur. Pure platinum is not attacked by the common inorganic acids but is dissolved in aqua regia, though less readily than gold. Pure iridium and rhodium are only partly soluble in aqua regia, and osmium and ruthenium are quite insoluble. Palladium is soluble in aqua regia but is also dissolved by hot nitric or sulfuric acid. The platinum alloys, however, behave differently.

The physical and chemical properties of the platinum metals were fully described in an earlier publication (Mertie, 1969), and a new compilation of some of these properties was made by Johnson, Matthey \& Co., Ltd. (1972). The magnetic susceptibility of the platinum metals, especially of the alloys, is an important practical criterion, as it bears directly upon the separation of these alloys from one another and from the accessory black sand recovered in placer mining. In general, osmiridium has a much smaller magnetic susceptibility than the principal alloy. Theoretically this should provide a method for separating very fine grains of the two alloys for chemical analyses. Actually, this method is impracticable because both alloys contain minute inclusions of magnetite, although such inclusions are more plentiful in the principal alloy. An attempted electromagnetic separation by this method, however, yielded a hitherto unrecognized platinum mineral, later identified as cooperite. This is an iron-gray to black cubic mineral with a metallic luster, a density of about 10.0 , and a very low magnetic susceptibility. It is insoluble in aqua regia and on ignition decomposes to a sponge. A chemical analysis of its cation is shown in table 2 .

\section{TABLE 2.-Chemical analysis, in percent, of cation of cooperite}

[Analyst, John Cochrane, Cochrane Laboratories]

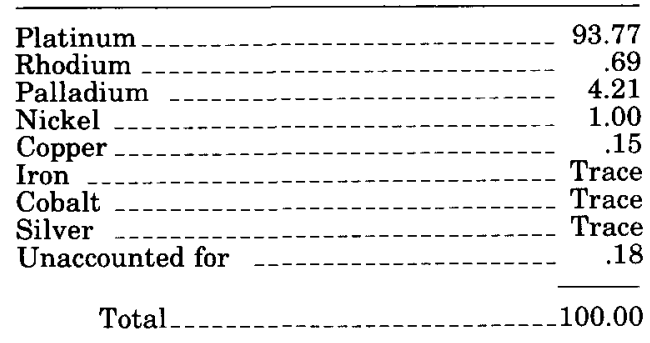


The anion was not determined quantitatively but was found to consist mainly of sulfur, with a significant amount of arsenic and a trace of antimony. The formula may therefore be written as ( $\mathrm{Pt}, \mathrm{Pd}, \mathrm{Ni}$ ) ( $\mathrm{S}, \mathrm{As})$. This differs from Cooper's formula of 1926 in that palladium precedes nickel and arsenic is added to sulfur.

The five least electromagnetic subfractions of the sample, as obtained by a Frantz separator, contained variable amounts of cooperite and both alloys; from these, numerous grains of osmiridium were handpicked under the microscope by John Cochrane for study and analysis. Two distinct types of osmiridium were recognized:

Type A. Well-formed hexagonal plates ranging generally in diameter from 3.5 to 14.3 microns with a maximum diameter of 28 microns. These plates have a relatively constant platinum content of about 2.5 percent and an Ir:Os ratio of about 0.5. An examination under high magnification showed that these hexagonal plates occur in parallel sheets separated by a lesser number of nonparallel platelets. The preferred orientation of the larger plates appeared to coincide with the major orientation of some of the included crystals of magnetite.

Type B. Small to large irregular-shaped grains erratically distributed in the principal alloy, generally typified by a platinum content of 10 percent and an Ir:Os ratio greater than 5.0. This type constitutes on the average about 80 percent of the osmiridium present in the five subfractions and probably in general for the Goodnews product.

The osmiridium problem was studied in another way by Edward Dwornik, of the U.S. Geological Survey. A nugget owned by the writer had been cut and polished so that it clearly showed the irregular grains of osmiridium, with a silvery luster and high relief, embedded in the principal alloy. The osmiridium contained minute inclusions of magnetite, but the principal alloy contained more inclusions of magnetite and some of chromite. Utilizing electron probe spectroscopy, Dwornik and his assistants made an approximate analysis, as show in table 3 . The content of platinum in

TABLE 3.-Electron microprobe analysis, in percent, of osmiridium

[Analyst, Edward Dwornik]

\begin{tabular}{|c|c|}
\hline 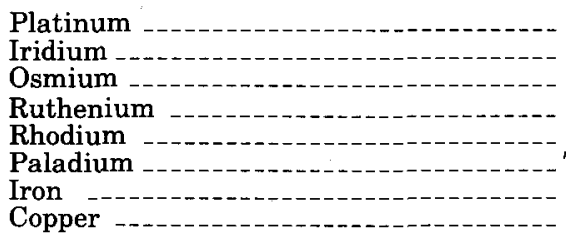 & $\begin{array}{c}15 \\
48 \\
26 \\
1 \\
4 \\
\text { Trace } \\
\quad 2 \\
1\end{array}$ \\
\hline Total -- & 97 \\
\hline
\end{tabular}

this analysis correlates fairly well with the type B osmiridium as determined by Cochrane, but the Ir:Os ratio is 1.85 , which is closer to the type A osmiridium. Possibly the osmiridium of the nugget was a mixture of types $A$ and $B$.

Laurite was identified by Leonard, Desborough, and Page (1969) in osmiridium contained in a nugget from the Goodnews Bay district. This mineral, with a formula given as $\mathrm{RuS}_{2}$, is very hard and occurs in roundish equant subhedral to irregular grains embedded in osmiridium. Three other minerals of the platinum-group metals have been identified by G. A. Desborough (written commun., 1970) in the principal alloy. One of these is a new iridium-palladium sulfide with a composition that is approximately 68 percent iridium, 14 percent palladium, and 18 percent sulfur. The second mineral consists of a few grains of sperrylite. The third is a new mineral to which the name of mertieite has been assigned (Desborough and others, 1973). It has a composition of $\operatorname{Pd}_{5}(\mathrm{Sb}, \mathrm{As})_{2}$ and contains about 0.5 percent copper. The grains range in size from 0.10 to $0.50 \mathrm{~mm}$; most are smaller than $0.25 \mathrm{~mm}$. Mertieite is a brassy yellow mineral with a density of about 11.6 and a hardness comparable to that of magnetite. It is distinctly anisotropic with a symmetry that suggests a classification in the monoclinic system.

\section{ANALYSES}

Bulk samples of the platinum metals are prepared for analysis and for subsequent refining by treating them with hot aqua regia. In this procedure, most of the platinum, parts of the iridium and rhodium, and all the palladium are dissolved; but the osmium and ruthenium, and parts of the platinum, iridium, and rhodium that are alloyed with them, are unaffected and are rendered soluble by treatment with an alkaline oxidizing reagent. The completed analysis invariably shows a percentage of so-called impurities, which represent the alloyed dross, the mineral inclusions, and a part of the black sand that was not completely removed from the product before analysis. These impurities include also the dross of the gold and any lead shot, solder, or similar materials not recognized and removed by the producer. Silver, alloyed with the gold, is not ordinarily determined and is therefore included with the impurities. As recent investigations have shown that the two alloys contain minute grains of magnetite, ilmenite, chromite, and a number of other minerals, the true dross, or alloyed base metals, is difficult to determine precisely.

Chemical analyses of the platinum metals are laborious and costly. Matthey-Bishop, Inc., (the American branch of Johnson, Matthey \& Co., Ltd.), Baker \& Co., (now a branch of Englehard Industries, Inc.), D. C. 
Griffith \& Co., and a few other concerns of this caliber are competent analysts of the platinum metals. Many high-grade analyses have been made by the U.S. Bureau of Standards, in particular by Raleigh Gilchrist and his, coworkers. But analysts capable of making high-grade platinum analyses do not always make them, either because they are not needed or because the cost may be prohibitive; even if such analyses are made, it may not be to the advantage of the producer or the buyer to publish them. Relatively few high-grade platinum analyses are presented in the foreign literature.

Chemical analyses of the platinum metals are of different orders of dependability and are here divided into two general classes, designated as superior and inferior analyses. Superior analyses are considered to be those wherein the percentages of all six of the platinum metals are shown, with or without the dross. Hundreds of such analyses have been made by Matthey-Bishop, Inc., of the platinum metals produced by the Goodnews Bay Mining Co., and some have been made by other analysts. Inferior analyses are of several types having varying degrees of dependability.

\section{IMPURITIES AND DROSS}

The platinum metals differ physically from gold in many respects. Gold has few if any inclusions of other minerals; the platinum metals have many such inclusions. Gold is diamagnetic and may therefore be readily separated magnetically or electromagnetically from the black sand recovered in placer mining. As most of the platinum metals are paramagnetic and some are ferromagnetic, the black sand must be separated by mechanical methods and a small part remains unseparated. The platinum metals, unlike gold, cannot be melted, either by the producer or the refiner, owing partly to their high melting points but particularly to the fact that osmium sublimates by heating, giving off the poisonous gas $\mathrm{OsO}_{4}$, thus causing a metallic loss; to a lesser degree, ruthenium also sublimates. After all the platinum metals are in solution, the solute contains not merely the six platinum metals but also their dross and inclusions as well as a part of the unseparated black sand.

The true dross of the platinum metals is therefore generally indeterminate, and an overall component called impurities is tabulated with the analyses. Free of black sand, the alloyed dross can be determined approximately except for the contained mineral inclusions. For this purpose, Charles J. Johnston handpicked two samples of platinum metals free of black sand, and these were analyzed completely by Matthey-Bishop, Inc. The gold was not removed from these samples, as its content of dross would have been negligible. The two analyses are shown in two forms, $A$ and $B$, and are recomputed free of gold and silver as $A_{1}$ and $B_{1}$ (table 4).

The total mean content of iron and copper for these two samples is shown to be 8.77 percent; this includes not only the amounts of these two elements alloyed with the platinum metals but also any increments from included iron ores and the minute increment of dross from the gold. The stated percentage is therefore a maximum value and serves to prove that the principal alloy is not the alloy ferroplatinum, which contains 10-30 percent iron.

This analysis serves also for obtaining the fineness of the gold recovered with the platinum metals. Native gold, with alloyed silver, contains a very small percentage of alloyed base metals (mainly iron and copper), designated as dross $(D)$; the fineness of the gold $(F)$ is defined by the equation $F=\mathrm{Au} / \mathrm{Au}+\mathrm{Ag}+D$, where $F$ is stated in parts per thousand. Another useful ratio, particularly for gold recovered from lodes, is $\mathrm{Au} / \mathrm{Au}+\mathrm{Ag}$, but this fails to show the content of dross and is therefore not a proper definition of fineness. Accepting the conventional value for the dross of gold as 1 percent, which is close to its mean content in placer gold, a recomputation shows the fineness of this gold to be 932 . This value is unusually high for placer gold, as the mean value for Alaska has been shown by Mertie (1940b) to be about 870 . The increment is probably due to the reduction in size of the grains of gold produced by glacial transportation and the resulting solution of surficial silver.

The inclusions that occur in the platinum metals and are not properly a part of the true, or alloyed, dross have been studies by John Cochrane. In 1963, he separated 8

TABLE 4.-Complete chemical analyses, in percent, of two samples of platinum metals free of black sand [Analyses by Matthey-Bishop, Inc.]

\begin{tabular}{|c|c|c|c|c|}
\hline & A & $\mathbf{A}_{\mathbf{1}}$ & B & $\mathrm{B}_{1}$ \\
\hline Platinum _. & 74.02 & 75.79 & 73.89 & 75.72 \\
\hline Iridium & 10.15 & 10.39 & 10.10 & 10.35 \\
\hline Osmium & 1.87 & 1.92 & 1.95 & 2.00 \\
\hline Ruthenium & .15 & .15 & .15 & .15 \\
\hline Rhodium & .91 & .93 & .90 & .92 \\
\hline Palladium & .32 & .33 & .34 & .35 \\
\hline Gold & 2.19 & 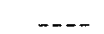 & 2.28 & $-\ldots$ \\
\hline Silver & .14 & & .14 & \\
\hline Iron & 8.20 & 8.40 & 8.13 & 8.33 \\
\hline Copper _- & .41 & .42 & .39 & .40 \\
\hline Nickel _- & Trace & Trace & Trace & Trace \\
\hline Arsenic & .03 & .03 & .04 & .04 \\
\hline Sulfur & .09 & .09 & .11 & .11 \\
\hline Chromite and silica & .11 & .11 & .18 & .19 \\
\hline \multicolumn{5}{|l|}{ Oxygen and } \\
\hline $\begin{array}{l}\text { undetermined } \\
\text { elements }\end{array}$ & 1.41 & 1.44 & 1.40 & 1.44 \\
\hline 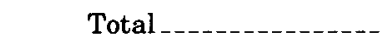 & 100.00 & 100.00 & 100.00 & 100.00 \\
\hline
\end{tabular}

$A_{1}, B_{1}$, recomputed free of gold and silver. 
of 20 granules of the principal alloy, choosing under high magnification those with uniformly smooth surfaces devoid of cracks, cavities, or external signs of adhering intergrowths. These eight granules were separately dissolved in aqua regia, and after decanting, the residues were dried and studied in order to establish approximately the proportion of osmiridium in the sample and to identify the included minerals. The eight solutes were then combined and analyzed. The weighted mean values of the resulting fractions were found to be those shown below:

Soluble platinum group metals

Soluble base metals

Insoluble platinum group metals --_-_- 1.15

Insoluble base minerals _.......... 2.53

The insoluble metals and minerals proved to be of great interest, as they included osmiridium and 11 mineral species. The components identified microscopically are listed below:

Osmiridium. Irregular grains up to $0.3 \mathrm{~mm}$ in size with some brilliant hexagonal plates, both separate and as complex growths. A few grains were attached to crystals of enstatite; a few grains occur in tiny veinlets.

Enstatite. In grains up to $0.7 \mathrm{~mm}$ in size.

Chromite. Several brilliant octahedra and a lesser number of complete or nearly complete crystals with somewhat dull facets and fragments.

Rutile. One good crystal and some fragments.

Tremolite. One group of transparent colorless acicular crystals.

Epidote. One perfect brilliant dark-greenish-black crystal, $0.12 \mathrm{~mm}$ long and $0.055 \mathrm{~mm}$ thick. Verified by interfacial angles.

Spinel. Several brilliant flattened crystals, blue or green by transmitted light. One opaque reddishbrown octahedron, slightly modified by the cube.

Sphene. One tan-colored perfect crystal.

Diamond. A perfect dodecahedron with curved faces, dark reddish black, and $0.081 \mathrm{~mm}$ in size. Also a transparent pale straw-colored octahedron $0.093 \mathrm{~mm}$ in size, modified by the cube.

Tourmaline. One singly terminated brilliant darkgreen crystal.

Topaz. Straw-colored fragments.

Corundum. One dark-blue crystal found in a different sample.

The five platinum minerals that have been identified, the two types of osmiridium intergrown with the principal alloy, and the 11 minerals that occur as inclusions clearly show the complexity of these platinum alloys.
SPECIAL CHEMICAL INVESTIGATIONS

A fundamental problem in chemical investigations is the composition of the two alloys. In 1943 John Cochrane made an attempt to solve this problem. His method was based upon the premise that the principal alloy consisted solely of the four cubic metals, platinum, iridium, rhodium, and palladium, all of which could be dissolved in hot aqua regia. On the other hand, he believed that platinum, iridium, and rhodium, when alloyed with the hexagonal metals osmium and ruthenium, constituted a completely insoluble mixture. If true, this would have provided an elegant method for separating the two alloys and for determining their compositions. It was necessary merely to dissolve the placer metals and to analyze separately the solute and the insoluble residue. This is not literally true, but it is sufficiently close to the truth that its application, as proposed and utilized, yielded very valuable information.

The Goodnews Bay Mining Co. dredge, working upstream in the valley floor of the Salmon River in 1943, was operated on the upper (northern) end of claim 6B, throughout the length of claim $5 \mathrm{~B}$, and on the lower (southern) end of claim $4 \mathrm{~B}$, at a mean distance of about 6,000 feet downstream from the mouth of Platinum Creek (fig. 4). Samples were taken of the 24 cleanups made within this stretch, of which the soluble and insoluble fractions were analyzed separately. During the same period, a dragline excavator was working on the upper (northern) end of the bench pay streak, opposite the mouth of Dowry Creek and east of claim 9A. The 15 cleanups of this operation were similarly sampled and analyzed. Thus 78 superior analyses were made, which, recomputed free of gold and impurities, are shown in tables $5,6,7$, and 8 . The symbols $S$ and $I$, shown in tables 5 and 7 , refer to the weights of the metals recovered in the soluble and insoluble fractions.

The operating sites of the dredge and dragline excavator were fortunately located. The metals recovered by the dredge were derived dominantly from the valley of Platinum Creek, with a smaller increment from the upper valley of the Salmon River upstream from the mouth of Platinum Creek. Hence this product represents mainly the platinum metals that came from bedrock at the southern end of the Red Mountain ridge. The metals recovered by the dragline excavator came almost entirely from the valleys of Dowry and Clara Creeks, or their ancestral predecessors, and therefore represented the platinum metals eroded from the northern end of the Red Mountain ridge. These two factors lend the greatest significance to these two sets of chemical analyses.

The Cochrane hypothesis implies that the principal 
TABLE 5.-Principal alloy, in percent, for dredge cleanups of 1943

\begin{tabular}{|c|c|c|c|c|c|}
\hline Cleanup No. & $\mathrm{Pt}$ & Ir & $\mathrm{Rh}$ & $\mathbf{P d}$ & $\begin{array}{c}\frac{S}{I} \text { ratio } \\
\text { (soluble: } \\
\text { insoluble) }\end{array}$ \\
\hline $\begin{array}{r}1 \\
1 \\
2\end{array}$ - & $\begin{array}{l}95.72 \\
95.70 \\
95.76 \\
95.92 \\
95.79 \\
95.96 \\
95.46 \\
95.93 \\
95.81 \\
95.79 \\
95.79 \\
95.55 \\
95.55 \\
95.50 \\
95.45 \\
95.61 \\
95.59 \\
95.63 \\
95.53 \\
95.59 \\
95.66 \\
95.73 \\
95.65 \\
95.67\end{array}$ & $\begin{array}{l}2.68 \\
2.63 \\
2.67 \\
2.58 \\
2.63 \\
2.53 \\
2.72 \\
2.49 \\
2.62 \\
2.67 \\
2.67 \\
2.70 \\
2.70 \\
2.86 \\
2.82 \\
2.81 \\
2.74 \\
2.85 \\
2.88 \\
2.86 \\
2.82 \\
2.86 \\
2.93 \\
2.89\end{array}$ & $\begin{array}{l}1.10 \\
1.11 \\
1.09 \\
1.12 \\
1.18 \\
1.05 \\
1.37 \\
1.13 \\
1.10 \\
1.10 \\
1.01 \\
1.25 \\
1.25 \\
1.17 \\
1.26 \\
1.12 \\
1.14 \\
1.04 \\
1.07 \\
1.09 \\
1.09 \\
.99 \\
1.00 \\
1.00\end{array}$ & $\begin{array}{l}0.50 \\
.50 \\
.48 \\
.38 \\
.40 \\
.46 \\
.45 \\
.45 \\
.47 \\
.44 \\
.53 \\
.50 \\
.50 \\
.47 \\
.47 \\
.46 \\
.53 \\
.48 \\
.52 \\
.46 \\
.43 \\
.42 \\
.42 \\
.44\end{array}$ & $\begin{array}{l}4.80 \\
5.15 \\
4.85 \\
4.46 \\
4.53 \\
4.59 \\
5.17 \\
4.90 \\
4.88 \\
5.16 \\
5.27 \\
5.70 \\
5.84 \\
6.34 \\
5.40 \\
5.44 \\
5.30 \\
5.82 \\
5.70 \\
6.39 \\
5.85 \\
5.29 \\
5.76 \\
5.60\end{array}$ \\
\hline Mean & 95.68 & 2.73 & 1.12 & .47 & 5.34 \\
\hline
\end{tabular}

TABLE 6.-Osmiridium alloy, in percent, for dredge cleanups of 1943

\begin{tabular}{|c|c|c|c|c|c|}
\hline Cleanup No. & $\mathrm{Pt}$ & Ir & Os & Ru & $\mathrm{Rh}$ \\
\hline $1 \ldots$ & 12.37 & 67.19 & 16.37 & 1.15 & 2.92 \\
\hline $2 \ldots$ & 10.70 & 68.43 & 16.45 & 1.21 & 3.21 \\
\hline $3-$ & 10.85 & 68.00 & 16.74 & 1.20 & 3.21 \\
\hline 4 -- & 10.59 & 68.21 & 16.86 & 1.24 & 3.10 \\
\hline $5 \ldots$ & 10.85 & 68.32 & 16.69 & 1.13 & 3.01 \\
\hline 6 & 11.41 & 69.36 & 14.94 & 1.22 & 3.07 \\
\hline $7--$ & 11.47 & 70.50 & 13.72 & 1.20 & 3.11 \\
\hline 8 -- & 10.85 & 68.19 & 16.61 & 1.14 & 3.21 \\
\hline 9 & 13.26 & 66.99 & 15.81 & 1.04 & 2.90 \\
\hline 10 & 12.01 & 68.55 & 15.30 & 1.21 & 2.93 \\
\hline 11 & 11.14 & 69.20 & 15.26 & 1.21 & 3.19 \\
\hline 12 & 9.55 & 70.19 & 15.52 & 1.22 & 3.52 \\
\hline 13 & 9.25 & 70.05 & 16.00 & 1.41 & 3.29 \\
\hline 14 & 10.84 & 68.28 & 16.43 & 1.13 & 3.32 \\
\hline 15 & 10.80 & 68.72 & 16.35 & 1.25 & 2.88 \\
\hline$\ldots$ & 10.06 & 69.23 & 16.60 & 1.25 & 2.86 \\
\hline 17 & 10.70 & 68.76 & 16.15 & 1.20 & 3.19 \\
\hline 18 & 11.71 & 66.46 & 17.03 & 1.22 & 3.58 \\
\hline 19 & 10.72 & 69.14 & 15.73 & 1.14 & 3.27 \\
\hline 20 & 11.29 & 66.47 & 17.52 & 1.18 & 3.54 \\
\hline 21 & 10.64 & 69.54 & 15.32 & 1.24 & 3.26 \\
\hline 22 & 11.01 & 68.62 & 16.16 & 1.14 & 3.07 \\
\hline 23 & 10.94 & 68.92 & 15.85 & 1.15 & 3.14 \\
\hline 24 & 10.87 & 68.46 & 16.40 & 1.05 & 3.22 \\
\hline Mean & 10.99 & 68.57 & 16.08 & 1.19 & 3.17 \\
\hline
\end{tabular}

alloy is composed of the four cubic platinum metals, with no osmium or ruthenium. It also implies that no platinum, iridium, or rhodium, which form a part of the osmiridium, can be dissolved by aqua regia, even on the
TABLE 7.-Principal alloy, in percent, for dragline excavator cleanups of 1943

\begin{tabular}{|c|c|c|c|c|c|}
\hline Cleanup No. & $\mathrm{Pt}$ & $\mathrm{Ir}$ & $\mathrm{Rh}$ & $\mathrm{Pd}$ & $\begin{array}{c}\frac{S}{I} \text { ratio } \\
\text { (Soluble: } \\
\text { Insoluble) }\end{array}$ \\
\hline $\begin{array}{r}1 \\
2 \\
3\end{array}$ & $\begin{array}{l}95.50 \\
95.52 \\
95.46 \\
95.45 \\
95.73 \\
95.67 \\
95.73 \\
95.45 \\
95.46 \\
95.41 \\
95.50 \\
95.57 \\
95.55 \\
95.79 \\
95.70\end{array}$ & $\begin{array}{l}2.92 \\
2.89 \\
2.94 \\
2.92 \\
2.73 \\
2.74 \\
2.72 \\
2.96 \\
2.98 \\
2.93 \\
2.94 \\
2.91 \\
2.93 \\
2.75 \\
2.77\end{array}$ & $\begin{array}{l}1.10 \\
1.11 \\
1.12 \\
1.19 \\
1.11 \\
1.10 \\
1.06 \\
1.10 \\
1.07 \\
1.17 \\
1.07 \\
1.05 \\
1.04 \\
0.97 \\
1.05\end{array}$ & $\begin{array}{l}0.48 \\
.48 \\
.48 \\
.44 \\
.43 \\
.49 \\
.49 \\
.49 \\
.49 \\
.49 \\
.49 \\
.47 \\
.48 \\
.49 \\
.48\end{array}$ & $\begin{array}{r}12.94 \\
11.80 \\
12.39 \\
9.71 \\
13.67 \\
13.57 \\
13.04 \\
11.20 \\
11.38 \\
13.08 \\
12.77 \\
11.81 \\
11.99 \\
12.32 \\
12.63\end{array}$ \\
\hline Mean ------- & 95.56 & 2.87 & 1.09 & .48 & 12.29 \\
\hline
\end{tabular}

TABLE 8.-Osmiridium alloy, in percent, for dragline excavator cleanups of 1943

\begin{tabular}{|c|c|c|c|c|c|}
\hline Cleanup No. & Pt & Ir & Os & $\mathrm{Ru}$ & $\mathrm{Rh}$ \\
\hline $\begin{array}{r}1 \\
2 \\
2\end{array} 2$ & $\begin{array}{l}10.84 \\
10.91 \\
10.97 \\
11.90 \\
11.65 \\
11.57 \\
11.92 \\
10.76 \\
11.06 \\
11.45 \\
11.99 \\
10.35 \\
10.40 \\
11.09 \\
11.28\end{array}$ & $\begin{array}{l}67.94 \\
65.80 \\
65.56 \\
65.78 \\
65.05 \\
64.96 \\
65.19 \\
66.62 \\
66.81 \\
65.34 \\
64.80 \\
67.96 \\
68.22 \\
66.27 \\
66.00\end{array}$ & $\begin{array}{l}15.95 \\
18.05 \\
18.13 \\
16.98 \\
17.97 \\
18.18 \\
17.49 \\
18.07 \\
17.65 \\
18.12 \\
18.07 \\
16.66 \\
16.55 \\
17.63 \\
17.62\end{array}$ & $\begin{array}{l}1.28 \\
1.31 \\
1.22 \\
1.34 \\
1.17 \\
1.16 \\
1.27 \\
1.38 \\
1.26 \\
1.27 \\
1.09 \\
1.15 \\
1.17 \\
1.06 \\
1.24\end{array}$ & $\begin{array}{l}3.99 \\
3.93 \\
4.12 \\
4.00 \\
4.16 \\
4.13 \\
4.13 \\
3.17 \\
3.22 \\
3.82 \\
4.05 \\
3.88 \\
3.66 \\
3.95 \\
3.86\end{array}$ \\
\hline Mean & 11.21 & 66.15 & 17.54 & 1.23 & 3.87 \\
\hline
\end{tabular}

surficial faces of the placer grains. It is probable, however, that very small amounts of osmium and ruthenium may constitute a part of the principal alloy, occuring in complex phase relations. And it is unlikely that the cubic metals of the osmiridium are entirely unaffected by aqua regia, though undoubtedly most of them are immune to chemical solution. These aberrant factors cannot be exactly evaluated; nevertheless, the working hypothesis on which these analyses were made has yielded valuable information that could not otherwise have been obtained.

The overall tenors of platinum are known to increase and those of iridium to decrease moving upstream in the valley of the Salmon River. These facts are shown in table 22 and in figure 11 . The 25 analyses of the output from the dredge, even though they represent little more than a claim length, tend to show this same relation. 
The most significant result of this analytical work, however, is that the principal alloy and the osmiridium, for the outputs of both the dredge and the dragline excavator, tend toward two constant compositions that depart little from the mean values of the contained metals. This will be evident from a comparison of tables 5 and 6 with tables 7 and 8 . Therefore the only reasonable explanation for the differences in the bulk compositions of the platinum metals in the placers is that these represent different ratios of two alloys of nearly constant composition. This interpretation is corroborated by the S:I ratios in tables 5 and 7, which in turn, explains the changes in the composition of the platinum metals from south to north on the Red Mountain ridge, as discussed later on a quantitative basis.

Another specialized chemical investigation of these platinum metals was undertaken to learn whether the compositions of the two alloys might vary with granularity. For this purpose the Goodnews Bay Mining Co. provided the writer with a sample of 365.5 grams of the platinum metals recovered in 1945 from the northeastern part of Discovery claim, about opposite the mouth of Platinum Creek. This sample was screened into 14 fractions, ranging in size from grains larger than $3.96 \mathrm{~mm}$ to grains smaller than $0.06 \mathrm{~mm}$ in diameter; these fractions were weighed by John Cochrane (at that time Chief Chemist of Matthey-Bishop, Inc.). The largest fraction, No. VIII, weighing 90.9455 grams and consisting of grains $0.50-0.35 \mathrm{~mm}$ in diameter, was later divided magetically and electromagnetically into seven subfractions. Subfraction VIII-a, which was ferromagnetic, was separated by the use of a $2 \frac{1 / 2}{2}$ inch Dings alnico horseshoe magnet. Subfractions VIII-b to VIII-f were separated by the use of a large electromagnet, using currents of $0.042,0.084,0.126,0.167$, and 1.2 amperes. Subfraction VIII-g was the residue not held by the electromagnet. Fraction VIII was therefore not analyzed directly; its composition was computed indirectly from its seven subfractions. Unlike commercial analyses, the parts of each fraction and subfraction that were soluble and insoluble in aqua regia were analyzed separately in order to secure all the data that were possibly obtainable. Thus 40 superior analyses were made by C. J. Johnson, a chemist employed by Matthey-Bishop, Inc.; the cost was born jointly by the Goodnews Bay Mining Co. and Matthey-Bishop, Inc. The results of this work are shown in table 9 . As the gold and impurities have very little significance in the conclusions drawn from these analyses, they were eliminated by a recomputation of the platinum metals alone, as show in table 10 .

A recomputation of table 9 from percentages to grams reveals that the greatest volume of platinum, rhodium, and palladium and also of the metals of the solute $(S)$ occurs in fraction VIII, in grains or aggregates with a mean diameter of $0.42 \mathrm{~mm}$; the corresponding weights are $67.0996,1.0913,0.3092$, and 68.7475 grams. On the other hand, the volumetric maxima for iridium, osmium, and ruthenium and those for the metals insoluble in aqua regia $(I)$ occur in fraction IX, in grains or aggregates with a mean diameter of $0.30 \mathrm{~mm}$; the weights are respectively $11.2955,2.3614,0.1653$, and 14.1764 grams. As platinum, rhodium, and palladium represent approximately the principal alloy and iridium, osmium, and ruthenium constitute a major part of the osmiridium, it follows that the grains and aggregates of the principal alloy are appreciably larger than those of the osmiridium. Another feature of interest is that most of the gold occurs in fraction VII, with a mean diameter of $0.60 \mathrm{~mm}$. Hence the grains of gold are larger than the grains or aggregates of the platinum metals, although this is not necessarily true throughout both pay streaks.

Recomputed values (table 10) show marked but irregular variations in the composition of the platinum metals with regard to granularity, notably in fractions II, III, XII, XIII, and XIV. These aberrations are related to the parameter $K=S / I$ and indicate clearly that these fractions contain abnormal additions of osmiridium. Such increments are too large to be regarded as haphazard, but the reason for their existence is unknown. It is apparent, however, from the contents of metals in the other fractions that no distinct correlation exists between composition and granularity other than in the discrepancies caused by irregular increments of osmiridium.

The magnetic subfractions of fraction VIII, given in table 9 as percentages, have been recomputed to grams in order to clarify certain relations and are shown in table 11.

This recomputation shows that only 4.3 percent of the platinum and 4.1 percent of the palladium are in the ferromagnetic subfraction VIII-a. The largest volumes of platinum and palladium are in subfractions VIII-c and VIII-d, which have a fairly strong paramagnetism commensurate with the magnetic susceptibilities of these two metals. Obviously, therefore, the ferromagnetism of fraction VIII-a results from a large number of inclusions of magnetite. Subfractions VIII-d, VIII-e, VIII-f, and VIII-g show decreasing paramagnetism owing to the progressive elimination of the principal alloy by magnetic action. Subfraction VIII-g is accepted as the most probable composition of the osmiridium contained in the screened sample shown in table 10 . The reasons for this interpretation are the low paramagnetism, the high content of iridium, the low content of platinum, and the total absence of palladium. The 
TABLE 9.-Analyses, in percent except as indicated, of screened IAnalyst, C. J. Johnson,

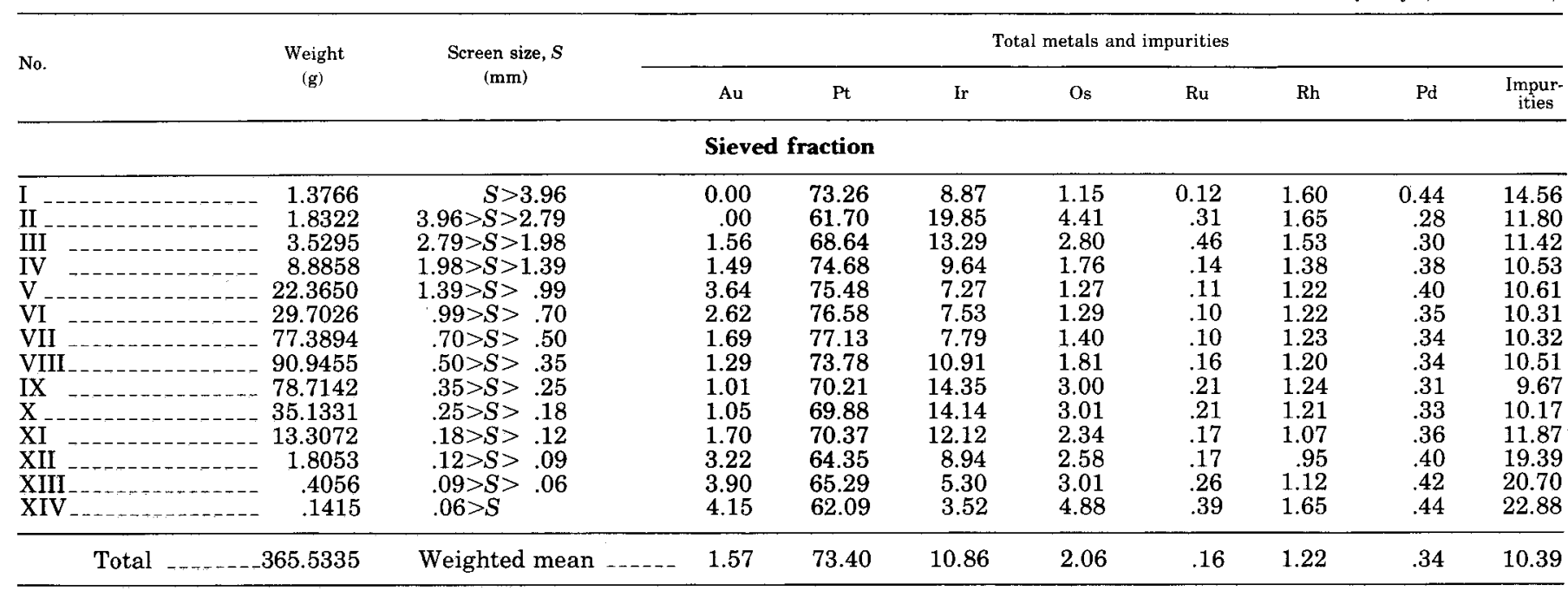

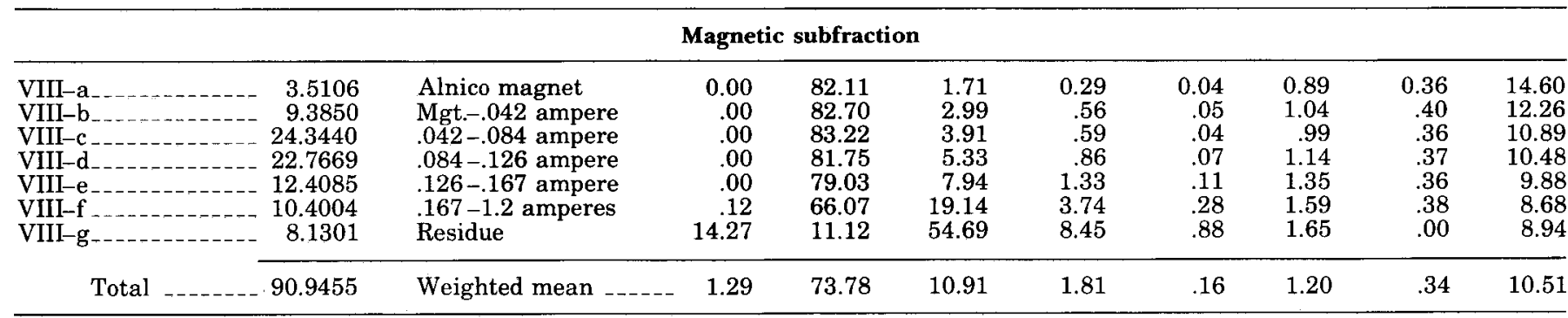

TABLE 10. Screened sample of platinum metals, recomputed free of gold and impurities, Discovery claim, Salmon River

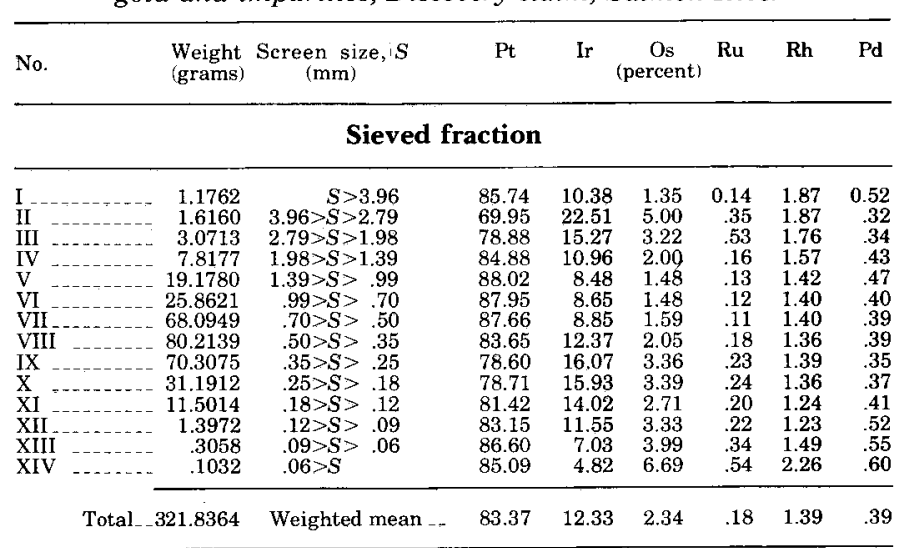

Magnetic subfraction

\begin{tabular}{|c|c|c|c|c|c|c|c|c|}
\hline VIII-a & $\ldots \ldots . . .2 .9981$ & Alnico magnet & 96.15 & 2.00 & 0.34 & 0.05 & 1.04 & 0.42 \\
\hline $\begin{array}{l}\text { VIII-b } \\
\text { VIII-c }\end{array}$ & $\begin{array}{r}8.2344 \\
21.6929\end{array}$ & $\begin{array}{l}\text { Mgt-. } 042 \text { ampere } \\
.042-.084 \text { ampre }\end{array}$ & $\begin{array}{l}94.23 \\
93.39\end{array}$ & $\begin{array}{l}3.41 \\
4.39\end{array}$ & $\begin{array}{l}.64 \\
66\end{array}$ & $\begin{array}{l}.06 \\
.05\end{array}$ & $\begin{array}{l}1.18 \\
1.11\end{array}$ & $\begin{array}{l}.48 \\
.40\end{array}$ \\
\hline VIII-d & 20.3809 & $.084-.126$ ampere & 91.32 & 5.96 & .96 & .08 & 1.27 & .41 \\
\hline VIII-e & 11,1825 & $.126 \ldots 1$ & 87.69 & 8.81 & 1.48 & .12 & 1.50 & .40 \\
\hline VIII- $f$ & 9.48 & $.167-1.2$ amperes & 14 & 20.99 & 4.10 & .31 & 1.74 & .42 \\
\hline VIII-g & 6.2431 & Residue & 14.48 & 71.22 & 11.00 & 1.15 & 2.15 & .00 \\
\hline & & Weight & 83.64 & 12.38 & 2.0 & .18 & 1.37 & .38 \\
\hline
\end{tabular}

metallic content of subfraction VIII-g and of its soluble and insoluble parts, recomputed to grams, are presented in table 12. This table shows clearly that parts of the
TABLE 11.-Magnetic subfractions, in grams, of fraction VIII

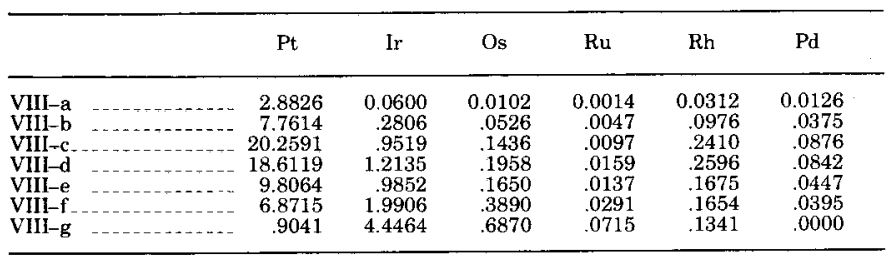

TABLE 12.-Chemical data, in grams, of subfraction VIII-g

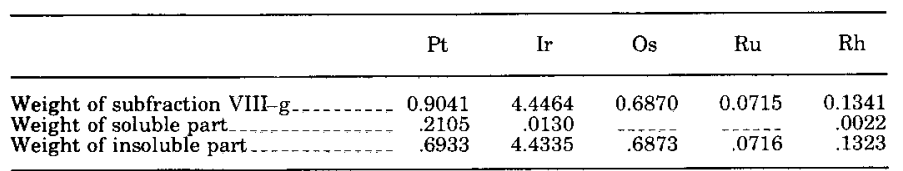

platinum, iridium, and rhodium are dissolved by aqua regia, the dissolved parts constituting, respectively, $23.3,0.3$, and 1.6 percent, supporting the interpretation that the soluble part of any sample represents only approximately the composition of the principal alloy. It follows that certain percentages of platinum, iridium, and rhodium derived by partial solution of the osmiridium must be subtracted from the soluble part of any sample in order to obtain the composition of the principal alloy. Thereafter the metallic content may be recomputed to total 100 percent.

Theoretically, the composition of the principal alloy 
sample of platinum metals, Discovery claim, Salmon River Matthey-Bishop, Inc.]

\begin{tabular}{|c|c|c|c|c|c|c|c|c|c|c|c|c|c|}
\hline \multicolumn{5}{|c|}{ Soluble $(S)$ and insoluble $(I)$} & \multicolumn{4}{|c|}{ Soluble } & \multicolumn{5}{|c|}{ Insoluble } \\
\hline$S$ & $I$ & $\operatorname{Drose}_{s}$ & Dross $_{i}$ & $\frac{\mathrm{K}}{(\mathrm{S} / I)}$ & $\mathrm{Pt}$ & Ir & $\mathrm{Rh}$ & $\mathrm{Pd}$ & Pt & Ir & Os & $\mathrm{Ru}$ & $\mathrm{Rh}$ \\
\hline \multicolumn{14}{|c|}{ Sieved fraction } \\
\hline $\begin{array}{l}80.73 \\
63.08 \\
70.00 \\
77.09 \\
77.76 \\
79.04 \\
79.60 \\
75.59 \\
71.31 \\
70.73 \\
71.23 \\
64.21 \\
64.29 \\
60.96\end{array}$ & $\begin{array}{r}4.71 \\
25.12 \\
17.02 \\
10.89 \\
7.99 \\
8.03 \\
8.39 \\
12.61 \\
18.01 \\
18.05 \\
15.22 \\
13.18 \\
11.11 \\
12.01\end{array}$ & $\begin{array}{r}10.27 \\
7.52 \\
8.28 \\
9.10 \\
9.22 \\
9.28 \\
9.51 \\
9.06 \\
8.72 \\
8.85 \\
9.87 \\
12.51 \\
12.41 \\
13.62\end{array}$ & $\begin{array}{r}4.29 \\
4.28 \\
3.14 \\
1.43 \\
1.39 \\
1.03 \\
.81 \\
1.45 \\
.95 \\
1.32 \\
1.98 \\
6.88 \\
8.29 \\
9.26\end{array}$ & $\begin{array}{r}17.140 \\
2.511 \\
4.113 \\
7.079 \\
9.732 \\
9.843 \\
9.487 \\
5.994 \\
3.959 \\
3.919 \\
4.680 \\
4.872 \\
5.787 \\
5.076\end{array}$ & $\begin{array}{l}90.18 \\
93.58 \\
95.01 \\
95.32 \\
95.92 \\
95.79 \\
95.78 \\
95.72 \\
95.95 \\
95.97 \\
96.18 \\
96.50 \\
96.72 \\
96.75\end{array}$ & $\begin{array}{l}7.66 \\
4.65 \\
3.23 \\
2.88 \\
2.37 \\
2.63 \\
2.65 \\
2.79 \\
2.58 \\
2.54 \\
2.38 \\
2.10 \\
1.71 \\
1.38\end{array}$ & $\begin{array}{r}1.62 \\
1.33 \\
1.33 \\
1.31 \\
1.20 \\
1.14 \\
1.14 \\
1.04 \\
1.04 \\
1.02 \\
.93 \\
.78 \\
.92 \\
1.15\end{array}$ & $\begin{array}{l}0.54 \\
.44 \\
.43 \\
.49 \\
.51 \\
.44 \\
.43 \\
.45 \\
.43 \\
.47 \\
.51 \\
.62 \\
.65 \\
.72\end{array}$ & $\begin{array}{r}9.77 \\
10.63 \\
12.51 \\
11.02 \\
11.14 \\
10.83 \\
10.61 \\
11.25 \\
9.94 \\
11.08 \\
12.22 \\
18.13 \\
27.99 \\
25.90\end{array}$ & $\begin{array}{l}57.11 \\
67.36 \\
64.81 \\
68.14 \\
67.96 \\
67.87 \\
67.70 \\
69.86 \\
69.46 \\
68.37 \\
68.46 \\
57.59 \\
37.81 \\
22.31\end{array}$ & $\begin{array}{l}24.41 \\
17.56 \\
16.45 \\
16.16 \\
15.89 \\
16.06 \\
16.69 \\
14.33 \\
16.66 \\
16.68 \\
15.37 \\
19.58 \\
27.09 \\
40.63\end{array}$ & $\begin{array}{l}2.55 \\
1.23 \\
2.70 \\
1.28 \\
1.38 \\
1.25 \\
1.19 \\
1.27 \\
1.16 \\
1.16 \\
1.12 \\
1.29 \\
2.34 \\
3.25\end{array}$ & $\begin{array}{l}6.16 \\
3.22 \\
3.53 \\
3.40 \\
3.63 \\
3.99 \\
3.81 \\
3.29 \\
2.78 \\
2.71 \\
2.83 \\
3.41 \\
4.77 \\
7.91\end{array}$ \\
\hline 75.17 & 12.88 & 9.13 & 1.25 & 5.836 & 95.79 & 2.67 & 1.09 & .45 & 10.82 & 68.76 & 16.02 & 1.23 & 3.17 \\
\hline \multicolumn{14}{|c|}{ Magnetic subfraction } \\
\hline $\begin{array}{r}84.61 \\
85.67 \\
86.05 \\
84.80 \\
82.52 \\
67.48 \\
2.77\end{array}$ & $\begin{array}{r}0.79 \\
2.07 \\
3.06 \\
4.72 \\
7.60 \\
23.72 \\
74.02\end{array}$ & $\begin{array}{r}12.78 \\
10.75 \\
10.35 \\
9.91 \\
9.32 \\
7.75 \\
.54\end{array}$ & $\begin{array}{r}1.82 \\
1.51 \\
.54 \\
.57 \\
.56 \\
.93 \\
8.40\end{array}$ & $\begin{array}{r}107.101 \\
41.386 \\
28.121 \\
17.966 \\
10.858 \\
2.845 \\
.037\end{array}$ & $\begin{array}{l}96.81 \\
96.17 \\
96.36 \\
95.86 \\
94.85 \\
93.79 \\
93.50\end{array}$ & $\begin{array}{l}1.95 \\
2.37 \\
2.28 \\
2.63 \\
3.49 \\
4.45 \\
5.78\end{array}$ & $\begin{array}{r}0.82 \\
.99 \\
.94 \\
1.07 \\
1.22 \\
1.20 \\
.72\end{array}$ & $\begin{array}{r}0.42 \\
.47 \\
.42 \\
.44 \\
.44 \\
.56 \\
.00\end{array}$ & $\begin{array}{r}25.32 \\
14.98 \\
9.80 \\
9.75 \\
10.00 \\
11.72 \\
11.52\end{array}$ & $\begin{array}{r}7.59 \\
46.38 \\
63.73 \\
65.68 \\
66.58 \\
68.04 \\
73.67\end{array}$ & $\begin{array}{l}36.71 \\
27.05 \\
19.28 \\
18.22 \\
17.50 \\
15.77 \\
11.42\end{array}$ & $\begin{array}{l}5.06 \\
2.41 \\
1.31 \\
1.48 \\
1.45 \\
1.18 \\
1.19\end{array}$ & $\begin{array}{r}25.32 \\
9.18 \\
5.88 \\
4.87 \\
4.47 \\
3.29 \\
2.20\end{array}$ \\
\hline 75.59 & 12.61 & 9.06 & 1.45 & 5.994 & 95.72 & 2.79 & 1.04 & .45 & 11.25 & 69.86 & 14.33 & 1.27 & 3.29 \\
\hline
\end{tabular}

may be obtained by subtracting the weights of the metals of the osmiridium from those of the entire sample, after both have been recomputed to grams. For fraction VIII shown in table 10, this is impracticable because parts of the osmiridium are in subfractions VIII-a to VIII-f, inclusive, and these increments cannot be ascertained from the available chemical data. The best that can be done is to assume certain factors, which are first multiplied into the metals of subfraction VIII-g; thereafter, these products are subtracted from the corresponding values of fraction VIII, thus yielding several compositions, any one of which may closely represent the principal alloy. The factors that have been selected for this purpose are 1.6,1.7, 1.8, and 1.9, and the resulting possible compositions of the principal alloy are labeled respectively A, B, C, and D in table 13 .

The stated factors were chosen because they yield values for platinum and iridium of the correct order of

TABLE 13.-Computation of principal alloy, fraction VIII

\begin{tabular}{|c|c|c|c|c|c|c|}
\hline & \multirow[b]{2}{*}{$\begin{array}{c}\text { VIII } \\
\text { (grams) }\end{array}$} & \multirow[b]{2}{*}{$\begin{array}{c}\text { VIII-g } \\
\text { (grams) }\end{array}$} & \multicolumn{4}{|c|}{$\begin{array}{l}\text { Possible composition, in percent } \\
\text { (computation factor) }\end{array}$} \\
\hline & & & $\begin{array}{c}\mathrm{A} \\
1.6\end{array}$ & $\underset{1.7}{B}$ & $\begin{array}{c}C \\
1.8\end{array}$ & $\begin{array}{l}D \\
1.9\end{array}$ \\
\hline Platinum & 67.0996 & 0.9041 & 93.49 & 94.20 & 94.92 & 95.96 \\
\hline Iridium & 9.9222 & 4.4464 & 4.00 & 3.40 & 2.78 & 2.16 \\
\hline Osmium & 1.6461 & .6870 & .78 & .68 & .59 & .50 \\
\hline Ruthenium & .1455 & .0715 & .04 & .03 & .02 & .01 \\
\hline Rhodium & 1.0913 & .1341 & 1.25 & 1.24 & 1.23 & 1.22 \\
\hline Palladium & .3092 & $-\ldots-$ & .44 & .45 & .46 & .46 \\
\hline
\end{tabular}

magnitude, after the decrements of platinum, iridium, and rhodium, dissolved from the osmiridium, have been subtracted from the values of the fraction VIII. From these possible compositions, it follows that small contents of osmium and ruthenium constitute an integral part of the principal alloy.

The parameter $K=S / I$ was obtained originally from the weights of the soluble and insoluble parts of each of the fractions and subfractions that resulted from screening or magnetic separation. It may also be obtained from the percentages of the total, soluble, and insoluble parts of any one of the six platinum metals by the following method.

Let $W$ be the weight of any fraction or subfraction and $A$ and $B$ be the weights of its soluble and insoluble parts. It is obvious that $A=K W / K+1$ and $B=W / K+1$. Now let $X_{\mathrm{t}}$ represent the percentage of a specified platinum metal in one of the fractions or subfractions shown in table 10 and $X_{\mathrm{s}}$ and $X_{i}$ the corresponding percentages of the soluble and insoluble parts of this metal shown in table 9 . The following identities then apply:

$W X_{t}=$ weight of the specified metal in the given sample,

$$
\begin{aligned}
& \frac{K W}{K+1} \cdot X_{s}= \text { weight of soluble fraction, same } \\
& \text { metal, and } \\
& \frac{W}{K+1} \cdot X_{i}= \text { weight of insoluble fraction, same } \\
& \text { metal. }
\end{aligned}
$$


Thus,

$$
W X_{t}=\frac{K W}{K+1} \cdot X_{s}+\frac{W}{K+1} \cdot X_{i}
$$

Eliminating $W$, we have

$$
X_{t}=\frac{K X_{s}}{K+1}+\frac{X_{i}}{K+1}
$$

whence

$$
K=\frac{X_{t}-X_{i}}{X_{s}-X_{t}}
$$

\section{PLATINUM PLACERS}

ANALYTICAL DATA

The volume, distribution, composition, and grain sizes of the precious metals found as placer deposits in the Goodnews Bay district are of great significance in determining the character and occurrence of these metals in their bedrock sources. Similar data on the platinum lodes are critical to an understanding of the mineralization and the discovery of new workable deposits. As few such data have been published, the economic geology of the platinum metals is therefore less well understood than that of many other metalliferous ores. The Goodnews deposits are unique in that the owners have made available for publication all the pertinent analytic and related data on these placers.

The data made available include 710 screen analyses of the cleanups for the period 1938-70, except for the years $1940-41$, which are missing, and 995 superior chemical analyses of the platinum metals, including duplicates by different analysts. Matthey-Bishop, Inc. made 871 of these analyses; the remainder were made by other concerns. To these should be added the 59 double analyses (soluble and insoluble fractions) recorded under special chemical investigations, 20 by Matthey-Bishop, Inc. and 39 by John Cochrane. A great deal of collateral information has been acquired from conferences with the owners and employees of the company.

The numerical data are too numerous to permit their complete tabulation or charting, but it is feasible to represent them collectively by claims, in order downstream. On the bench of the Salmon River, however, this scheme was somewhat modified, as the dimensions and orientation of the bench claims differ from those of the valley floor. Hence a system of consecutive "units" was devised whose longitudinal or north-south limits correspond approximately with the claim lengths of the valley floor. These two collective modes of presentation are more useful for genetic interpretations, as minor variations and errors tend to cancel one another.

The tabulations presented are arithmetic means of the screen and chemical analyses. The original data for granularity are in ounces and fractions thereof, but the chemical analyses are in percentages. Accurate mean values cannot be obtained by averaging percentages arithmetically or by any method other than by weighting. But weighting is not possible for the analytical data, as the weights of the individual shipments are not known. However, the weights of the cleanups taken at regular intervals are not very aberrant, and the character of the metals does not change greatly from claim to claim. And as the weights of the shipments to the refiner, where the analyses are made, are of the same order of magnitude, weighting of the analyses is not so urgently needed. For these reasons, it is believed that the mean values obtained from unweighted tabulations are not greatly in error.

Annual production data for the years 1936-72 have been made available by the Goodnews Bay Mining Co. These data, though presented as percentages, are based upon actual weights of the six platinum metals, gold, and impurities and are therefore accurate. This information, computed into a form suitable for publication, is presented in three forms of table 14.

TABLE 14.-Percentages of platinum metals, gold, and impurities,

\begin{tabular}{|c|c|c|c|c|c|c|c|c|}
\hline Year & $\mathbf{P t}$ & Ir & $O s$ & $\mathrm{Ru}$ & $\mathrm{Rh}$ & $\mathrm{Pd}$ & $\mathrm{Au}$ & $\underset{\text { ities }}{\text { Impur- }}$ \\
\hline $\begin{array}{l}1936 \\
1937 \\
1938 \\
1940 \\
1941 \\
1942\end{array}$ & $\begin{array}{l}68.39 \\
64.95 \\
72.19 \\
71.54 \\
71.77 \\
72.44 \\
72.50 \\
74.68 \\
74.67 \\
73.09 \\
76.24 \\
77.25 \\
77.47 \\
76.86 \\
75.46 \\
75.26 \\
73.23 \\
71.57 \\
73.31 \\
74.39 \\
76.19 \\
75.39 \\
75.03 \\
75.22 \\
75.64 \\
76.19 \\
76.16 \\
71.83 \\
69.42 \\
69.80 \\
67.62 \\
67.51 \\
66.14 \\
67.47 \\
68.41 \\
71.41 \\
68.26\end{array}$ & $\begin{array}{r}12.72 \\
17.29 \\
11.24 \\
12.26 \\
12.34 \\
1.05 \\
10.37 \\
9.39 \\
9.65 \\
10.30 \\
7.61 \\
5.83 \\
6.20 \\
7.07 \\
9.13 \\
9.33 \\
11.10 \\
12.19 \\
10.91 \\
9.83 \\
8.27 \\
8.26 \\
7.96 \\
7.88 \\
7.85 \\
7.42 \\
7.22 \\
10.18 \\
11.92 \\
12.26 \\
12.89 \\
12.60 \\
13.55 \\
12.63 \\
10.94 \\
9.38 \\
13.87\end{array}$ & $\begin{array}{l}3.24 \\
3.29 \\
2.24 \\
2.57 \\
2.56 \\
2.22 \\
2.14 \\
1.75 \\
1.82 \\
2.07 \\
1.42 \\
.94 \\
1.01 \\
1.22 \\
1.59 \\
1.76 \\
2.15 \\
2.45 \\
2.02 \\
1.76 \\
1.10 \\
1.42 \\
1.25 \\
1.40 \\
1.34 \\
1.28 \\
1.25 \\
1.93 \\
2.38 \\
2.41 \\
2.56 \\
2.59 \\
2.72 \\
2.35 \\
2.06 \\
1.71 \\
2.53\end{array}$ & $\begin{array}{l}0.24 \\
.29 \\
.17 \\
.20 \\
.19 \\
.20 \\
.16 \\
.13 \\
.14 \\
.16 \\
.10 \\
.07 \\
.08 \\
.10 \\
.14 \\
.14 \\
.18 \\
.19 \\
.17 \\
.16 \\
.10 \\
.11 \\
.11 \\
.11 \\
.11 \\
.10 \\
.10 \\
.15 \\
.19 \\
.19 \\
.19 \\
.18 \\
.19 \\
.19 \\
.17 \\
.14 \\
.23\end{array}$ & $\begin{array}{r}1.46 \\
1.85 \\
.99 \\
1.16 \\
1.16 \\
1.14 \\
1.31 \\
1.21 \\
1.21 \\
1.31 \\
1.12 \\
1.01 \\
1.04 \\
1.14 \\
1.23 \\
1.28 \\
1.80 \\
1.21 \\
1.19 \\
1.31 \\
1.16 \\
1.12 \\
.98 \\
.95 \\
.89 \\
.96 \\
.96 \\
.98 \\
1.00 \\
1.01 \\
1.04 \\
.98 \\
1.09 \\
1.19 \\
1.10 \\
1.09 \\
1.21\end{array}$ & $\begin{array}{l}0.23 \\
.25 \\
.29 \\
.31 \\
.32 \\
.31 \\
.36 \\
.36 \\
.37 \\
.34 \\
.39 \\
.38 \\
.39 \\
.38 \\
.35 \\
.33 \\
.31 \\
.34 \\
.38 \\
.37 \\
.38 \\
.33 \\
.32 \\
.36 \\
.37 \\
.37 \\
.33 \\
.29 \\
.29 \\
.28 \\
.27 \\
.33 \\
.32 \\
.35 \\
.36 \\
.33\end{array}$ & $\begin{array}{l}0.45 \\
1.08 \\
1.69 \\
1.63 \\
1.80 \\
2.01 \\
2.73 \\
2.19 \\
2.13 \\
2.16 \\
2.91 \\
3.73 \\
2.83 \\
2.54 \\
1.64 \\
1.43 \\
1.32 \\
1.46 \\
1.37 \\
1.69 \\
1.57 \\
1.70 \\
1.70 \\
1.98 \\
1.54 \\
1.68 \\
1.82 \\
2.52 \\
3.11 \\
3.34 \\
3.85 \\
4.17 \\
4.26 \\
4.02 \\
4.90 \\
3.76 \\
1.60\end{array}$ & $\begin{array}{r}13.27 \\
11.01 \\
11.19 \\
10.33 \\
9.86 \\
10.63 \\
10.43 \\
10.29 \\
10.01 \\
10.57 \\
10.21 \\
10.79 \\
10.98 \\
10.69 \\
10.46 \\
10.45 \\
10.39 \\
10.62 \\
10.69 \\
10.48 \\
11.24 \\
11.62 \\
12.64 \\
12.14 \\
12.27 \\
12.00 \\
12.12 \\
12.08 \\
11.69 \\
11.60 \\
11.57 \\
11.70 \\
11.72 \\
11.83 \\
12.07 \\
12.15 \\
11.97\end{array}$ \\
\hline $\begin{array}{c}\text { Weighted } \\
\text { mean, A } \\
\text { Weighted } \\
\text { mean, B } \\
\text { Weighted } \\
\text { mean, C }\end{array}$ & $\begin{array}{l}73.27 \\
82.25 \\
84.30\end{array}$ & $\begin{array}{l}10.08 \\
11.32 \\
11.60\end{array}$ & $\begin{array}{l}1.92 \\
2.15 \\
2.21\end{array}$ & $\begin{array}{l}.15 \\
.17 \\
.18\end{array}$ & $\begin{array}{l}1.15 \\
1.30 \\
1.32\end{array}$ & $\begin{array}{l}.34 \\
.38 \\
.39\end{array}$ & $\begin{array}{l}2.17 \\
2.43 \\
----\end{array}$ & $\begin{array}{r}10.92 \\
--- \\
---\end{array}$ \\
\hline
\end{tabular}
Goodnews Bay district [Based on data from Goodnews Bay Mining Co.]

A. Platinum metals, gold, and impurities.

C. Recomputed free of gold and impurities. 
SIEVE AND CHEMICAL ANALYSES

Sieve analyses are available only of the precious metals recovered from the placers of the Salmon River. Of these, 308 represent cleanups from the valley floor, and 402 represent cleanups from the bench pay streak. Most of these were screened through sieves of sizes 12 , $14,20,28,35$, and 48 , yielding mean sizes of $>1.40$, $1.28,1.00,0.71,0.50,0.36$, and $<0.30 \mathrm{~mm}$ respectively; a few cleanups were run through 6 and 8 mesh screens. Numerous cleanups were screened through a 100-mesh sieve with an aperture of $0.15 \mathrm{~mm}$. In such cases the mean sizes smaller than $0.030 \mathrm{~mm}$ are 0.22 and $<0.15 \mathrm{~mm}$. In this paper, the grain sizes are tabulated and charted in three sizes: grains of $0.83 \mathrm{~mm}$ diameter and larger, grains smaller than $0.83 \mathrm{~mm}$ and larger than $0.42 \mathrm{~mm}$, and grains smaller than $0.42 \mathrm{~mm}$, designated respectively as coarse, medium, and fine grains. The total range in sizes extends from $<0.15 \mathrm{~mm}$ to nuggets, of which the largest found weighed about 4 troy ounces (124.4 grams).

The mean values of 816 platinum analyses of samples from the valley of the Salmon River have been charted by claims and units for the years 1937-70. Of these, 404 represent platinum metals from the pay streak of the valley floor, and 412 platinum metals from the bench pay streak. Also tabulated are 26 analyses of samples of minus 100-mesh grain size $(<0.15 \mathrm{~mm}$ diameter), 9 from the valley floor and 17 from the bench. These 26 analyses cannot be consistently assigned to particular claims or units, as most of them represent accumulations of ultrafines later submitted separately for analysis. Weighted by the number of claims from which they were recovered, they must be added to the totals in order to obtain mean compositions.

\section{LOCALITIES OF PLACER DEPOSITS}

Platinum lodes have not been located in the Goodnews Bay district even though the bedrock source of all platinum placers is known to be the ultrabasic rocks of Red Mountain ridge by discovery of platinum placers in all the western headwater tributaries of the Salmon River that drain this ridge. No other tributaries of this river contain platinum metals. The streams draining the eastern slopes of Red Mountain are the fluvial conduits that have discharged all the platinum metals found in the valley of the Salmon River, as the valley floor of this river contains no bedrock that could be a source of these metals. For this reason, the placers of these headwater tributaries are described first, and their characteristics will yield a better understanding of both the placers of the Salmon River and their bedrock sources.

Two major paystreaks have been discovered and mined in the valley of the Salmon River. One of these, located on the valley floor, extends from the mouth of Clara Creek downstream for approximately 6 miles. Contributory pay streaks lie in the valleys of Platinum Creek and its tributaries and in Dowry and Clara Creeks. A small tributary between Squirrel and Dowry Creeks, known as First Chance Creek, contains some platinum in its valley but has no workable pay streak. The valley of McCann Creek, a tributary of the Smalls River, is also platiniferous but has no pay streak.

A second major pay streak, called the bench pay streak, lies in a depression along the eastern side of the valley of the Salmon River and has been mined from a point opposite the mouth of Dowry Creek downstream for about 4.4 miles. The lower or southeastern extension of this pay streak has not been mined, owing to the thickness of its overburden, but prospecting by drilling indicates that it may extend 4 miles farther downstream. Remnants of still higher and older fluvial deposits with small amounts of platinum are known to be present between Snow Gulch and Happy Creek.

TRIBUTARIES OF SALMON RIVER

Platinum Creek

Platinum Creek is a western tributary of the Salmon River having an air-line length of about 2 miles; it receives three tributaries from the north, in order downstream Fox Gulch, Dry Gulch, and Squirrel Creek. All are platiniferous, but Platinum Creek above the mouth of Fox Gulch is essentially barren of platinum metals. The valley of Platinum Creek may best be described in three units: upper Platinum Creek above the mouth of Squirrel Creek, Squirrel Creek, and the lower valley of Platinum Creek below the mouth of Squirrel Creek.

$$
\text { Fox Gulgh and Upper Platinum Creek }
$$

Fox Gulch heads in the ultrabasic rocks of Red Mountain; its pay streak has a length of about 2,600 feet extending downstream on Platinum Creek for another stretch of 3,300 feet. The early mining on Fox Gulch was done in 1927 to 1934, but the whole pay streak of Fox Gulch was reworked by a dragline excavator in 1937 and 1938; a small area at the head of the creek was worked in 1941. That part of the upper valley of Platinum Creek above the mouth of Dry Gulch was mined in 1938, but about 1,600 feet of the pay streak below the mouth of Dry Gulch was not worked at that time, as this stretch was then considered to be marginal ground. Dragline mining of this stretch began in 1968 at the mouth of Squirrel Creek and was continued upstream to the limit of workable ground.

The average width of the pay streak on Fox Gulch was about 75 feet, but variations in width and depth to bedrock have not been recorded. Downstream the pay 
streak became wider, ranging from 100 feet to as much as 200 feet at the mouth of Dry Gulch. The gravels of Fox Gulch, made up primarily of ultrabasic rocks, are large and subangular, averaging 8-12 inches in diameter, and include boulders as much as 3 feet in diameter. The character and depth of the overburden on Fox Gulch have not been recorded, but in the upper valley of Platinum Creek, the alluvium consists of approximately 12 feet of subrounded to subangular gravels overlain by 3 feet of colluvium and turf mixed locally with sand and eluvial material. These gravels, a mixture of ultrabasic intrusive rocks and sedimentary rocks, have an average diameter of 5-6 inches but include cobbles and boulders of larger size. The bedrock in the upper valley of Fox Gulch is predominantly ultrabasic rock, whereas the bedrock of the valley floor of upper Platinum Creek is mainly altered graywacke and sheared argillite alternating with lavas and tuffs of andesitic character.

The tenor in platinum metals was highest on Fox Gulch; the average tenor is not known. In one cleanup on Platinum Creek, however, a short distance below the mouth of Fox Gulch, a tenor of 0.03 ounce of platinum metals per cubic yard was recorded. Downstream on Platinum Creek, the tenors diminished, and in the early days of mining, the stretch from Dry Gulch to Squirrel Creek was not considered workable.

The platinum metals occur mainly on the surface and in the crevices of bedrock but are also present in the lower 3-4 feet of the overlying gravels. The higher gravels and other sediments contain little platinum. No record has been kept of the granularity of the precious metals; but those recovered from Fox Gulch and the upper valley of Platinum Creek are known to have been fairly fine grained, and nuggets were uncommon. Prior to 1937 , the largest nugget found weighed only a quarter of an ounce; larger ones were later recovered from other areas. Some nuggets were found to be intergrown with chromite.

Twenty-six analyses are available of the product recovered from the head of Fox Gulch to the mouth of Squirrel Creek. The exact sequence of the cleanups represented by these analyses has not been recorded, but six are known to represent the platinum metals recovered from the upper valley of Fox Gulch. The mean values of these 6 analyses and of 26 analyses from the area, together with two others showing maximum and minimum values of iridium, are shown in table 15. A significant characteristic of the values shown by table 15 is that the content of platinum increases downstream, whereas reciprocally the tenors of iridium, osmium, and ruthenium diminish downstream.

Sample E represents a bulk mixture of intergrowths of the principal alloy with osmiridium in a ratio not
TABLE 15.-Analyses, in percent, of precious metals, Fox Gulch and upper Platinum Creek

\begin{tabular}{|c|c|c|c|c|c|c|c|}
\hline & $\mathrm{Pt}$ & Ir & Os & Ru & $\mathrm{Rh}$ & $P d$ & $\mathrm{Au}$ \\
\hline $\begin{array}{l}\mathrm{A} \\
\mathrm{B} \\
\mathrm{C} \\
\mathrm{D} \\
\mathrm{E} \\
\mathrm{F}\end{array}$ & \begin{tabular}{c|c} 
& 50.56 \\
\hdashline & 50.61 \\
\hdashline & 63.71 \\
& 63.94 \\
\hdashline & 47.20 \\
&
\end{tabular} & $\begin{array}{l}39.14 \\
39.18 \\
28.01 \\
28.11 \\
41.06 \\
19.04\end{array}$ & $\begin{array}{l}7.74 \\
7.74 \\
5.39 \\
5.41 \\
8.41 \\
2.16\end{array}$ & $\begin{array}{r}0.71 \\
.71 \\
.47 \\
.48 \\
.84 \\
.22\end{array}$ & $\begin{array}{l}1.62 \\
1.62 \\
1.82 \\
1.83 \\
2.29 \\
2.09\end{array}$ & $\begin{array}{r}0.14 \\
.14 \\
.23 \\
.23 \\
.20 \\
.31\end{array}$ & $\begin{array}{r}0.09 \\
-.-37 \\
.37 \\
--- \\
--\end{array}$ \\
\hline
\end{tabular}

A. Mean value of six analyses of the product from the upper valley of Fox Gulch, recomputed free of impurities.

B. Same as A, recomputed free of gold and impurities.

C. Mean value of 26 analyses of the product from Fox Gulch and from Platinum Creek above the mouth of Squirrel Creek, recomputed free of impurities.

D. Same as C, recomputed free of gold and impuritie

the maximum content of iridium, osmium, and ruthe minimum content of platinum and mpurities.

F. Analysis from Platinum Creek, a short distance above the mouth of Squirrel Creek, showing maximum content of platinum and minimum content of iridium, osmium, and ruthenium, recomputed free of gold and impurities.

accurately determinable. This analysis shows a higher content of iridium, osmium, and ruthenium than any other sample within the Goodnews Bay district; the Ir:Os ratio is about $5: 1$, similar to that found by Cochrane for the more commonplace, or type B, osmiridium. But the content of platinum is about three times as great as that of pure osmiridium found elsewhere in the world. A rough calculation indicates that the ratio of the principal alloy to osmiridium in sample $E$ is about $1: 1$; the same ratio for sample $F$ is approximately $3: 1$.

The percentages of gold from Fox Gulch and the upper valley of Platinum Creek increase generally but not linearly downstream. The content of gold of the first 10 analyses range from a trace of 0.20 percent with a mean value of 0.05 percent. The next five analyses downstream show a range of $0.17-0.42$ percent with a mean value of 0.30 percent. And the last 11 analyses, extending to the mouth of Squirrel Creek, show a range of 0.44-1.05 percent with a mean value of 0.65 percent. The content of gold is not related genetically to that of the platinum metals, as the gold is not of local origin but instead is an alien constituent introduced by glaciation.

Squirrel Creek

Squirrel Creek, the principal tributary of Platinum Creek, has a length of approximately 1.6 miles. Heading in the Red Mountain ridge, about 1 mile from the head of Fox Gulch, this stream flows southeastward for about 0.7 mile, then turns southward and flows to Platinum Creek. This change in course is at the contact between the ultrabasic rocks of Red Mountain and the adjacent sedimentary rocks. The upper valley of Squirrel Creek is a narrow gulch; the lower valley, which contains the workable pay streak, is broad and open.

The gravels are similar to those of Platinum Creek, ranging from cobbles and boulders in the upper valley to smaller gravels in the pay streak, diminishing in size 
downstream. The petrographic character of the gravels in the lower valley is largely like that of the underlying bedrock, consisting of sedimentary rocks alternating with andesitic lavas and tuffs, but at the igneous contact, perknitic rocks appear, followed upstream by other ultrabasic gravels. The average thickness of the overburden in the pay streak of Squirrel Creek is about 13 feet; in the most westerly mining cut near Tupper Gulch, a small tributary from the west that joins Squirrel Creek close to the junction of claims $1 \mathrm{~B}$ and $2 \mathrm{~B}$ (below Discovery), the thickness is about 20 feet.

The pay streak of Squirrel Creek has been worked for a distance of 3,900 feet, from the bend of the creek southward to Platinum Creek. About 2,600 feet was worked by small-scale mining methods; the entire pay streak was later reworked by a dragline excavator. In the first span of 2,600 feet, the pay streak ranged in width from 150 to 500 feet, being narrowest in the medial part of claim $3 \mathrm{~B}$ and widest in the vicinity of Tupper Gulch. Originally the pay streak was worked in as many as four parallel cuts; the most westerly cut, near Tupper Gulch, was of lowest grade. Some of the placer deposits of Squirrel Creek were of high grade, approaching 0.1 ounce of platinum metals per cubic yard; the average tenor for the whole pay streak is reported to have been about 0.03 ounce to the cubic yard.

The platinum metals recovered from the valley of Squirrel Creek were generally of coarser grain than those on Platinum Creek. The largest nugget known to have been found in this pay streak weighed 1.5 troy ounces ( 46.7 grams). The record of the composition of these metals is fairly complete but unfortunately is not such that the changes in composition may be traced sequentially downstream. Twenty-two analyses have been made of these platinum metals, presented in table 16.

The product of Squirrel Creek differs from that of Fox Gulch and upper Platinum Creek mainly in the content of iridium, the mean tenors being, respectively, 15.76 and 28.11 percent. This suggests that the platinum lodes at the head of Squirrel Creek were lower in osmiridium than those at the head of Fox Gulch. A similarity is that the highest tenors in iridium, osmium, and ruthenium were found in the upper part of the pay streak, diminishing downstream. A possible explana-

TABLE 16.-Analyses, in percent, of precious metals, Squirrel Creek

\begin{tabular}{|c|c|c|c|c|c|c|c|}
\hline & $\mathrm{Pt}$ & Ir & $\mathrm{Os}$ & $\mathrm{Ru}$ & $\mathbf{R h}$ & $\mathbf{P d}$ & $\mathrm{Au}$ \\
\hline $\begin{array}{l}\text { A } \\
\text { B } \\
\text { C } \\
\text { D }\end{array}$ & \begin{tabular}{c|} 
\\
\hdashline
\end{tabular} & $\begin{array}{r}15.68 \\
15.76 \\
19.31 \\
7.14\end{array}$ & $\begin{array}{l}3.92 \\
3.95 \\
4.45 \\
1.21\end{array}$ & $\begin{array}{l}0.72 \\
.72 \\
.39 \\
.10\end{array}$ & $\begin{array}{l}1.58 \\
1.59 \\
1.89 \\
1.38\end{array}$ & $\begin{array}{l}0.34 \\
.34 \\
.36 \\
.51\end{array}$ & $\begin{array}{l}0.55 \\
--- \\
--- \\
-1 .-\end{array}$ \\
\hline
\end{tabular}

A. Mean value of 22 analyses, recomputed free of impurities.

B. Same as A, recomputed free of gold and impurities.

C. Analysis of product from upper end of pays treak showing minimum content of platinum and maximum contents of iridium and osmium, recomputed free of gold and impurities. D. Analysis of product from lower end of pay streak showing maximum content of platinum and minimum contents of iridium and osmium, recomputed free of gold and impurities. tion of this anomaly is that the upper horizons in the lodes may have had lower tenors in osmiridium, and as these were first eroded, they were washed farther downstream.

The tenors in gold on Squirrel Creek, like those of the platinum metals, cannot be arranged sequentially downstream. They appear, however, to show a considerable variation, as the minimum and maximum values are 0.12 and 1.40 percent; the mean value is 0.55 percent, about 50 percent greater than that on Fox Gulch and the upper Platinum Creek. As elsewhere in this district, gold is an alien mineral introduced by glaciation and is therefore unrelated to the distribution of the platinum metals.

\section{Lower Platinum Creek}

Two pay streaks were present on Platinum Creek for a short distance below the mouth of Squirrel Creek. One on the north side of the valley was the continuation of the pay streak of Squirrel Creek and the other was the downstream extension of the pay streak of upper Platinum Creek. The former was mined as far as it persisted, but the main pay streak appeared to be on the south side of the valley. The main pay streak at the mouth of Squirrel Creek had a width of about 120 feet but widened downstream, attaining a width of 400 feet at the confluence with the Salmon River.

The placers in the lower valley of Platinum Creek were not mined sequentially; it is therefore not possible to arrange the available analyses downstream or even to state the sites of the cleanups that showed the largest and smallest tenors in platinum, or reciprocally the smallest and largest tenors in iridium, osmium, and ruthenium. As might be expected, some of the richest deposits were found at or just below the mouth of Squirrel Creek, where the pay streak of upper Platinum Creek joined that of Squirrel Creek.

The platinum metals of lower Platinum Creek clearly were derived from two different types of lodes; it is therefore of interest to examine the metals downstream from the mouth of Squirrel Creek. In relation to the tenors of the platinum metals in the valley of the Salmon River, a general mean of the metals in the entire valley of Platinum Creek proves to be significant. The analyses of precious metals in the lower valley of Platinum Creek, and in the entire valley of Platinum Creek and its tributaries, are shown in table 17.

The mean values of the platinum metals from the lower valley of Platinum Creek, when compared with the mean values from the two headwater tributaries, are highly significant. Such a comparison shows that the platinum metals in the lower valley of Platinum Creek are more closely related to the product of Squirrel Creek than to that derived from Fox Gulch and the 
TABLE 17.-Analyses, in percent, of precious metals, valley of Platinum Creek

\begin{tabular}{|c|c|c|c|c|c|c|c|}
\hline & $\mathrm{Pt}$ & I $\mathbf{r}$ & Os & $\mathbf{R u}$ & $\mathrm{Rh}$ & $\mathbf{P d}$ & $\mathrm{Au}$ \\
\hline $\begin{array}{l}\mathrm{A} \\
\mathrm{B} \\
\mathrm{C} \\
\mathrm{D} \\
\mathrm{E} \\
\mathrm{F}\end{array}$ & $\begin{array}{r}77.03 \\
-\quad 77.45 \\
-\quad 68.73 \\
-\quad 82.02 \\
-73.05 \\
-73.41\end{array}$ & $\begin{array}{l}16.76 \\
16.85 \\
23.77 \\
13.04 \\
19.88 \\
19.98\end{array}$ & $\begin{array}{l}3.62 \\
3.64 \\
5.10 \\
2.90 \\
4.23 \\
4.25\end{array}$ & $\begin{array}{r}0.27 \\
.27 \\
.43 \\
.20 \\
.45 \\
.45\end{array}$ & $\begin{array}{l}1.44 \\
1.45 \\
1.65 \\
1.52 \\
1.59 \\
1.60\end{array}$ & $\begin{array}{r}0.34 \\
.34 \\
.32 \\
.32 \\
.31 \\
.31\end{array}$ & $\begin{array}{c}0.54 \\
--- \\
--- \\
-49 \\
---\end{array}$ \\
\hline
\end{tabular}

Mean value of 38 analyses of the products from the mouth of Squirrel Creek to the confluence with the Salmon River, recomputed free of impurities. Same as A, recomputed free of gold and impurities.

Analysis showing minimum content of platinum and maximum contents of iridium, osmium, and ruthenium, recomputed free of gold and impurities.

Analysis showing maximum content of platinum and minimum contents of iridium,

asmium, and ruthenium, recomputed free of gold and impurities Same as E, recomputed free of gold and impurities.

upper valley of Platinum Creek. Without the actual weights of the cleanups, no quantitative apportionment can be given, but the tabulated percentages suggest that as much as 80 percent of the platinum metals in the lower valley of Platinum Creek may have issued from the valley of Squirrel Creek. This suggests that bedrock lodes are more likely to be discovered at the head of Squirrel Creek than at the head of Fox Gulch. Any statement concerning platinum lodes of commercial value, however, must be qualified by two conditions: first, the original lodes may or may not have been entirely eroded and, second, any remaining lodes may be either of high or low grade. Only exploratory drilling will resolve these alternatives.

The content of gold in the lower valley of Platinum Creek is approximately the same as in the valley of Squirrel Creek. This similarity supports the inference that most of the precious metals entered the lower valley of Platinum Creek from Squirrel Creek rather than from Fox Gulch and the upper valley of Platinum Creek. It should be emphasized that all the gold in the valley of Platinum Creek was derived from the morainal material left by the older (Nebraskan) glacier with no additional increments from outwash deposits of Kansan or Illinoian age. This constitutes a fundamental difference between the valley of Platinum Creek and the valley of the Salmon River.

\section{Last Chance, Boulder, and Dowry Creeks}

Several gulches northeast of Squirrel Creek are tributary to the Salmon River, which named from south to north are Last Chance, Boulder, Dowry, and Clara Creeks. Platinum metals occur on Last Chance Creek, but no workable ground has been found; mining has been done on Boulder and Dowry Creeks. No data are available on the widths and depths of the pay streaks on these two streams or on the nature of the alluvial cover. One analysis has been made of the platinum metals recovered from Boulder Creek, and five analyses have been made of the product of Dowry Creek. The mean values of these analyses are presented in table 18.

The platinum metals of Boulder Creek are similar to those of Squirrel Creek, whereas the metals of Dowry Creek closely approach those of Clara Creek. The decrease northward in iridium, osmium, and ruthenium and the corresponding increase in platinum are notable features of this product. The tenor of gold from Boulder Creek is the same as the mean tenor from Squirrel Creek, but the mean value of gold from Dowry Creek is much greater, veering toward the still larger values on Clara Creek.

TABLE 18.-Analyses, in percent, of precious metals, Boulder and Dowry Creeks

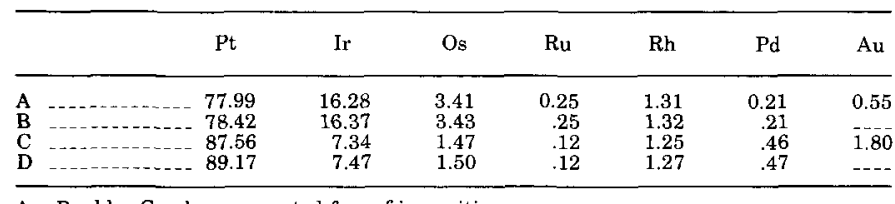

A. Boulder Creek, recomputed free of impurities.

B. Same as A, recomputed free of gold and impurities.

D. Dowry Creek, mean of five analyses, recomputed free of impurities.

D. Same as C, recomputed free of gold and impurities.

Clara Creek

Clara Creek, about 2 miles long, enters the Salmon River from the west about $3 \% / 4$ air miles upstream from the mouth of Platinum Creek. The valley is not well marked; its headwaters and its watershed consist of a straight shallow gulch without tributaries, incised in the northeastern side of Red Mountain. The total area of the watershed is estimated to be about $1 \frac{11}{2}$ square miles.

Seven placer claims have been staked on Clara Creek. The actual extent of the mining done by the early operators and by the Clara Creek Mining Co. is not known; the company mined on Discovery claim and on claims $1 \mathrm{~A}, 2 \mathrm{~A}$, and $3 \mathrm{~A}$, defining a pay streak with a length of at least 1 mile. The overburden on Clara Creek is 10-12 feet deep; the upper 2 or 3 feet consists of turf, peat, and dark-colored mossy material mixed with sand. The underlying gravel is subangular and of small size, averaging perhaps 3-4 inches in diameter, though some large cobbles are present. The gravel consists both of rocks of local origin and other material derived from glaciofluvial deposits on the divide between the Salmon and the Smalls Rivers. Along the north side of the pay streak at the west end of claim $3 \mathrm{~A}$, mining operations uncovered large boulders as much as 3 or 4 feet in diameter in the upper horizons of the gravels. These boulders are interpreted as glacial erratics that were deposited at higher altitudes on the northeast slope of Red Mountain and migrated slowly downhill into the valley of Clara Creek. As the extent of the older glaciation is indeterminate, such boulders are considered to be a part of the Illinoian outwash deposits. 
Bedrock exposed by mining in 1937 consisted of metamorphosed rocks of several types that included sheared chert, quartzites derived from chert and graywacke, tuffaceous rocks, and chloritic siliceous schist; some of these are greatly decomposed by weathering. The cleavage and schistosity of these rocks appear to be local phenomena induced by stresses incident to the intrusion of the ultrabasic massif of Red Mountain. Mining operations revealed a bedrock floor with an asymmetrical profile, rising steeply to the south and gradually to the north.

The pay streak of Clara Creek was worked in two operations, one on the north side of the stream, one on the south side. The total width is estimated to have been $200-250$ feet. The pay streak was found to extend from the contact between the ultrabasic rocks and the metamorphosed sedimentary rocks downstream almost to the Salmon River, but the records are vague. Early mining showed a tenor of as much as 0.08 ounce of platinum metals to the cubic yard, but the overall tenor, as determined by dragline mining, was closer to 0.02 ounce per cubic yard.

The platinum metals on Clara Creek are rather fine grained, although nuggets have been recovered, the largest 2 troy ounces (62.2 grams). Most of the precious metals were found in the gravels close to bedrock, but at some places 3-4 feet of fractured bedrock had to be excavated in order to obtain a high recovery. It was found unwise to strip off more than 2-3 feet of the overburden, as the upper horizons of gravel were in some degree platiniferous.

Six analyses are available of the platinum metals recovered from the placers of Clara Creek. Three of these were made by Matthey-Bishop, Inc., one by D. C. Griffith \& Co., one by the Wildberg Bros. Smelting and Refining Co., and one by K. J. Murata of the U.S. Geological Survey. The results of this analytical work are not altogether consistent, but the mean values, as shown in table 19 , are believed to represent closely the true proportions of the precious metals.

The mean content of gold is greater for Clara Creek than for any of the other western headwater tributaries of Platinum Creek; in fact, it is of the same order of magnitude as the mean content for the pay streak of the valley floor of the Salmon River. From this, it is inferred that a considerable volume of outwash deposits,

TABLE 19-Mean analyses, in percent, of precious metals, Clara Creek

\begin{tabular}{|c|c|c|c|c|c|c|c|}
\hline & $\mathrm{Pt}$ & I $\mathbf{r}$ & Os & $\mathrm{Ru}$ & $\mathrm{Rh}$ & $\mathrm{Pd}$ & $\mathrm{Au}$ \\
\hline B & $\begin{array}{l}88.61 \\
91.23\end{array}$ & $\begin{array}{l}6.05 \\
6.23\end{array}$ & $\begin{array}{l}0.97 \\
1.00\end{array}$ & $\begin{array}{r}0.09 \\
.09\end{array}$ & $\begin{array}{l}1.01 \\
1.04\end{array}$ & $\begin{array}{r}0.40 \\
.41\end{array}$ & $\begin{array}{l}2.87 \\
---\end{array}$ \\
\hline
\end{tabular}

A. Mean values of six analyses, recomputed free of impurities.

B. Mean values of six analyses, recomputed free of gold and impurities. deposited originally at the head of the Salmon River, was reworked to yield this increment in gold.

$$
\text { McCann Creek }
$$

A small stream known as McCann Creek heads against Clara Creek and flows northward to the Smalls River. Its valley contains some platinum metals but has not yielded a workable pay streak. No complete analyses are available, but John Cochrane analyzed eight hand-picked grains and found that on treatment with aqua regia the soluble part contained 95.5 percent platinum, 2.8 percent iridium, 1.2 percent rhodium, and 0.5 percent palladium. These figures are very close to the mean values shown as the composition of the principal alloy in table 7 . The ratio $K=S / I$ was found to be 7.42, which is a little larger than the mean value of 5.34 in table 7 , but of the same order of magnitude. No analysis was made of the insoluble fraction. It therefore appears that the platinum metals of McCann Creek are comparable with those at the head of the bench pay streak, which correlate with the metals of Clara Creek.

A comparison of the platinum metals from the streams that drain the eastern slope of the Red Mountain ridge is shown by the mean analyses from six areas, named from south to north (table 20). These values are charted and analyzed in the discussion of platinum lodes.

\section{SALMON RIVER}

Most of the platinum metals of the Goodnews Bay district have been recovered from two pay streaks in the valley of the Salmon River, although this stream does not erode any area of platiniferous rocks. One of these pay streaks is in the present valley floor; the other, called the bench pay streak, occupies a depression along the east wall of the valley. Most of these platinum metals have been derived from the western headwater tributaries of the Salmon River; a small part has come from the eluvial deposits along the eastern and southern flanks of the Red Mountain ridge. The volumes of platinum metals so far recovered from these two pay

TABLE 20-Comparison of platinum metals, in percent, from streams on east flank of Red Mountain ridge

\begin{tabular}{|c|c|c|c|c|c|c|}
\hline & $\mathrm{Pt}$ & $\mathrm{Ir}$ & Os & $\mathrm{Ru}$ & $\mathrm{Rh}$ & $\mathrm{Pd}$ \\
\hline A & 63.94 & 28.11 & 5.41 & 0.48 & 1.83 & 0.23 \\
\hline B & 77.64 & 15.76 & 3.95 & $\begin{array}{l}.70 \\
.72\end{array}$ & 1.59 & .34 \\
\hline $\mathrm{C}$ & 77.45 & 16.85 & 3.64 & .27 & 1.45 & 34 \\
\hline D & 78.42 & $\begin{array}{l}16.37 \\
10.37\end{array}$ & $\begin{array}{l}0.04 \\
3.43\end{array}$ & .25 & $\begin{array}{l}1.40 \\
1.32\end{array}$ & .21 \\
\hline $\mathbf{E}$ & 89.17 & 7.47 & $\begin{array}{l}0.40 \\
1.50\end{array}$ & 12 & 1.27 & .47 \\
\hline $\mathbf{F}$ & 91.23 & 6.23 & 1.00 & .09 & 1.04 & .41 \\
\hline
\end{tabular}

A. Fox Gulch and the valley of Platinum Creek above the mouth of Squirrel Creek

A. Valley of Squirrel Creek.

B. Valley of Squirrel Creek.
D. Valley valley of Platinum Creek.
E

E. Valley of Dowry Creek.

Valley of Clara Creek. 
streaks, as gauged by mining data, are nearly equal, but as the southern end of the bench pay streak has not yet been worked, its total content of platinum metals must considerably exceed that of the pay streak of the valley floor. Moreover, the total volume of platinum metals recovered and recoverable from these two pay streaks is probably 10 times as great as that recovered from the headwater tributaries. And finally, these two pay streaks were deposited at widely different times. All these facts indicate a very long period of erosion and a considerable vertical range in the original platiniferous lodes of Red Mountain. Gold, which constitutes only about 2.4 percent of the output, is an alien metal derived from a moraine that once occupied the valley of the Salmon River and from glaciofluvial deposits that now form the divide between the head of the Salmon River and the Smalls River. These and other data to be presented point to a complex history of the placers, involving their accumulation throughout the Pleistocene epoch.

$$
\text { Pay Streak of the Valley Floor }
$$

The bedrock floor of the Salmon River is characterized by one or more $\mathrm{V}$-shaped incisions indicative of incomplete stream rejuvenation. Drilling has shown that the main incision begins at claim $8 \mathrm{~A}$ and deepens downstream, attaining a depth of 15 feet in the wide valley floor of Discovery claim. Above and below the mouth of Snow Gulch, there are two such incisions, showing a lateral migration of the rejuvenated stream. The main incision extends a short distance up the valleys of Platinum and Medicine Creeks. This configuration persists downstream and attains a depth of 50 feet on claim 15B. This incision was caused by a regional lowering of the base level of erosion which did not persist long enough for the river to carve a new and widened valley floor. There appears to be no additional concentration of platinum metals in this elongate trench. The chronology of the erosional features in relation to the gravels of the valley floor is uncertain; the absence of enrichment in precious metals suggests that the trench may have predated the deposition of the main gravel covering.

The bedrock of the valley floor consists of a mixture of unweathered sedimentary and igneous rocks. The sedimentary rocks include highly indurated graywacke, siliceous argillite, and chert, together with dikes and sills of intrusive rocks, mainly of andesitic character, and siliceous tuffs. Bedrock is exposed in the valley floor at only two places, both along the east wall. One such exposure is on claim 14B; the other is on a bench claim just east of claim 15B. These outcrops are actually surficial protuberances of the bedrock reef that separates the two pay streaks.
The pay streaks of the valley floor starts at the mouth of Clara Creek and continues without interruption downstream for an airline distance of about 6 miles, extending to the lower part of claim 15B. At the lower end of claim $6 \mathrm{~A}$ where dredging ended, the average diameter of the gravels is 6-8 inches, with some cobbles and occasional boulders as large as 2 feet in diameter. All these gravels are essentially unweathered and are nearly as firm as the underlying bedrock. Unlike the bench pay streak, clay is generally absent except on claim $4 \mathrm{~B}$ and for a few claim lengths downstream, where the two pay streaks are laterally contiguous and have bedrock floors at nearly the same altitude. The thickness of the gravels increases gradually downstream, ranging from 30 feet on claim 5A, to 75 feet at the lower end of claim 15B, exclusive of the bedrock trench. The precious metals may extend downward into bedrock for several feet; to insure a high recovery, the dredge excavated at least 3 feet of bedrock.

The width of the pay streak is variable. At the mouth of Clara Creek, the width is 250 feet; on the lower end of claim 6A, 300 feet; on Discovery claim, at the mouth of Platinum Creek, 1,000 feet; on claim 3B, 800 feet; on claim 6B, 400 feet; and on claim 15B, 600 feet. The overall gradient of bedrock over the distance mined is 41.2 feet to the mile, or 13.5 feet less than that of the bench pay streak. On the lower end of claim $6 \mathrm{~A}$ the altitude of bedrock is 50 feet lower than on the adjacent bench pay streak; at a point on the upper end of claim $7 \mathrm{~B}$, the bedrock of the two pay streaks, though separated from one another by a rock barrier, has the same altitude. A bedrock reef everywhere separates the channels of the two pay streaks, except on claim 4B, where for a short distance the two pay streaks are contiguous, although the altitude of the bench channel is 5 feet higher than the bedrock of the stream channel. Where the Salmon River discharges into Kuskokwim Bay, the bedrock of the main valley floor (not in the incision) is at least 100 feet below sea level. The complexity of the geomorphic history is indicated by the fact that the bedrock of the bench channel, projected to Chagvan Bay, is about 250 feet below sea level.

The pay streak of the valley floor has been dredged in two cuts from the lower end of claim $6 \mathrm{~A}$ to the lower end of claim 15B. A third cut from claim $10 \mathrm{~B}$ to claim $5 \mathrm{~B}$ was completed in 1972. Thereafter the dredge moved eastward onto the bench pay streak and began to mine marginal ground and to rework old tailings. The uppermost 5 claims in the valley floor from $6 \mathrm{~A}$ to $10 \mathrm{~A}$ have not yet been mined but will probably be worked by a large dragline excavator.

Dredging and dragline mining of the pay streak of the valley floor has yielded 404 cleanups through 1972 . The available record includes 308 sieve analyses for the 
periods 1938-39 and 1942-72; a record of the sieving analyses for the period $1940-41$ is lacking, although the production records are available. The mean granularity of the platinum metals for the stated intervals is shown by claims in table 21 . The sizes of the grains and the relative magnitudes of the production for each claim up to 1972 , with the elimination of ordinates, in order to conform with the practice of the U.S. Geological Survey not to reveal the production of individual properties, are charted in figure 10.

Curve 3 of figure 10, which illustrates the distribution of the smallest grains, clearly shows that the granularity diminishes progressively, though not linearly, downstream; the reverse is necessarily true for curves 1

TABLE 21.-Percentage of mean sizes (S) of platinum grains by claims, pay streak of valley floor, Salmon River

\begin{tabular}{|c|c|c|c|c|}
\hline Claim & $\begin{array}{c}\text { Number } \\
\text { of } \\
\text { analyses }\end{array}$ & $S>0.83 \mathrm{~mm}$ & $0.83 \mathrm{~mm}>S>0.42 \mathrm{~mm}$ & $0.42 \mathrm{~mm}>S$ \\
\hline $5 \mathrm{~A}$ & 10 & 21.89 & 41.69 & 36.42 \\
\hline $4 \mathrm{~A}$ & 14 & 20.31 & 41.11 & 38.58 \\
\hline $3 \mathrm{~A}$ & 13 & 18.41 & 43.52 & 38.07 \\
\hline $2 \mathrm{~A}$ & 13 & 24.23 & 42.25 & 33.52 \\
\hline $1 \mathrm{~A}$ & 18 & 27.52 & 36.65 & 35.83 \\
\hline D & 26 & 25.33 & 53.79 & 20.88 \\
\hline $1 \mathrm{~B}$ & 19 & 25.94 & 43.55 & 30.51 \\
\hline $2 \mathrm{~B}$ & 10 & 26.57 & 42.35 & 31.08 \\
\hline $3 \mathrm{~B}$ & 15 & 22.13 & 46.69 & 31.18 \\
\hline $4 \mathrm{~B}$ & 16 & 13.98 & 49.73 & 36.29 \\
\hline 5B & 12 & 16.19 & 31.91 & 51.90 \\
\hline $6 \mathrm{~B}-\ldots$ & 7 & 11.51 & 28.91 & 59.58 \\
\hline $8 B$ B & 19 & 7.23 & 26.40 & 66.37 \\
\hline $9 \mathrm{~B}$ & 21 & 5.61 & 24.31 & 70.08 \\
\hline $10 \mathrm{~B}$ & 22 & 7.41 & 24.03 & 68.56 \\
\hline $11 \mathrm{~B}$ & 16 & 3.82 & 13.43 & 82.75 \\
\hline $12 \mathrm{~B}$ & 16 & 3.99 & 15.60 & 80.41 \\
\hline $13 \mathrm{~B}$ & 15 & 5.43 & 16.04 & 78.53 \\
\hline $14 \mathrm{~B}$ & 16 & 3.34 & 14.12 & 82.54 \\
\hline 15B & 10 & 2.41 & 10.39 & 87.20 \\
\hline
\end{tabular}
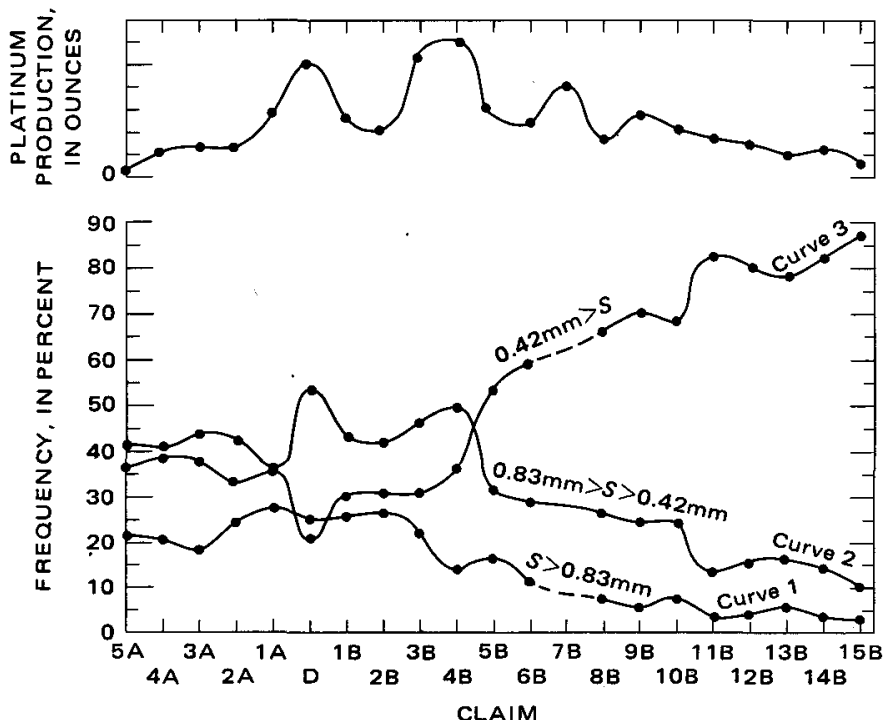

Figure 10.-Mean size (S) of platinum grains by claims (curves 1, 2, and 3) and production curve for pay streak of valley floor, Salmon River. D, Discovery claim; A, claim above Discovery; B, claim below Discovery. and 2. In fact, the percentage of grains larger than $0.83 \mathrm{~mm}$ diminishes nearly to zero on claim $15 \mathrm{~B}$. A diminution of grain size less than $0.42 \mathrm{~mm}$ shows in curve 3 on Discovery claim, and a corresponding increase in grain size is shown by curve 2 . This relation undoubtedly has resulted from the addition of a large volume of coarser metals from the valley of Platinum Creek.

Noticeable irregularities appear in the three granularity curves on claim $4 \mathrm{~B}$ and on claim $11 \mathrm{~B}$. From the upper end of the pay streak of the valley floor downstream to claim $7 \mathrm{~B}$, the bedrock of the valley floor is lower than that of the bench pay streak; the valley floor could have been enriched from the bench where tributary streams, such as Medicine Creek, Snow Gulch, and Anita Creek, entered from the east. Such enrichments could account for the irregularities on claim $4 \mathrm{~B}$, but the variations on claim 11B have resulted from another cause, probably that some enrichment has occurred from an ancient pay streak high on the east wall of the Salmon Valley that antedated the formation of the bench pay streak. An enrichment of this kind cannot be related to specific tributaries, as the courses of such streams must have changed greatly since the early development of the main valley.

The composition of the platinum metals in the pay streak of the valley floor is established by 404 analyses representing that number of shipments to the refiner. The $22 \mathrm{~d}$ or final listing shows the mean value of 9 additional analyses whose granularity was less than $0.15 \mathrm{~mm}$. These samples were anlayzed separately, and because they accumulated from one cleanup to another, they cannot be assigned to individual claims. The 404 analyse have been averaged claim by claim, starting at claim $5 \mathrm{~A}$ and extending downstream to claim $15 \mathrm{~B}$; the resulting values are presented in table 22 .

TABLE 22.-Percentage of mean values of platinum analyses by claims, pay streak of valley floor, Salmon River

\begin{tabular}{|c|c|c|c|c|c|c|c|}
\hline Claim & $\begin{array}{c}\text { Number } \\
\text { of } \\
\text { analyses }\end{array}$ & $\mathrm{Pt}$ & I $\mathbf{r}$ & Os & $\mathrm{Ru}$ & $\mathrm{Rh}$ & $\mathrm{Pd}$ \\
\hline $5 \mathrm{~A}$ & 8 & 90.20 & 6.82 & 1.25 & 0.08 & 1.20 & 0.45 \\
\hline $4 \mathrm{~A}$ & 9 & 90.43 & 6.67 & 1.19 & .08 & 1.18 & .45 \\
\hline $3 \mathrm{~A}$ & 9 & 90.49 & 6.61 & 1.18 & .08 & 1.19 & .45 \\
\hline $2 \mathrm{~A}$ & 11 & 89.48 & 7.37 & 1.35 & .09 & 1.24 & .47 \\
\hline $1 \mathrm{~A}$ & 25 & 86.81 & 9.53 & 1.82 & .13 & 1.28 & .43 \\
\hline D & 48 & 84.31 & 11.65 & 2.32 & .18 & 1.18 & .36 \\
\hline 1B & 29 & 83.84 & 11.78 & 2.39 & .19 & 1.43 & .37 \\
\hline $2 \mathrm{~B}$ & 25 & 83.74 & 11.92 & 2.39 & .19 & 1.37 & .39 \\
\hline 3B $\ldots$ & 34 & 83.91 & 11.86 & 2.37 & .17 & 1.30 & .39 \\
\hline $4 \mathrm{~B}$ & 39 & 82.62 & 12.94 & 2.48 & .19 & 1.38 & .39 \\
\hline $5 \mathrm{~B}$ & 26 & 82.12 & 13.25 & 2.65 & .20 & 1.40 & .38 \\
\hline 6B & 25 & 81.84 & 13.53 & 2.68 & .22 & 1.37 & .36 \\
\hline $7 \mathrm{~B}$ & 25 & 81.16 & 13.83 & 2.89 & .24 & 1.47 & .41 \\
\hline $8 \mathrm{~B}$ & 15 & 81.32 & 13.96 & 2.94 & .23 & 1.20 & .35 \\
\hline $9 \mathrm{~B}$ & 13 & 80.56 & 14.62 & 2.99 & .24 & 1.24 & .35 \\
\hline $10 \mathrm{~B} \ldots \ldots$ & 15 & 80.63 & 14.62 & 2.86 & .23 & 1.31 & .35 \\
\hline $11 \mathrm{~B}$ & 13 & 79.67 & 15.32 & 3.04 & .24 & 1.35 & .38 \\
\hline 12B & 11 & 77.47 & 15.35 & 3.22 & .24 & 1.37 & .35 \\
\hline 13B & 9 & 79.90 & 15.18 & 3.13 & .24 & 1.18 & .37 \\
\hline $14 \mathrm{~B}$ & 8 & 79.53 & 15.37 & 3.25 & .24 & 1.27 & .34 \\
\hline 15B & 7 & 79.26 & 15.57 & 3.34 & .24 & 1.26 & .33 \\
\hline-100 fines & 9 & 72.18 & 20.88 & 4.79 & .33 & 1.41 & .41 \\
\hline Weighted means & & 83.07 & 12.52 & 2.51 & .19 & 1.32 & .39 \\
\hline
\end{tabular}


Two sources of error arise in this compilation. All mining in the valley floor has been done by dredging, but all cleanups did not have the same weights; moreoever, a part of one cleanup was added occasionally to the next. But the analyses are sequential, and as the composition varies little from one cleanup to the next, this discrepancy is largely cancelled by the mean analyses.

A more significant source of error arises from the fact that percentages cannot be averaged, arithmetically or otherwise, except by weighting. The percentages in the analyses cannot be weighted. The weights of the shipments vary considerably and are not known to the writer, though ordinarily they are of the same order of magnitude, ranging from 300 to 400 troy ources. However, the composition of the platinum metals differs little from one cleanup to the next and does not differ greatly from the terminal part of one claim to the initial part of the next. For these reasons, it is believed that the arithmetical means of the analyses are not greatly in error as representative of consecutive claims.

The mean analyses of the platinum metals for the valley floor and for the bench pay streak are charted in figure 11. This is feasible as there is no interference between the two sets of curves. Three curves are charted for each pay streak: one for platinum, one for iridium, and one for osmium plus ruthenium, the two hexagonal elements. The curves for rhodium and palladium are

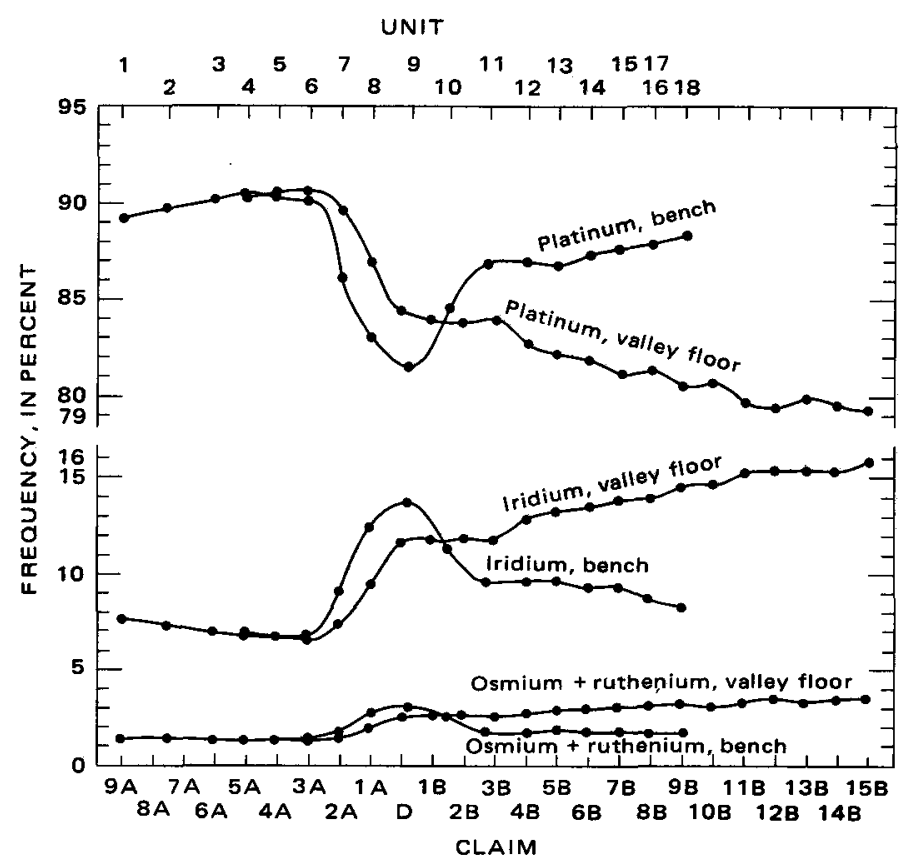

FrGURE 11.-Mean analyses of four platinum metals by claims and units, pay streaks of valley floor and bench, Salmon River. D, Discovery claim; A, Claim above Discovery; B, Claim below Discovery. omitted, as these two scarce elements have little significance. The outstanding feature of these curves is the reciprocal relation between the curves for platinum and those that represent iridium and osmium plus ruthenium, a reflection of the dominance of platinum in the principal alloy and the prevalence of iridium, osmium, and ruthenium in the osmiridium. The magnitude of platinum compared with the other metals indicates the dominance of the principal alloy in the placer product. This feature is corroborated by the examination of polished sections of nuggets and grains under the microscope, where the areas of osmiridium are seen to be smaller and less common than those of the principal alloy.

Examination of the curves of the pay streak of the valley floor shows that at claim 3A platinum shows a sharp decrease downstream to Discovery claim, and the decline continues more slowly downstream to claim 15B. Conversely, the amount of iridium suddenly begins to increase at claim $3 \mathrm{~A}$ and continues to increase to Discovery claim, where the variation curve changes to a slow but progressive increase that continues downstream to claim 15B. The curve of osmium plus ruthenium with flattened flexures behaves concordantly with the curve of iridium, suggesting that most of the iridium is contained in osmiridium.

Several factors enter into the distribution of the platinum metals in the pay streak of the valley floor. First, the metals above the mouth of Platinum Creek are notably different from those entering the Salmon Valley from Platinum Creek in that the Ir:Pt ratio in those above the mouth is lower. Moreover, fewer platinum metals originated in the valley of Salmon River above the mouth of Platinum Creek. As a result, the Ir:Pt ratio was appreciably raised by the metals from Platinum Creek. A second factor is the tendency of the coarser heavy metals not to migrate far downstream from their original sites of deposition unless rejuvenation or some other activating erosional process has taken place. The V-shaped incision in the valley floor of the Salmon River indicates an incipient rejuvenation which, however, never became effective in the upper valley. Hence the decrement of the Ir:Pt ratio that resulted from the addition of metals from the upper valley was relatively slight and was gradually overcome by the higher Ir:Pt ratio of the metals that issued from the mouth of Platinum Creek. The Ir:Pt ratio, 0.134 on Discovery claim, gradually increased to 0.196 on claim 15B, approaching the limiting value of 0.218 for the lower valley of Platinum Creek. A third factor may have been a "chulitna" or backhand drainage in the lower valley of Platinum Creek inherited from an earlier physiographic cycle, as later described, when the northern end of the bench channel drained toward the 
Smalls River. This would explain why the marked change in the composition of the platinum metals began on claim 3A instead of on Discovery claim.

Bench Pay Streak

The bench pay streak begins on the lower end of a left-limit bench claim opposite claim $10 \mathrm{~A}$ and has been worked downstream to the upper end of the Olson bench claim, opposite claim 10B, an air distance of 4.4 miles. The ancient channel occupied by this pay streak continues downstream to, or nearly to, Chagvan Bay, an additional $4^{1 / 4}$ miles. Drilling shows that this channel, about 1 mile from Chagvan Bay, splits into two distributary channels. The downstream limit of a commercial pay streak has not yet been firmly established, but intensive drilling had proven by 1969 that it extended as far south as Happy Creek. As this area is south of the Alaskan zone of permafrost, nearly all the overburden is unfrozen; drilling in the lower end of the bench pay streak, however, has revealed a number of frozen strata, some as thick as 20 feet.

The bedrock gradient of the bench channel over the distance mined is 54.7 feet per mile, or 13.5 feet greater than the gradient of bedrock on the valley floor of the Salmon River. At its upper end, the bedrock floor of the bench pay streak is about 80 feet higher than the corresponding bedrock of the valley floor. On claim 4B, where the two pay streaks are contiguous for a short distance, the bedrock of the bench channel is only 5 feet higher than that of the valley floor; opposite claim 7B, about 3,000 feet below the mouth of Anita Creek, the two channels have the same altitude, though separated by a bedrock reef. About 4.8 miles from Chagvan Bay, the bedrock of the bench channel is at sea level; and at Happy Creek, drilling has shown that the bedrock of the bench channel is 50 feet below sea level. At a point seven-eighths of a mile from Chagvan Bay, the bedrock lies 200 feet below sea level.

Still farther southwest, near the northern limit of the peninsula between Kuskokwim and Chagvan Bays, eight holes were drilled by the Goodnews Bay Mining Co. within an area of about 1 square mile. The depths of seven of these holes ranged from 68 to 110 feet; the eighth, located at lat. $58^{\circ} 48^{\prime} 27^{\prime \prime} \mathrm{N}$. and long. $161^{\circ} 44^{\prime} 24^{\prime \prime}$ W., was drilled to a depth of $2521 / 2$ feet and reached bedrock at 244 feet. Although these holes are in line with the bench pay streak, no platinum metals were found. The depth to bedrock is an index of the oceanic level during one of the glaciations even though it does not necessarily correlate with the formation of the bench pay streak; nor is the minimum depth of -244 feet indicative of the minimum base level of erosion in this area during the Pleistocene Epoch.

The thickness of the alluvium that overlies bedrock on the bench pay streak increases downstream from a thickness of only 10 feet at the northern limit of the pay streak to 45 feet east of Discovery claim and to 125 feet at the lower end of the Olson bench claim. With these thicknesses of overburden, it was possible to mine the upper end of the pay streak with a dragline excavator; from Medicine Creek downstream, all mining except some marginal strips was done by dredging. Unlike the operation on the valley floor, the mining of the bench pay streak was accomplished by a single, but very sinuous, traverse of the dredge moving both laterally and longitudinally.

The width of the bench pay streak was found to be variable, increasing generally but not linearly downstream. Opposite the mouth of Dowry Creek, the width of the pay streak was 200 feet; opposite Discovery claim, it widened to as much as 1,200 feet; on the Olson bench claim, it was 550 feet; and by drilling it has been established on the Alice Association claim to be between 750 and 800 feet. A characteristic feature of the bench pay streak is that the bedrock floor is nearly flat from side to side. This indicates a fairly constant base level of erosion for a long period of time, enabling the ancient stream that occupied this channel to carve away the lateral spurs, expanding the valley floor to its present shape and width.

The alluvium of the bench pay streak is about 80 percent clay and 20 percent gravel, reworked from the ancient moraine that occupied this channel. The gravel is erratically distributed vertically and occurs as lenticular beds inlaid in clay, generally ranging in thickness from 6 inches to 3 feet. Locally, particularly at the lower end of the pay streak, thick beds of gravel have been uncovered or located by drilling. On the lower end of the Olson bench claim in a drill hole 122 feet deep, gravel formed the upper 30 feet of the section, and on the Hannah bench claim, in a drill hole 135 feet deep, gravel constituted the upper 72 feet of the section; these superficial gravels are not platinum bearing. The gravels of the beds intercalated with the clay are typically subrounded to subangular, ranging generally in size between 2 and 3 inches in diameter, although some cobbles are present; the nonsiliceous types are greatly altered by weathering. Many of the gravels are so fractured and broken that sharp edges show along the faces of the siliceous types.

The precious metals are recovered from the lower 6-8 feet of clay and gravel and from the upper 3-4 feet of altered bedrock. The country rock is generally fractured, and the nonsiliceous varieties are so greatly altered that it is difficult in drilling at some localities to identify bedrock when it is reached, as it has disintegrated to mud. Bedrock is characterized by fractured grains of quartz and chert, and in order to obtain a 
complete recovery of the precious metals, drilling and mining are extended downward for about 7 feet into what is regarded as bedrock. It seems probable that the infiltration of the platinum metals into bedrock occurred at an early stage in the erosional history of the area, possibly beginning during the Pliocene Epoch and that the deep alteration of bedrock was a feature of much later date. Otherwise the bedrock, altered to clay, would have acted as a false bedrock, preventing the ingress of the platinum metals.

A feature of special interest is the incipient lithification of the clay in the overburden. Induration has progressed so far that the clay does not disintegrate entirely in the trommel screen of the dredge and this has caused appreciable losses of the precious metals. The magnitude of such losses was gauged in 1966 by the use of an experimental rig called a "mud hog," built and operated on the bench pay streak at a site opposite claim $4 \mathrm{~B}$ to rework the bench tailings. To obtain a complete recovery of the precious metals, it was necessary to pulverize not only the clay but also the intermixed and adhering gravels before sluicing, as the two were inseparable. This was an expensive operation, designed solely to appraise the losses incurred in dredging; yet this crude pilot plant showed a profit for the duration of the operation. A part of this indurated clay has evidently slaked under weathering, as the dredge is now successfully reworking the tailings on the Fourth of July bench and adjacent ground.

Exploratory drilling of the bench pay streak has now progressed into that part of the valley south of Happy Creek where a change has been observed in the character of the overburden. Clay and gravels of the type described still constitute the lower section of the alluvium, but at some sites the upper part consists of thick beds of cleaned, little weathered gravels similar to those in the bluffs along the lower Salmon River and those facing Kuskokwim Bay; in one line of drill holes south of Happy Creek, such gravels constitute the upper 115 feet of the section. It is evident that these are outwash gravels derived from an old Kinegnak glacier of Illinoian age that overrode the spur east of Happy Creek and followed a westerly course to the sea. That this glacier did not erode and obliterate the bench pay streak as it did the pay streak of the valley floor is doubtless due to the much greater depth of the older pay streak.

The granularity of the platinum metals on the bench pay streak is established by 402 sieve analyses from the same number of cleanups for the period 1942-69. The mean values of these analyses arranged by units that correspond roughly to the position of the creek claims are shown in table 23 and are charted in figure 12. The granularity curves of the platinum metals in the pay
TABLE 23.-Percentage of sizes (S) of platinum grains by units, bench pay streak, Salmon River

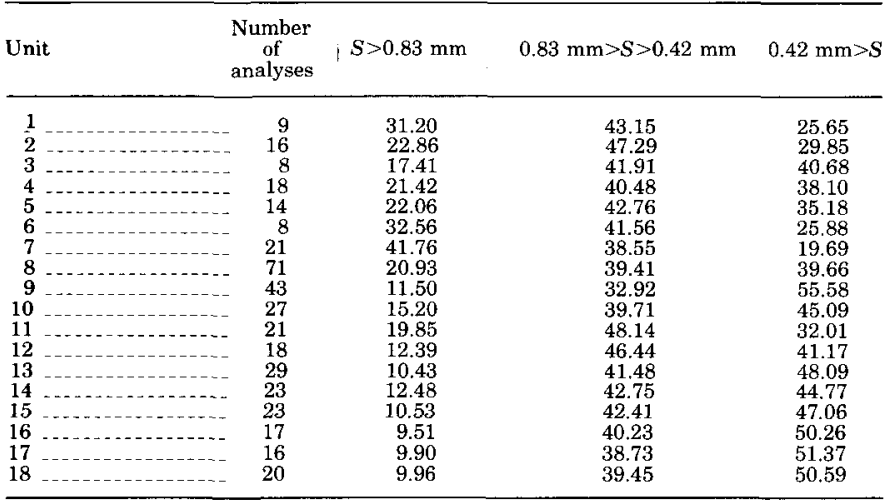
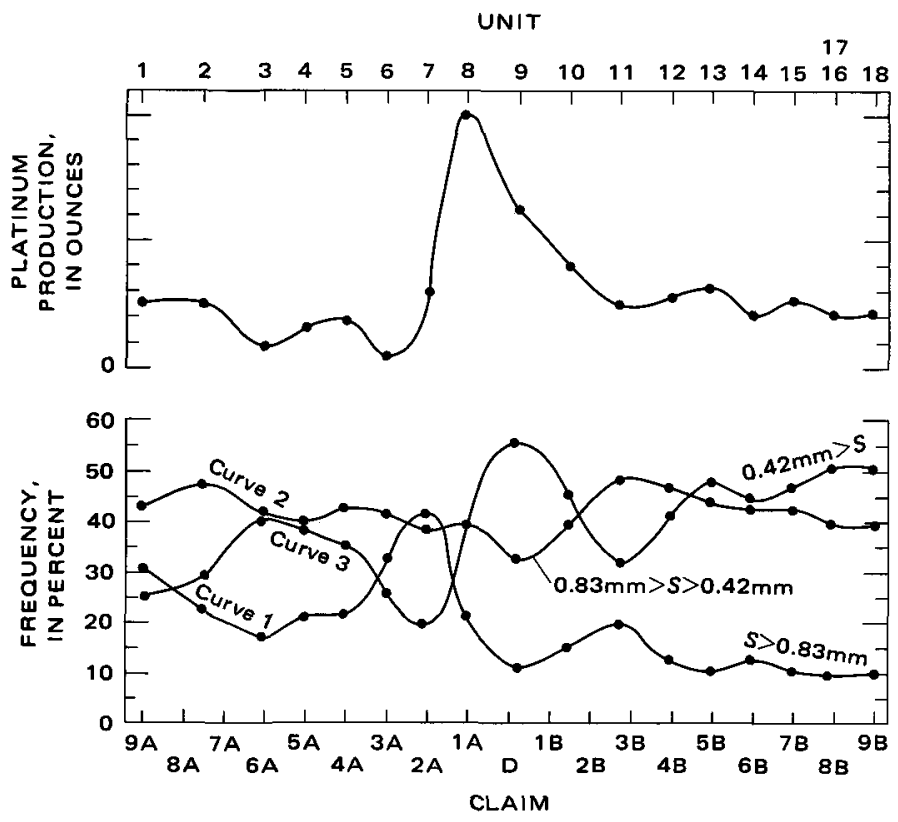

FIGURE 12.-Mean size $(S)$ of platinum grains by units (curves 1, 2, and 3) and production curve for bench pay streak, Salmon River. D, Discovery claim; A, Claim above Discovery; B, Claim below Discovery.

streak are complicated by the fact that the upper course of the ancient channel was northward to the Smalls River and later, by stream capture, was diverted southward. This led to a complex distribution of the precious metals that is evident in both the sieve analyses and the chemical analyses.

Curve 1 of the coarsest grains shows a maximum, and curve 3 of the finest grains a minimum in the zone of unit 7 , corresponding to claim $2 \mathrm{~A}$. This relation leads to two inferences: first, that relatively coarser metals issued from the valley of Platinum Creek than from farther upstream and, second, that during the early development of the bench pay streak, the course of the 
lower stretch of Platinum Creek was northeastward to a stream that drained into the Smalls River. Otherwise, the cited maximum and minimum would have shown opposite the mouth of Platinum Creek as they do in the pay streak of the valley floor. Curves 2 and 3 show a reverse relation at unit 9 opposite Discovery claim; a possible explanation is that this part of the curve represents a development subsequent to the stream piracy described. Finally, at unit 11, opposite claim $3 B$, another maximum for curve 1 and a minimum for curve 3 reappear. These flexures are believed to be the result of enrichment of the bench pay streak from an older channel high on the eastern valley wall, now represented by fragmentary remnants of alluvial deposits that are not commercially workable.

The mean granularity of the platinum metals in the two pay streaks is shown by the means of eight sieved fractions that represent the entire production from both pay streaks through 1969. No seiving records are available for the years prior to 1938 , and none are available for the years $1940-41$, but the record is otherwise complete, covering 710 cleanups. Thirtythree sieving records from the lower valley of Platinum Creek have been added to those of the valley floor of the Salmon River, making a total of 743 samples. These mean values are tabulated in table 24 .

Although it is not always possible to assign all cleanups to specified claims, the sums are known from the actual weights of the sieved fractions; the totals are therefore actually weighted mean values, which should have a high degree of dependability.

The mean granularities of the platinum metals in the bench pay streak and in the pay streak of the valley floor are respectively 0.528 and 0.553 , (table 24 ). The mean granularity of the metals from the bench is 4.5 percent less than that of the metals from the valley floor. This seems to be a small difference, but considering the volume of the available data, it is highly significant. Moreover, there is a striking difference in the size distribution of the platinum metals in the two pay streaks: The most plentiful metals recovered from the

TABLE 24.-Mean granularity of platinum metals in two pay streaks, valley of Salmon River

\begin{tabular}{|c|c|c|c|c|}
\hline Sieve sizes & $\begin{array}{l}\text { Mean sizes } \\
\quad(\mathrm{mm})\end{array}$ & $\begin{array}{l}\text { Valley floor } \\
\text { (percent) }\end{array}$ & $\begin{array}{c}\text { Bench } \\
\text { (percent) }\end{array}$ & $\begin{array}{c}\text { Entire out- } \\
\text { put } \\
\text { (percent) }\end{array}$ \\
\hline $\begin{array}{l}+12 \\
-12 \text { to }+14 \\
-14 \text { to }+20 \\
-20 \text { to }+28 \\
-28 \text { to }+35 \\
-35 \text { to }+48 \\
-48 \text { to }+100 \\
-100\end{array}$ & $\begin{array}{r}>1.40 \\
1.28 \\
1.00 \\
.71 \\
.50 \\
.36 \\
.22 \\
<.15\end{array}$ & $\begin{array}{rr}. & 3.35 \\
- & 3.57 \\
-- & 9.54 \\
-. & 13.64 \\
-.- & 11.62 \\
-. & 16.32 \\
- & 1.56\end{array}$ & $\begin{array}{r}3.77 \\
1.60 \\
9.25 \\
13.76 \\
20.31 \\
33.65 \\
16.08 \\
1.58\end{array}$ & $\begin{array}{r}3.57 \\
2.51 \\
9.39 \\
13.71 \\
25.58 \\
25.58 \\
18.12 \\
1.54\end{array}$ \\
\hline \multicolumn{2}{|l|}{ Total } & 100.00 & 100.00 & 100.00 \\
\hline \multicolumn{2}{|c|}{ Weighted mean size } & _. 0.553 & 0.528 & 0.539 \\
\hline
\end{tabular}

bench pay streak have a mean diameter of $0.36 \mathrm{~mm}$, whereas the mean diameter for the valley floor is $0.50 \mathrm{~mm}$. The most prevalent grains in the bench pay streak, in the range $0.42-0.30 \mathrm{~mm}$, are about twice as plentiful as the grains of the same size in the pay streak of the valley floor. This does not obtain for grains smaller than $0.30 \mathrm{~mm}$, as might be expected, because large amounts of fine-grained platinum metals were lost by retention in the semi-indurated clay of the bench pay streak.

The production curve for the bench pay streak (fig. 12) differs materially from that of the valley floor. There is a marked increment in the curve as a result of the high output from the valley of Platinum Creek, but the maximum point is at unit 8 opposite claim 1 above Discovery, rather than at Discovery claim. This increment, starting at unit 6 opposite claim $3 \mathrm{~A}$, is further evidence that the lower course of Platinum Creek was northeastward in the initial stage of the development of the bench channel. Two minor maxima are recognizable in the production curve of the bench pay streak at units 13 and 15. A possible explanation of these increments is enrichment from a more ancient platiniferous deposit high on the east wall of the valley, now represented only by eroded remnants.

The composition of the platinum metals in the bench pay streak is established by 412 superior analyses. These have been arranged by units, starting at unit 1, opposite claim 9A, and extending downstream to unit 18 opposite claim 10B, as shown in table 25. The final listing shows the mean value of 17 additional samples having a granularity smaller than $0.15 \mathrm{~mm}$ that cannot be referred to individual claims.

The composition of the platinum metals in the two pay streaks are charted in figure 11 . The bench curve of platinum metals shows a minimum value for platinum and a maximum value for iridium on unit 9 opposite

TABLE 25.-Percentage of mean values of platinum analyses by units, bench pay streak, Salmon River

\begin{tabular}{|c|c|c|c|c|c|c|c|}
\hline Unit & $\begin{array}{c}\text { Number } \\
\text { of } \\
\text { analyses }\end{array}$ & $\mathrm{Pt}$ & $\mathrm{Ir}$ & Os & Ru & $\mathrm{Rh}$ & $\mathrm{Pd}$ \\
\hline 1 & 26 & 89.16 & 7.65 & 1.35 & 0.09 & 1.30 & 0.45 \\
\hline 2 & 16 & 89.62 & 7.33 & 1.31 & .09 & 1.20 & .45 \\
\hline 3 & 7 & 90.14 & 6.96 & 1.19 & .08 & 1.16 & .47 \\
\hline 4 & 16 & 90.40 & 6.68 & 1.19 & .08 & 1.23 & .42 \\
\hline $5 \ldots$ & 17 & 90.20 & 6.75 & 1.27 & .09 & 1.29 & .40 \\
\hline 6 & 17 & 90.01 & 6.80 & 1.31 & .09 & 1.36 & .43 \\
\hline $7 \ldots$ & 20 & 87.23 & 9.09 & 1.73 & .13 & 1.39 & .43 \\
\hline $8-$ & 72 & 82.95 & 12.48 & 2.50 & .20 & 1.49 & .38 \\
\hline 9 & 45 & 81.51 & 13.66 & 2.86 & .21 & 1.40 & .36 \\
\hline $10^{-}$ & 32 & 84.45 & 11.32 & 2.25 & .18 & 1.40 & .40 \\
\hline $11 \ldots$ & 15 & 86.80 & 9.65 & 1.57 & .13 & 1.40 & .45 \\
\hline $12 \ldots \ldots$ & 15 & 86.87 & 9.63 & 1.63 & .13 & 1.32 & .42 \\
\hline $13 \ldots$ & 29 & 86.77 & 9.66 & 1.78 & .14 & 1.23 & .42 \\
\hline 14 & 23 & 87.31 & 9.33 & 1.66 & .13 & 1.20 & .37 \\
\hline $15 \ldots$ & 18 & 87.40 & 9.34 & 1.65 & .13 & 1.06 & .42 \\
\hline $16 \ldots$ & 17 & 87.92 & 8.76 & 1.56 & .13 & 1.20 & .43 \\
\hline 17 & 14 & 87.97 & 8.70 & 1.56 & .13 & 1.20 & .44 \\
\hline 18 & 13 & 88.21 & 8.56 & 1.57 & .13 & 1.12 & .41 \\
\hline-100 fines & 17 & 78.71 & 15.28 & 3.89 & .27 & 1.39 & .46 \\
\hline Weighted means & & -86.00 & 10.15 & 1.97 & .15 & 1.32 & .41 \\
\hline
\end{tabular}


Discovery claim, owing to the contribution of metals high in iridium from the valley of Platinum Creek, but these changes begin on unit 7 opposite claim $2 \mathrm{~A}$. The higher content of iridium upstream from unit 9 constitutes further proof that in an early stage in the development of the bench pay streak, the lower course of Platinum Creek was northeastward to a stream that discharged into the Smalls River.

The composition of the platinum metals shows diagnostic differences downstream from unit 9 as the tenor in platinum increases and that of iridium decreases. This is exactly the reverse of the relation that prevails in the pay streak of the valley floor. It is clear that there was an influx of high-iridium metals into both pay streaks from the valley of Platinum Creek at the same time that low-iridium metals were being added from the upper Salmon valley above the mouth of Platinum Creek. This anomaly can be explained by one of two factors, possibly by both: (1) The low-iridium metals of the upper valley may have migrated farther downstream, owing to the higher gradient of the bench channel, thus cancelling in some measure the output from Platinum Creek; (2) more low-iridium metals were introduced into the upper Salmon valley when the bench pay streak originated than at a later time when the pay streak of the valley floor was being formed. A possible corollary of the second explanation is that the low-iridium metals occurred mainly at higher horizons in the original lodes.

\section{Placer gold}

The occurrence of gold may be tabulated in two ways that have quite different meanings. The amount of gold recovered from each claim can be shown as a percentage of the total gold recovered from the pay streak, or the amount may be stated as a percentage of the precious metals recovered from each claim. Both these distributions, listed respectively as A and B, are shown in table 26 . The distribution $A$, charted as figure 13 , should have a greater genetic significance.
Tabulation A displays a number of anomalous features. One of these is the maxima shown for Discovery claim and claims 3B, 4B, and 7B. Oddly these maxima correlate closely with the maxima for the production of platinum metals, as shown in figure 10. It will be remembered that gold is scarce in the valley of Platinum Creek and its tributaries, and therefore the maximum on Discovery claim cannot be a result of enrichment from that source. Moreover, a genetic relation between gold and the platinum metals is not believed to exist. The only reasonable explanation for the three cited maxima is that they represent enrichment in gold from eastern tributaries of the Salmon River, such as Medicine Creek and Snow Gulch or streams antecedent to these, that were eroding outwash deposits in their headwaters. It will be remembered that the two pay streaks were at the same bedrock level on and adjacent to claim $4 \mathrm{~B}$, and so enrichment from the

TABLE 26.-Distribution, in percent, of gold by claims and units in two pay streaks, valley of Salmon River

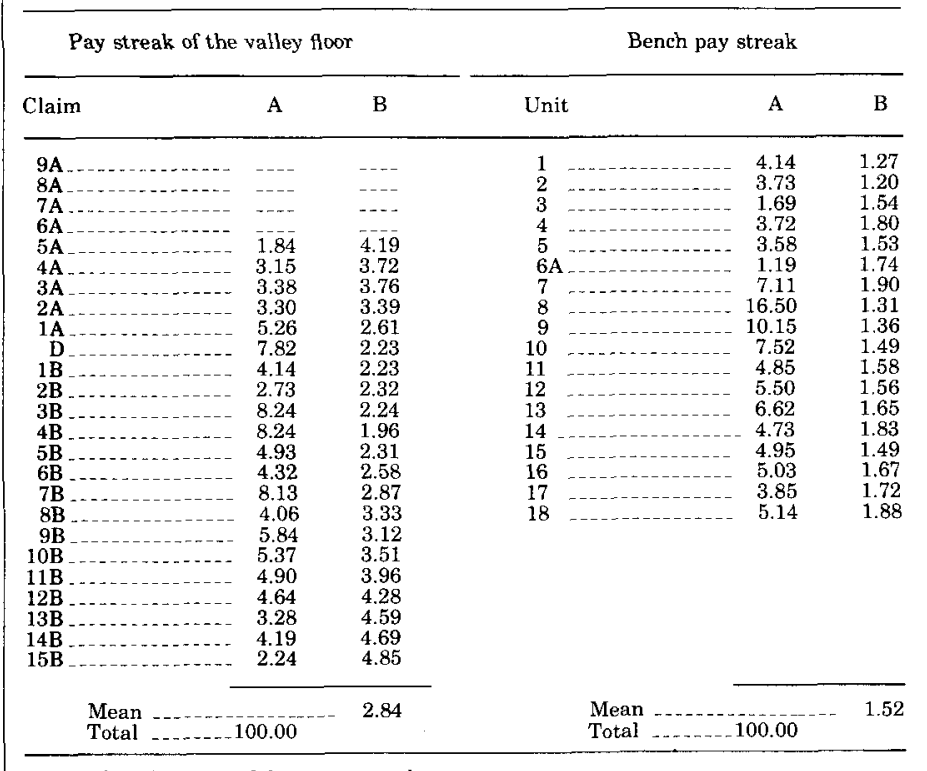

A. Total gold recovered from pay streak.

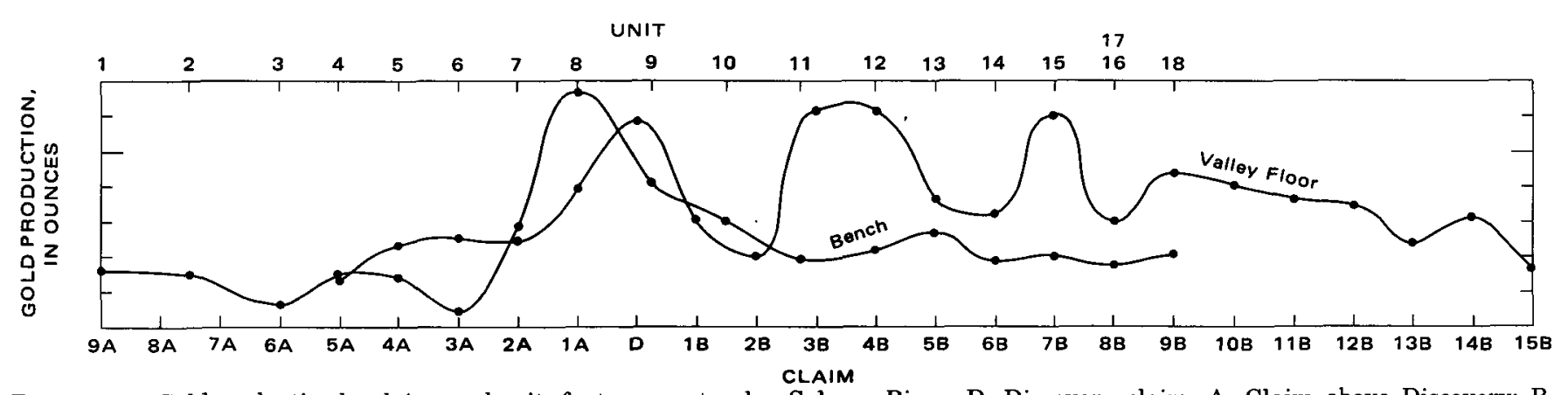

FIGURE 13.-Gold production by claims and units for two pay streaks, Salmon River. D, Discovery claim; A, Claim above Discovery; B, Claim below Discovery. 
bench pay streak, both in gold and the platinum metals, could have occurred at that site. Either or both such enrichments are suggested as a reason for the maxima in gold on claims $3 \mathrm{~B}$ and $4 \mathrm{~B}$, but only lateral stream enrichment could obtain for claim $7 \mathrm{~B}$.

A second anomaly is the high value in gold at the south end of the pay streak of the valley floor, as compared with that at the north end. Ordinarily the precious metals become progressively finer grained and scarcer downstream from their real or proximate source. No data are available on the granularity of the gold, but contrary to the usual distribution, it becomes more plentiful downstream. The uppermost (northern) four claims contain 11.67 percent of the gold, whereas the lowermost (southern) four claims contain 14.35 percent of the gold. The physiographic history of the Salmon River is long and complex and is imperfectly understood; only such events for which there are cogent proofs are chronicled. But the cited anomaly suggests a startling and unprovable hypothesis involving a reversal in the flow of this river at some time in the remote past. If the reversal occurred, it must have occurred as a result of an ice dam of Kansan age in the valley of the Kinegnak River at an early stage in the development of the pay streak, possibly during the Yarmouth interglacial stage. Thus the Salmon River could have eroded outwash deposits at the southern end of its valley. This course of events is proposed as a remote possibility for which no evidence can be offered.

The distribution of gold in the bench pay streak is likewise anomalous. The overall content of gold is about 46 percent less than that in the pay streak of the valley floor. This is understandable, for the gold of the bench pay streak was concentrated from unsorted moraine, whereas the gold in the valley floor was derived from outwash deposits and was already partly concentrated before these deposits were formed and subsequently eroded. But there are pronounced maxima in the content of gold in units 8 and 9 , opposite creek claim $1 \mathrm{~A}$ and Discovery claim, and to a much smaller degree on unit 13, opposite creek claim 4B. The explanation for these maxima must be enrichment from west-flowing tributaries of the Salmon River that were eroding outwash deposits. Tabulation B, however, shows a content of gold that is sensibly constant throughout the length of the pay streak. The bench pay streak, like the pay streak of the valley floor, was richest in platinum metals in its median zone and leaner at both ends; no explanation can be offered for why the gold should be similarly distributed.

\section{Alluvial concentrates}

The accessory minerals of the country rock are released from their bedrock sources by weathering and after stream transportation are concentrated in alluvial deposits; the character, distribution, and amounts of these minerals constitute significant data that bear upon their origins and upon the physiographic processes whereby they were concentrated. A large volume of accessory or semiheavy minerals is recovered with the platinum metals; these consist mainly of magnetite but include considerable amounts of ilmenite and chromite and smaller amounts of other rock-forming minerals. Forty samples of such alluvial concentrates were collected within the Goodnews Bay district, and the locations of these are given herewith.

Localities of samples of alluvial concentrates

[Asterisk indicates sample is in table 27]

1. 66A-Mt1* Concentrates from two pans of fractured and decomposed bedrock at a site on bench pay streak east of the lower end of claim 2A, Salmon River.

2. 66A-Mt4 Concentrates from two pans of decomposed bedrock at a site on bench pay streak east of the upper end of claim 2A, Salmon River.

3. $66 \mathrm{~A}-\mathrm{Mt} 6^{*}$ Concentrates from three pans of an alluvial red clay in the overburden overlying bedrock at a site on bench pay streak east of the upper end of claim 1A, Salmon River.

4. 66A-Mt7 Concentrates from dredge cleanup in pay streak of valley floor, claim 12A.

5. 66A-Mt8 Concentrates from one and one-half pans of stream gravels of Dowry Creek about 100 feet upstream from the automobile road to Platinum.

6. 66A-Mt9* Concentrates from one pan of the overburden about 60 feet thick, about 20 feet below the surface, at a site on bench pay streak east of the center of claim 8A, Salmon River.

7. 66A-Mt10 Concentrates from two pans of stream gravels at the upper end of the pay streak on Squirrel Creek.

8. 66A-Mt28 Concentrates from two pans of stream gravels of Squirrel Creek about halfway between the upper end of the pay streak and the junction with Platinum Creek.

9. $66 \mathrm{~A}-\mathrm{Mt} 2$ $^{*}$ Concentrates from one pan of the sand and gravel at the site of the "mud hog" operation on the bench pay streak east of claim 4B, Salmon River.

10. 66A-Mt30 Concentrates from one and one-half 
pans of stream gravels of Clara Creek about 100 feet upstream from the automobile road to Platinum.

11. 66A-Mt31 Concentrates from a cleanup of the "mud hog" at a site on bench pay streak east of claim 4B, Salmon River.

12. 66A-Mt32 Concentrates from one pan of stream gravels of McCann Creek, a tributary of the Smalls River, about 100 feet upstream from the automobile road to Platinum.

13. 66A-Mt33 Concentrates from one pan of stream gravels on Fox Gulch about 150 yards above its confluence with Platinum Creek.

14. 66A-Mt34 Concentrates from three-quarters pan of gravels from Platinum Creek about 150 yards above junction with Fox Gulch.

15. 66A-Mt35* Concentrates from one pan of stream gravels sampled about one-quarter mile upstream from the mouth of McCann Creek on the Smalls River.

16. 66A-Mt36 Concentrates from one pan of stream gravels sampled about 1,000 feet east of the eastern limit of the bench pay streak on Medicine Creek, an eastern tributary of the Salmon River.

17. 66A-Mt37 Concentrates from one-half pan of fractured shaly bedrock about 6 feet below its upper surface at a site near the northern limit of the bench pay streak and about 400 feet east of this pay streak, valley of the Salmon River.

18. 66 $\mathrm{A}-\mathrm{Mt} 38^{*}$ Concentrates from three-fourths pan of yellowish gravelly material at east side of northern limit of bench pay streak, valley of Salmon River.

19. 66A-Mt39 Concentrates from one-third pan of grayish gravels a short distance west of sample 66A-Mt38 at northern limit of the bench pay streak, Salmon River.

20. 66A-Mt40* Concentrates from two pans of outwash gravel at a bluff 30 feet high along the east side of the valley of the Salmon River about 400 yards upstream from the mouth of Happy Creek.

21. 66A-Mt41* Concentrates from two pans of gravel at base of a drill hole with a depth of
192 feet along the north side of the road to Platinum about 1.6 miles from Kuskokwim Bay, between Seattle Creek and the Smalls River.

22. 68A-Mt1* Concentrates from one pan of yellow mud from a drill hole at a depth of 60 feet in an alluvial section of 122 feet in a line of drill holes in the southern half of the Olson bench claim, valley of the Salmon River.

23. $68 \mathrm{~A}-\mathrm{Mt} 2 *$ Concentrates from one pan of gravel from a drill hole at a depth of 25 feet in an uppermost stratum of gravel 30 feet thick in a second line of drill holes in the southern half of the Olson bench claim, valley of the Salmon River.

24. 68A-Mt3* Concentrates from one pan of gravel from a drill hole at a depth of 60 feet in an uppermost stratum of gravel 72 feet thick in a third line of drill holes in the southern end of the Olson bench claim, valley of the Salmon River.

25. 68A-Mt4* Concentrates of several pans from an entire drill hole on the Hannah bench claim, valley of the Salmon River.

26. 69A-Mt3 Concentrates from one pan of bedrock at the bottom of drill hole 26 , line 1 N., at a depth of 130 feet on Alice Association bench claim, valley of the Salmon River.

27. 69A-Mt5* Concentrates from jigs, dredge cleanup, and pay streak of valley floor, claim 11B.

28. 69A-Mt6* Concentrates of several pans from an entire drill hole with a depth of 140 feet, hole 20 line $1 \mathrm{~N}$,, on Alice Association bench claim, valley of the Salmon River.

29. 69A-Mt7* Concentrates from three-fourths pan of mud and angular fragments of bedrock taken about 4 feet above bedrock in hole 28 , line $1 \mathrm{~N}$., which had a depth of 136 feet, on Alice Association bench claim, valley of the Salmon River

30. 69A-Mt8 Concentrates from cleanup of dragline excavator from site on Platinum Creek just above the mouth of Squirrel Creek.

31. 69A-Mt9* Concentrates from an unknown number of pans recovered from 
Pacific beach a short distance south of the narrow stretch of beach caused by the promontory of Red Mountain. Sample submitted by Edward Olson.

32. 69A-Mt10* Concentrates from one and one-fourth pans of outwash gravel at approximately the same site but not the same stratum as sample 66A-Mt40.

33. 69A-Mt11* Concentrates from one and one-half pans of morainal or outwash gravel taken from a gravel pit on the east side of the road to Platinum about 2,000 feet south of the divide between the Salmon River and the Smalls River.

34. 69A-Mt14* Concentrates from dredge cleanup in pay streak of valley floor claim 11B (below Discovery).

35. 69A-Mt15* Concentrates from one pan recovered from Pacific beach about 1 mile north of the mouth of the Salmon River. Sample submitted by Joseph F. Fisher.

36. 69A-Mt16* Concentrates from two pans of outwash gravels at a sea cliff facing Kuskokwim Bay about 11/2 miles north of the mouth of the Salmon River; submitted by Joseph F. Fisher.

37. 69A-Mt17* Concentrates from one pan of outwash gravels at a sea cliff facing Kuskokwim Bay about $2 \frac{1}{2}$ miles north of the mouth of the Salmon River; submitted by Joseph F. Fisher.

38. 69A-Mt18* Concentrates of several pans from an entire drill hole on the bench pay streak south of Happy Creek; panned and submitted by Joseph F. Fisher.

39. 72A-Mt1 Concentrates from dredge cleanup in bench pay streak on Fourth of July bench; submitted by Joseph F. Fisher.

40. 72A-Mt2 Concentrates from an entire drill hole, no. 27 line 15 , a short distance downstream from Happy Creek; submitted by Joseph F. Fisher.

Of the samples listed, 14 were taken from surficial stream gravels, 5 from surficial outwash deposits, 6 from the cleanups of mechanical excavators, 9 from drill holes, 4 from bedrock, and 2 from beach sands. It should be stressed that regardless of the methods of recovery, the percentages of accessory minerals in alluvial deposits can seldom be ascertained, as the requisite data are seldom available. The samples panned from surficial gravels are inherently low in the heavier accessory minerals that lie close to bedrock. If a sample is taken from the cleanup of a dredge or dragline excavator, neither the total weight of the concentrates nor the volume of the mined ground is generally known to the sampler. And unless a drill hole is cased from top to bottom, and this is seldom done, the total volume is not accurately known. Moreover, the actual ratios of the accessory minerals to one another is indeterminate, as the sampling of surficial deposits necessarily yields more minerals of low than of high density; in a dredge or dragline excavator, where sluices or jigs are used, most of the lighter accessory minerals are eliminated. Samples from hardrock or residual deposits comprise both accessory minerals of alluvial origin, introduced into crevices of the bedrock, and those indigenous to the hardrock. Finally, an important factor is the skill of the sampler in the art of panning. A miner in search of the precious metals can clean a pan of gravels in a few minutes. If a high recovery of accessory minerals is desired, the job may take a skilled panner 30 minutes or more. If much plastic or semi-indurated clay is present, a much longer time will be needed. Despite these obvious shortcomings, alluvial concentrates have cogent values that depend partly upon the methods of recovery and partly upon the uses for the resulting data.

The following magnetic methods have been used in separating the accessory minerals. The concentrates are spread evenly and thinly on a large sheet of paper so that the various minerals do not overlap. Magnetite is removed without the inclusion of other minerals by passing a small alnico horseshoe magnet over the concentrates at a distance of $1 / 4-1 / 2$ inch. It is necessary to lift the magnetite in a single operation because grains of magnetite placed in a strong magnetic field often become miniature magnets that can adhere in clumps, enclosing other nonferromagnetic minerals. Hence the separation of magnetite, either in bulk or in multiple operations, is not feasible.

The principal accessory minerals, other than magnetite, are ilmenite, chromite, and olivine; other minerals are present in smaller amounts. Approximate separations into three additional fractions are made by using two other alnico horseshoe magnets of increasingly higher gauss, utilizing the same technique as for magnetite except that the separates are obtained by contact. Because the magnetic susceptibility and density of ilmenite are only slightly greater than for chromite, the first of the three fractions is made up of ilmenite, chromite, and a small part of the olivine. The second fraction consists of olivine and other minerals of similar magnetic susceptibility, including epidote and 
garnet, if present. The third fraction includes the remaining minerals that are so weakly paramagnetic or diamagnetic that they are not held by the strongest alnico magnet. This degree of separation and the weights of the fractions usually suffice for the recognition of the various minerals and for an approximate determination of their abundance. For special purposes, some of these fractions are sieved into 14 sizes.

The samples taken from stream gravels are mainly of local interest, as they represent the minerals derived from the Red Mountain ridge, excepting those from Medicine Creek and the Smalls River. The dredge concentrates, excepting 72AMt-1 from the bench pay streak, represent the pay streak of the valley floor of the Salmon River; sample 69AMt-8 is from the closely related pay streak of Platinum Creek. The three dredge samples from the Salmon River and the dragline sample from Platinum Creek consist mainly of minerals of local origin from which most of the lighter accessory minerals have been eliminated. The samples of the bench deposits, including 72AMt-1, consist largely of minerals from reworked morainal deposits and therefore contain a higher proportion of alien minerals. Some of the finer grained minerals, both local and alien, have penetrated deeply into cracks and crevices of the shattered bedrock of the bench. For these reasons, the bench concentrates are of special interest.

Magnetite, owing to its abundance, ease of separation, and lack of alteration, is perhaps genetically the most useful mineral in this collection. Under tropical or subtropical conditions, magnetite alters readily to other minerals. In the southern United States, notably in Florida, the alluvial concentrates contain little or no magnetite, and even ilmenite is partly or wholly altered to arizonite or to leucoxene. Under the arctic and subarctic conditions that must have prevailed in Alaska during the Pleistocene glaciations and interglaciations, magnetite appears to have been practically immune to surficial alteration.

The mean percentages of the iron ores and other minerals of the concentrates for 23 samples, given in table 27, show the ratios of magnetite to ilmenite (including small amounts of chromite and olivine) to be highly variable. Probably the most significant ratio is that shown by the dredge and dragline concentrates, about 7.5:1, and this may be taken as the mean abundance of these two minerals in the pay streak of the

TABLE 27.-Mean mineral content, in percent, of alluvial concentrates

\begin{tabular}{|c|c|c|c|}
\hline Type of deposit & Magnetite & Ilmenite & Other \\
\hline Stream grave & 53.4 & 35.1 & 11.5 \\
\hline Dredge and dragline sample & 87.3 & 11.7 & 1.0 \\
\hline Bench pay streak deposit & 66.6 & 29.5 & 3.9 \\
\hline Decomposed bench bedrock & 48.7 & 47.9 & 3.4 \\
\hline Glacial outwash deposit & 37.9 & 49.0 & 13.1 \\
\hline Beach sand & 75.5 & 21.1 & 3.4 \\
\hline
\end{tabular}

valley floor of the Salmon River. One sample of this group, taken from a dragline cleanup on Platinum Creek just above the mouth of Squirrel Creek, showed a ratio of 7.9:1. In contrast, the mean ratio of magnetite to ilmenite from upper Platinum, Squirrel, Dowry, Clara, and McCann Creeks was only 2:1. The cause of this discrepancy is uncertain, but it may result from an abnormally high content of chromite.

The least magnetic fraction contains small amounts of minerals with densities greater than 3.3, mainly zircon, corundum, rutile, garnet, pyrite, and cinnabar, as well as any precious metals of the concentrates. Most of the minerals of this fraction have densities less than 3.3; they include quartz, feldspars, chert, serpentine, chlorite, pyroxene and amphibole, dolomite, tourmaline, apatite, and sphene, approximately in the order named. Of the heavier constituents, all but zircon, rutile, and garnet are regarded as largely of local origin; zircon, more common than the other two, is considered to be a critical index of alien origin. It is essentially absent in the concentrates of the stream valleys and is most prevalent in the outwash deposits, though present in concentrates of the bench pay streak, the Smalls River, and in smaller amounts in the dredge concentrates of the Salmon River. Of the lighter minerals, only tourmaline and sphene are considered to be of foreign origin.

Cinnabar in very small amounts was first recognized in the concentrates from the bench, but small amounts were later found in the dredge concentrates from the valley floor. Cinnabar was first thought to be an alien mineral, particularly as deposits of this mineral are present in the Kuskokwim valley and in the vicinity of the Tikchik Lakes. As it seemed doubtful that a mineral as soft as cinnabar could have survived glacial transport from these places, it was concluded that the cinnabar of the Goodnews placers was of local origin, derived either from the perknitic rocks of Susie Mountain or from late hydrothermal veinlets in the dunite. Collateral evidence is the presence of cinnabar in the platinum placers of the Ural Mountains, as recorded by Duparc and Tikonowitch (1920), and in the placers of the Goenoeng-Lawack district of Borneo, as recorded by Mertie (1969, p. 74). Of interest mineralogically is the presence of minute amounts of native mercury in some of the dredge concentrates, though this element is not utilized in the recovery of the precious metals. Native mercury has also been identified in primitive alluvial deposits in the Kuskokwim valley in the vicinity of the cinnabar deposits.

The platinum metals of this area have been shown to be closely associated with chromite, but it is known from the work done on numerous samples by W. C. Overstreet and associates of the U.S. Geological Survey 
that the magnetite also contains small quantities of these metals. The tenor of platinum metals in the magnetite has been found to be a fifth or less of that present in the chromite. Another peculiarity of this magnetite is that practically all samples submitted for spectrographic analysis showed about 1 percent chronium. Inasmuch as ferric iron makes up 48.24 percent of the molecule of magnetite, this increment constitutes an ionic replacement of about 2 percent chromium. It is possible that a part of this tenor in chromium represents an inhomogeneity, that is, an inclusion of chromite. The magnetite also contains about 0.3 percent manganese and smaller amounts of vanadium, zinc, nickel, and cobalt, in the order named. Traces of 18 other base elements have been identified.

\section{PLATINUM LODES}

All the platinum metals of the Goodnews Bay district have been derived from a mass of dunite, partly altered to serpentinite, that forms the ridge west of the upper valley of the Salmon River. All the headwater tributaries of the Salmon River flowing eastward from this ridge have fluvial deposits that are platinum bearing, and McCann Creek, draining northeastward to the Smalls River, also carries platinum metals. No other tributaries of the Salmon River are platinum bearing. The virtual absence of platinum metals in the streams draining westward from the Red Mountain ridge is believed to have resulted from their removal by glacial scouring, although it is possible that the bedrock sources of the platinum metals may have been localized in the eastern flank of the ridge.

No workable lodes have yet been found in the dunite of the Red Mountain ridge. Two possible explanations are offered for the absence or paucity of lodes at or near the present surface. One is that all or most of the lodes have been almost or entirely eroded. An experiment bearing upon this interpretation has been made by the Goodnews Bay Mining Co. In 1965, a portable washing plant, with an adequate supply of water in drums, was transported to the top of the Red Mountain ridge near the head of Squirrel Creek, and the residual material at that site was sampled and sluiced. Some grains of platinum and traces of gold were recovered. The results suggest, but do not constitute, definite proof that the platinum was of residual origin; in fact, the presence of gold, which is believed to be derived from an ancient morainal deposit, suggests that the platinum was not derived from bedrock near the present surface and that both metals were of ancient origin.

A second and more probable explanation is that most of the platinum metals were widely and sparsely distributed in the dunite and that the detrital metals have accumulated very slowly over a very long period of time, that is, since the beginning of the Pliocene Epoch, when the dunite is believed to have been first bared to erosion. This explanation renders unlikely the discovery of any large volume of workable ore; it does not preclude the possibility of finding small local concentrations of high-grade ore similar to those found in the dunites of the Ural Mountains.

The crest of the Red Mountain ridge, throughout its length, is characterized by a fairly flat surface. It is possible that along this crest platinum metals have accumulated residually over a long period of time and have remained undisturbed except where transected by headwater fluvial gulches. The experimental prospecting of residual materials atop the ridge by the Goodnews Bay Mining Co. suggests this possibility. Such deposits, if they exist, have not been concentrated by stream action and therefore cannot be high-grade ores. But if some method could be devised to move these residual deposits into the lower valleys where sluice water is available, they might qualify as low-grade but workable ores.

The original lodes, even if their exact sites have not been determined, have some interesting aspects that have been gleaned from the distribution of the platinum metals in the derived placers. The metals found in the valleys that drain the Red Mountain ridge show unmistakably that the composition of the lodes, and particularly the ratio of the major to the minor alloy, is variable. A very small part of these variations may result from the presence of certain platinum minerals, including cooperite and minerals intergrown with the alloys, such as laurite, sperrylite, mertieite, and other species as yet unnamed. Also the two alloys may vary somewhat in their compositions. But the principal variations in composition are dependent almost entirely upon the proportions of the two alloys.

A striking variation in the composition of the lodes has been recognized in the platinum metals recovered from the placers of the western headwater tributaries of the Salmon River. Mining on these streams has shown that the content of platinum increases from Platinum Creek northward and, conversely, that the contents of iridium, osmium, ruthenium, and rhodium decrease in the same direction. The magnitude of these changes is presented in table 20 and is also charted in figure 14, where the abscissas are taken as the air distances from Fox Gulch to the heads of Squirrel Creek, Boulder Creek, Dowry Creek, and Clara Creek, that is, 1.1, 1.6, 2.55 , and 2.9 miles, respectively.

Platinum and iridium, owing to their larger volumes, are genetically the two most significant elements. For the same reason, variations in composition introduced by different analysts are much less likely to show. Neither the platinum nor the iridium curves are linear, 


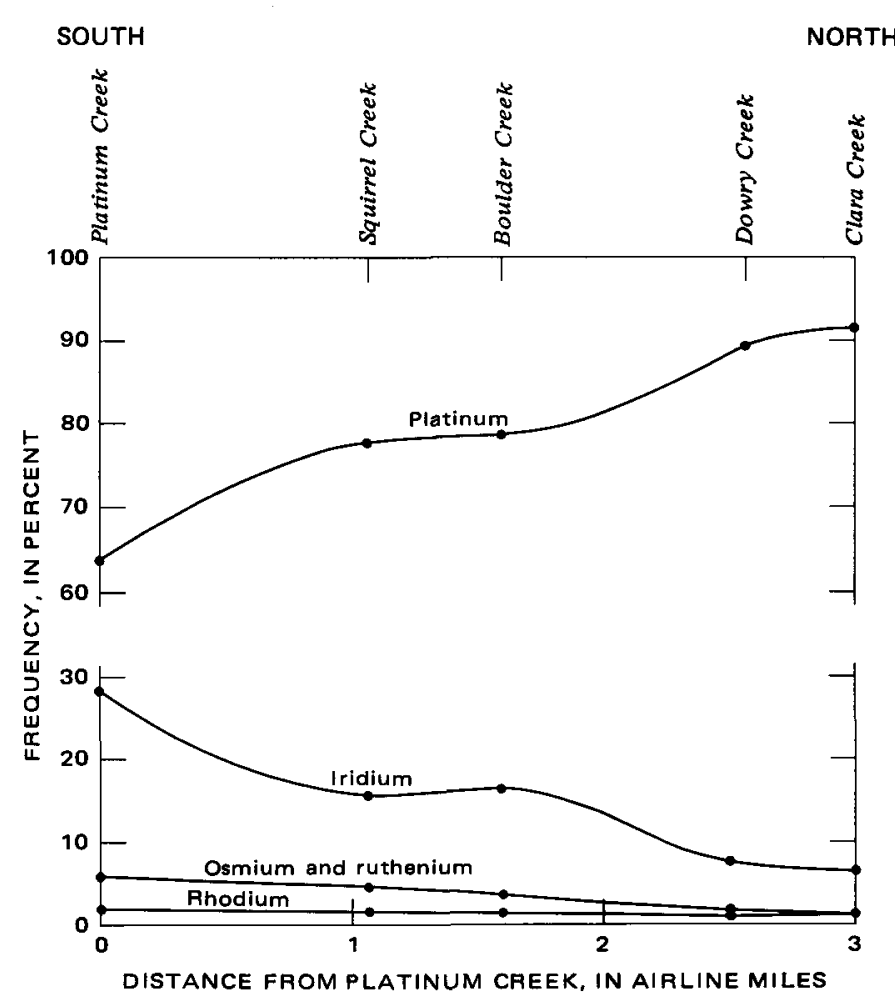

Figure 14.-Variation in composition of platinum metals from streams that drain Red Mountain ridge.

although they appear to have almost a reciprocal relation. The content of platinum increases about 43 percent and the content of iridium decreases about 78 percent from the upper valley of Platinum Creek to Clara Creek. The content of osmium plus ruthenium decreases about 82 percent, with a curve that is almost linear. From this result, it is inferred that osmiridium also increases linearly from south to north. Therefore if a curve for the principal alloy could be charted, it would be expected to be nearly linear. Rhodium decreases about 38 percent from south to north, thus suggesting that it is more closely related to osmiridium than to the principal alloy; that is, the osmiridium should contain more rhodium (by weight) than the principal alloy. This conclusion is confirmed in table 13 . No inferences can be drawn from the percentages of palladium, as the analyses from Dowry and Clara Creeks are not regarded as dependable in every respect.

Another possible variation in the platinum metals with distance is the granularity or sizes of the metallic grains in the lodes. Such a variation cannot be substantiated, as no sieving analyses were made of the products recovered from the western headwater tributaries of the Salmon River. If such a variation exists, it would have to be recognized in the metals recovered from the two pay streaks of the Salmon River above the mouth of Platinum Creek. Unfortunately, this is not possible, as the platinum metals in the upper stretches of the two pay streaks have been considerably intermixed by geologic processes heretofore described; this condition is further complicated by the fact that the metals of the two pay streaks were derived from lodes that existed at different erosional levels on Red Mountain. Only two facts are definitely known. First, the mean granularity of the metals in the bench pay streak is smaller than that in the pay streak of the valley floor. And second, the metals that issued from the valley of Platinum Creek, as heretofore shown, were coarser grained than those from the valley of the Salmon River upstream from the mouth of Platinum Creek. The favored interpretation is that the metals deposited in the bench pay streak were derived from the lodes that were first barred to erosion and that these higher horizons in the lode system yielded platinum metals of smaller granularity. On the other hand, it seems possible that within the lower horizons of the lode system, which yielded the metals in the pay streak of the valley floor, the granularity decreased from south to north. The curves of figures 10 and 12 will not serve to validate these interpretations owing to obvious intermixing of metals of the two pay streaks, but two curves of these figures show at least that the percentage of grains smaller than $0.42 \mathrm{~mm}$ in the bench pay streak is much larger than the corresponding percentage for the pay streak of the valley floor.

The original size of the lode system and the tenor of the lodes in platinum metals are problems that have no explicit solutions, yet it may be of some value to venture certain approximations. The ultrabasic rocks that constitute the Red Mountain ridge were probably barred to erosion at the beginning of the Pliocene Epoch, about 5 million years ago. The shape of the original mass of dunite is unknown, but the contacts suggest that it may have had the general form of a triaxial ellipsoid, with a major axis trending N. $20^{\circ} \mathrm{E}$., a median axis tilted slightly westward, and a near-vertical minor axis plunging steeply $\mathrm{S} .70^{\circ} \mathrm{E}$. This intrusive body may either have been emplaced in this position or it may subsequently have been tilted from some earlier position. For maximum simplicity in computation, the ellipsoid is considered to be vertically emplaced. The present surficial contact with the adjacent country rock is arbitrarily interpreted as an ellipse that delimits the base of an eroded segment of the ellipsoid.

The rate of denudation for the United States has been estimated by Dole and Stabler (1909) to be 1 inch in 730 years, or approximately 0.0001 foot per year. This estimate, though made many years ago, was carefully prepared and is believed still to be of the right order of magnitude. On this basis, the altitude of the Red Mountain ridge may have been lowered about 500 feet 
since the dunite was first barred to erosion at the beginning of the Pliocene Epoch. Assuming that half the intrusive mass has been removed by erosion, the present outcrop may be used to obtain the dimensions of two semiaxes of the ellipsoid. The length of the intrusive, including a small part north of the Smalls River, is 6 miles, whence the major semiaxis is 3 miles. By mechanical integration, the surficial area was found to be 7.3 square miles. The area of an ellipse is $A=\pi a b$, whence the average median semiaxis is found to be

$$
b=\frac{A}{\pi a}=\frac{7.3}{3 \pi}=0.775 \text { mile. }
$$

From this, the dimensions are

$$
\begin{aligned}
& a=\text { major semiaxis }=3.0 \text { miles } \\
& b=\text { median semiaxis }=0.775 \text { mile, and } \\
& c=\text { minor semiaxis }=500 \text { feet }=0.0947 \text { mile. }
\end{aligned}
$$

The volume of half of a triaxial ellipsoid is given by

$$
V=\frac{2}{3} \pi a b c \text {. }
$$

Substituting the values given for $a, b$, and $c$, we obtain

$V=2.0944 a b c=0.461$ cubic mile and

$V=(0.461)=(1,760)^{3}$ cubic yards.

The platinum metals contained in the eroded half of the ellipsoid are estimated to have amounted to one million troy ounces. This includes metals mined, metals lost in mining, metals not yet mined, and metals permanently lost by erosion. This estimate may in fact be low, but it seems as large as warranted by the facts now at hand. The derived mean tenor is therefore $1,000,000 /(0.461) \times$ $(1,760)^{3}=0.00040$ troy ounce, or about 0.19 grain per cubic yard. The tenor of the Nishniy-Tagil dunite of the Ural Mountains was computed by Duparc and Tikonowitch (1920) to be 0.13 grain per cubic yard.

Another check depends upon two analyses made by E. T. Erickson, U.S. Geological Survey. The first analysis, made of a composite sample of dunite taken at regular intervals from the south to the north end of the Red Mountain ridge, showed a tenor of 0.27 percent of $\mathrm{Cr}_{2} 0_{3}$ or 0.4 percent chromite. The second analysis, made of a random sample of chromite pebbles taken from a cleanup on Fox Gulch, where this mineral is unusually abundant, showed a tenor of 0.05 troy ounce of platinum metals per ton of chromite. Combining these two analyses and taking the density of dunite as 3.3 , it is found that a cubic yard of dunite contains 0.27 grain of platinum metals. These two tenors, that is, 0.19 and 0.27 grains platinum metals per cubic yard of dunite, may therefore be taken as the limiting values. It is conceded that the tenors to be expected in prospecting may be higher than these, as the tenors in the uppermost horizons of the dunite must have been much lower than the mean value. But even if the mean tenor were as great as 1 grain per cubic yard, the platinum metals contained would have a value of only about 47 cents per cubic yard or about 17 cents per ton with the value of platinum at $\$ 225$ an ounce (as of April 1974). Many years ago The Alaska-Juneau Co., by handling very large tonnages, was able to mine hardrock with a tenor of a dollar per ton in gold, but that would no longer be possible.

The prospecting for lodes requires that these results be carefully scrutinized. There is no evidence that the platinum metals were distributed uniformly within the dunite, in either a horizontal or a vertical sense; ample proof has been given that the ratios of the two alloys differ from south to north. The richness of the placers in the valleys of Squirrel Creek and Fox Gulch, as compared with those of Clara Creek, indicates an uneven horizontal distribution, and this is corroborated by the paucity of platinum metals in the intervening streams. And metals with the high density of the platinum group are not likely to have been distributed uniformly in a vertical sense. The importance of such a vertical concentration cannot be appraised but is a factor to consider. If all the known facts are considered, the area at or near the heads of Squirrel Creek and Fox Gulch appears to be the best site for prospecting for lodes. It should be kept in mind that the dunite of the Red Mountain ridge is strikingly similar to that of the Nishniy-Tagil area of the Ural Mountains, where small bodies of platinum-bearing chromite were found, ranging in length from 1 to 400 feet. The highest grade of such aggregates was the "Krutoy Log lode," a mass of chromite 2 metres in length that yielded 965 ounces of platinum metals. In conclusion, it may be said that the dunite of Red Mountain is not a favorable site for the discovery of any large body of low-grade but workable ores of the platinum metals. It is possible that some small concentrations of high-grade ore may be located.

\section{SELECTED REFERENCES}

Cross, Whitman, Iddings, J. P., Pirrson, L. V., and Washington, H. S., 1903, Quantitative classification of igneous rocks: Univ. Chicago Press, p. 187-230.

Desborough, G. A., Finney, J. J., and Leonard, B. F., 1973, Mertieite, a new palladium mineral from Goodnews Bay, Alaska: Am. Mineralogist, v. 58, nos. 1 and 2, p. 1-10.

Dole, R. B., and Stabler, Herman, 1909, Denudation: U.S. Geol. Survey Water Supply Paper 234, p. 78-93.

Duparc, C. L., and Tikonowitch, M. N., 1920, Le platine et les gites platiniferes de l'Oural et du Monde: Gèneve Soc. Anonyme des Editions Sonor, 542 p.

Ericson, D. B., and Wollin, Goesta, 1968, Pleistocene climates and chronology in deep-sea sediments: Science, v. 162, no. 3859 , p. 1227-1234.

Ford, L. A., 1964, Platinum alloy permanent magnets: Platinum Metals Rev., v. 8, no. 3, p. 82-90. 
1966, Cobalt-platinum alloy magnets: Platinum Metals Rev., v. 10 , no. 3 , p. $84-86$.

Harrington, G. L., 1921, Mineral resources of the Goodnews Bay region, Alaska: U.S. Geol. Survey Bull. 714, p. 207-228.

Hoare, J. M., and Coonrad, W. L., 1961a, Geologic map of the Goodnews quadrangle, Alaska; U.S. Geol. Survey Misc. Geol. Inv. Map 1-339, scale 1:250,000.

1961b, Geologic map of the Hagemeister Island quadrangle, Alaska: U.S. Geol. Survey Misc. Geol. Inv. Map I-321, scale 1:250.000.

Johnson, Matthey and Co., Ltd., 1972, Physical properties of the platinum metals: Platinum Metals Rev., v. 16, no. 2, p. 59.

Leonard, B. F., Desborough, G. A., and Page, N. J, 1969, Ore microscopy and chemical composition of laurite: Am. Mineralogist, v. 54, p. $1330-1346$.

MacNeil, F. S., Mertie, J. B., Jr., and Pilsbry, H. A., 1943, Marine invertebrate faunas of the buried beaches near Nome, Alaska: Jour. Paleontology, v. 17, p. 69-96.

Mertie, J. B., Jr., 1938, The Nushagak district, Alaska: U.S. Geol. Survey Bull. 903, 96 p. 1940a, The Goodnews platinum deposits, Alaska: U.S. Geol. Survey Bull. 918, 97 p.

1940b, Placer gold in Alaska: Washington Acad. Sci. Jour., v. 30 , no. 3 , p. $93-124$

1969, Economic geology of the platinum metals: U.S. Geol. Survey Prof. Paper 630, 120 p.

Moffit, F. H., and Mertie, J. B., Jr., 1923, The Kotsina-Kuskulana district, Alaska: U.S. Geol. Survey Bull. 745, 149 p.

Porter, S. C., 1967, Glaciation of Chagvan Bay area, southwestern Alaska: Arctic, v. 20, no. 4, p. 227-246.

Reed, Irving, 1933, Mining investigations and mine inspection in Alaska, for biennium ending March 31, 1933: Juneau, Territory of Alaska Rept., p. 103-126.

Sawin, H. A., 1938, Bucket dredge installed at Goodnews Bay, Alaska: Eng. and Mining Jour., v. 139, no. 5, p. 40-41.

Spurr, Josiah, 1900, A reconnaissance in southwestern Alaska in 1898: U.S. Geol. Survey Ann. Rept., pt. 7, p. 31-264.

Wöhler, F., 1866, Über ein neues Mineral von Borneo: Annalen der Chemie und Pharmacie, v. 139, p. 116-120. 
